Portland State University

PDXScholar

5-8-1997

\title{
Wealth for Everybody - Semantics and Structure of the Capitalist Metanarrative
}

Sylvia Hendel

Portland State University

Follow this and additional works at: https://pdxscholar.library.pdx.edu/open_access_etds

Part of the Sociology Commons

Let us know how access to this document benefits you.

\section{Recommended Citation}

Hendel, Sylvia, "Wealth for Everybody - Semantics and Structure of the Capitalist Metanarrative" (1997). Dissertations and Theses. Paper 5347.

https://doi.org/10.15760/etd. 7220

This Thesis is brought to you for free and open access. It has been accepted for inclusion in Dissertations and Theses by an authorized administrator of PDXScholar. Please contact us if we can make this document more accessible: pdxscholar@pdx.edu. 


\section{Thesis Approval}

The abstract and thesis of Sylvia Hendel for the Master of Arts in Sociology were presented May 8, 1997, and accepted by the thesis committee and the department.

Committee Approvals:

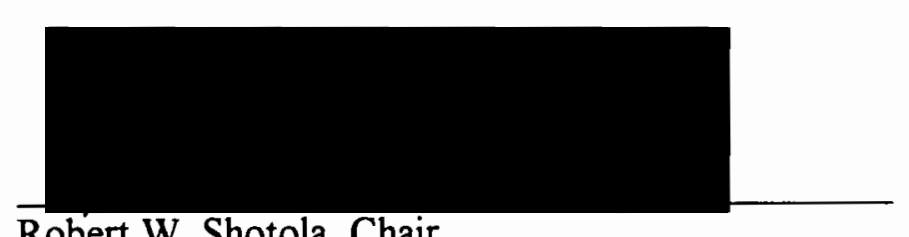

Robert W. Shotola, Chair

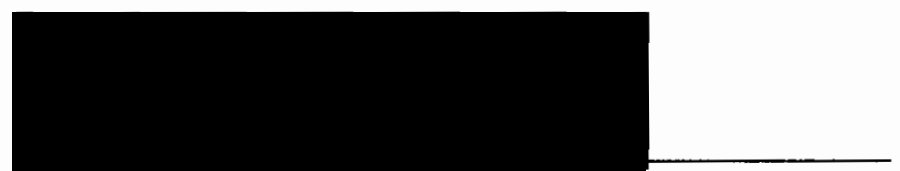

Robert C. Liebman

Michael F. Reardon

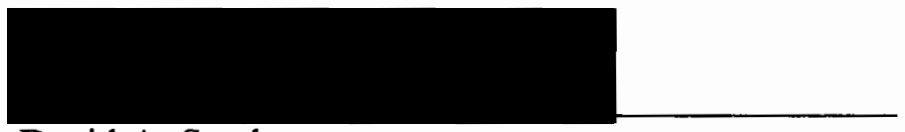

David A. Smeltzer

Representative of the Office of Graduate Studies

Department Approval:

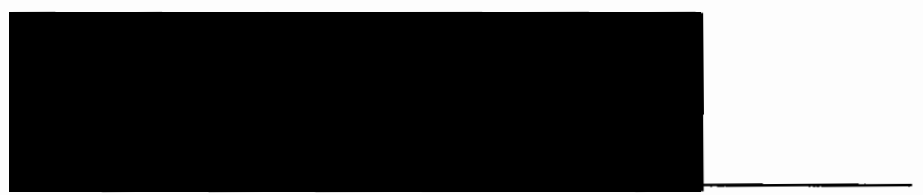

Robert W. Shotola, Chair

Department of Sociology

Accepted for Portland State University by the Library

by

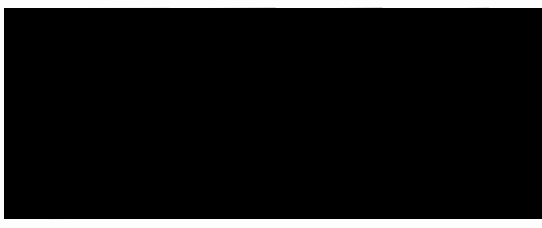

on

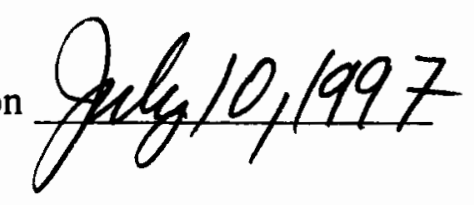




\section{Abstract}

An abstract of the thesis of Sylvia Hendel for the Master of Sociology presented May 8, 1997

Title: Wealth for Everybody-

Semantics and Structure of the Capitalist Metanarrative

In 1979 Jean-François Lyotard defined postmodernism as "incredulity toward metanarratives." One of six narratives Lyotard saw in decline was the capitalist one, which promised wealth for everybody. According to Lyotard this narrative was refuted by recurrent economic crises in the 20 th century.

This thesis examines Lyotard's statement about the decline of the capitalist metanarrative by taking the approach of the sociology of knowledge, a branch of sociology that attempts to relate ideas to the socio-historical settings in which they are produced and received.

The idea of general abundance, or the semantics, is described in othodox economic theory. Four distinct, successive phases marked major shifts regarding the idea of wealth for everybody in economics from the late 18th century onward. Two British structures and their relationship to the idea of general abundance are examined: the general economic development of the country and the economic situation of the people, and the social and economic policies in relation to the idea of general 
abundance. How did the development of the economic structure impact on the development of the idea? How did the statement of the idea influence the policies?

The findings support Lyotard's thesis claiming the decline of the capitalist metanarrative. While wealth for everybody was explicitly promised at the beginning of modern economic thought, nowadays such statements cannot be found. The examination of British economic development and policies suggests that the decline of the idea is closely related to the structural developments. Despite constant economic growth and severe efforts of the state to eliminate poverty by redistributing income and wealth, the poverty levels could never be changed significantly, hence, the promise of wealth for everybody could never be fulfilled. Therefore, the economic crises that Lyotard identified as cause for the decline of the metanarrative were periods when economic and political trends became accelerated and led to a break with, until then, prevalent policies in regard to general abundance. 


\section{WEALTH FOR EVERYBODY --}

SEMANTICS AND STRUCTURE OF THE CAPITALIST METANARRATIVE

by

SYLVIA HENDEL

A thesis submitted in partial fulfillment of the

requirements for the degree of

\section{MASTER OF ARTS \\ in \\ SOCIOLOGY}

Portland State University

1997 
The history of economics has become a nearly moribund subject in the United States, and has not failed to decline elsewhere.

GEORGE J. STIGLER 


\section{Table of Contents}

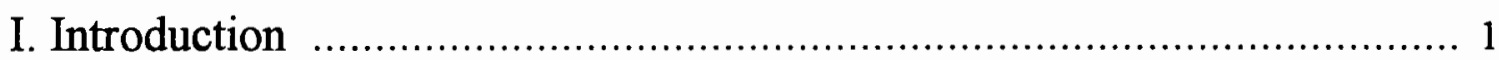

II. The Making, the Development, and the Realization of the Idea of General Abundance .................................................... 11

1. The De-Moralisation of Acquisitiveness …..................................... 11

2. Classical Political Economy (1770s-1870s) .......................................... 16

2.1 The First Industrial Revolution …....................................... 16

2.2 The Emergence of the Classical School ...................................... 20

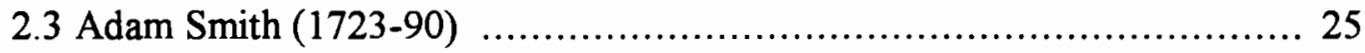

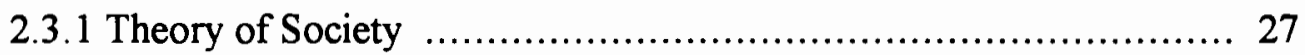

2.3.2 The Wealth of Nations ................................................. 30

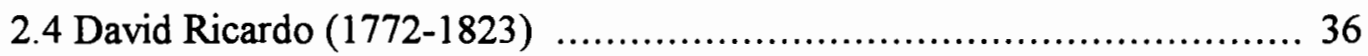

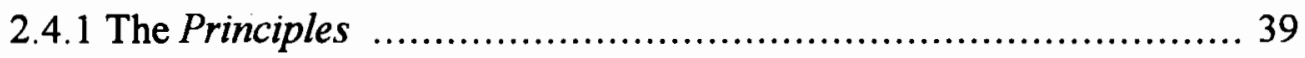

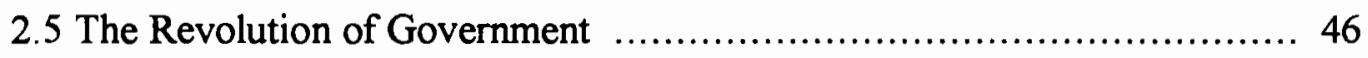

3. Neo-Classical Economics (1890s-1930s) ....................................... 54

3.1 The Victorian Boom ............................................................... 54

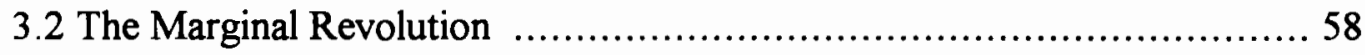

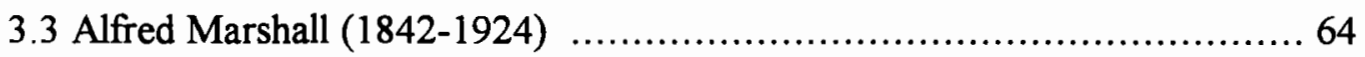

3.4 The Introduction of Collective Modern Welfare ........................... 76

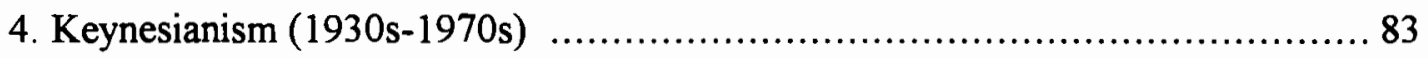

4.1 Two World Wars and the Great Depression ............................... 83

4.2 John Maynard Keynes (1883-1946) .......................................... 87

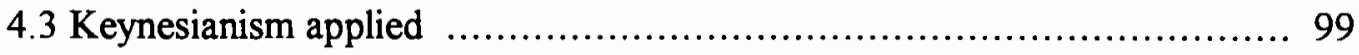


5. Monetarism, New Classical Macroeconomics, and New Keynesianism (mid-1960s-today) ..................................... 112

5.1 Much Ado about Old Ideas ................................................. 112

5.2 The Comeback of Laissez-Faire ............................................ 117

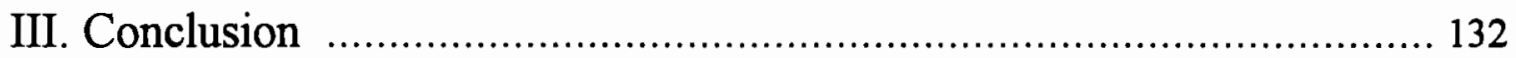

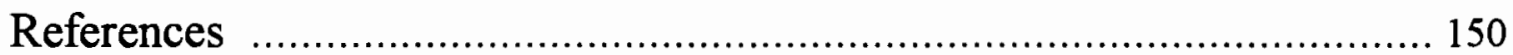


List of Tables

I The Recessions of 1974/75 and 1979-81 in Great Britain 121

$\begin{array}{ll}\text { II Distribution of Personal Income, 1949-1976/77 } & 122\end{array}$ 


\section{Introduction}

In 1979 with the publication of Le condition postmoderne Jean-François Lyotard started a discourse on postmodernity in philosophy and the social sciences. ${ }^{1}$ What makes this book special among all postmodern literature, and probably one of the most read books about postmodernity is that the philosophical "diagnosis received an interdisciplinary confirmation" (Connor 1989:6). Lyotard's definition of postmodern as "incredulity toward metanarratives" (Lyotard 1993a:XXIV) declares the postmodern condition as a generic social condition.

In Le condition postmoderne and a collection of essays, published in 1988, Le Postmoderne expliqué aux enfants, Lyotard refers to four meta- or grand narratives that have marked modernity ${ }^{2}$ : German idealism's philosophical, speculative narrative of the unity of all knowledge that produces cumulative understandings of man, nature, and society; the Enlightenment narrative of the gradual emancipation of humanity, embodied in the ideals of the French revolution; the Marxist narrative of the emancipation of humanity due to the socialization of labor; and the capitalist narrative of the enrichment

\footnotetext{
1 As Welsch $(1987,1988)$ shows, and in contrast to common understanding, the contemporary discourse about postmodernism did not start in architecture but in a literature debate in the U.S. in the 1950 s, before the discussions spilled over to architecture in the 1970s. Nowadays, there seems to be no discipline in the liberal arts and sciences that does not discuss postmodernism; it even leaves traces in disciplines like zoology, biology, forestry, geography, and medicine.

2 Lyotard gives two more examples of metanarratives: the "hermeneutics of meaning" (Lyotard 1993a:XXIII) and "the salvation of creatures through the conversion of souls to the Christian narrative of martyred love" (Lyotard 1993c:18). However, he never elaborates on these and, therefore, seems to see them as subordinate to the others.
} 
of all humanity through techno-industrial development (Lyotard 1993a:XXIII; Lyotard $1993 c: 17-18,25) .^{3}$

The function of these narratives - which cannot be fulfilled any more in advanced capitalist societies-is to

legitimate social and political institutions and practices, forms of legislation, ethics, modes of thought, and symbolics. ... they ground this legitimacy ... in a future to be brought about, that is, in an Idea to realize. This Idea (of freedom, "enlightenment", socialism, general prosperity) has legitimating value because it is universal. It gives modernity its characteristic mode: the project, that is, the will directed toward a goal. (Lyotard 1993c:50)

Nowadays there is hardly any book or article on postmodernism and postmodernity that does not refer to Lyotard's statements about the incredulity toward grand narratives. His theses are taken for granted and are viewed as proven, even though Lyotard gives only a few confuting events to verify his statements. Auschwitz, "the crime opening postmodernity" (Lyotard 1993a:19), refuted the Hegelian speculative narrative of rationality; May 1968 in Paris refuted the Enlightenment ideas of freedom, embodied in parliamentary democracy; Stalin and his gulags, Berlin 1953, Budapest 1956, Czechoslovakia 1968, and Poland 1980 refuted the emancipatory Marxist ideal; the recurrent crises in capitalist societies, e.g. in 1929, 1974-79, refute the capitalist narrative and its promise of wealth for everybody (Lyotard 1993c, 28-29).

\footnotetext{
3 Welsch (1990) argues that postmodernism has an implicit, new metanarrative-plurality. Its aim is to recognize and defend autonomous, heterogeneous ways of life. Morel (1995:275) sees this as well and reproaches Lyotard for creating just another totalizing norm.
} 
Stimulated by Habermas's intervention in 1980 , which became "a focal point of the debate" (Huyssen 1986:30), there was, and still is, a detailed discussion going on about the German idealism and the Enlightenment metanarrative. ${ }^{4}$ The Marxist narrative is hardly needed or employed any more since the decline of the USSR and Eastern European socialist countries in 1989. In the Western hemisphere this breakdown was interpreted and rejoiced at as a complete victory of capitalism. Some voices could even be heard claiming the end of history. What the capitalist societies in the United States, Canada, and Western Europe encounter nowadays is partly a consequence of these major changes, which left the Left without a sense of direction and unfit for political battles: The established social security and welfare systems are under serious conservative attack. The capitalist systems indeed seem to have withdrawn from the promise of wealth for everybody, and stress two other capitalist objectives-personal freedom of choice, and recognition and reward on the basis of merit. ${ }^{5}$

These current developments make Lyotard's thesis on the decline of the capitalist narrative the most intriguing metanarrative to me. Lyotard never elaborates on the capitalist metanarrative and he gives just a few reasons for its decline: "the 'crises of 1911 and 1929 ' refute the doctrine of economic liberalism, and the 'crisis of 1974-79' refutes the post-Keynesian modification of that doctrine" (Lyotard 1993c:29). This leads to many unanswered questions. Why did the idea of general abundance emerge at

\footnotetext{
4 In September 1980, when he was awarded the Theodor W. Adorno prize in the city of Frankfurt, Habermas gave a lecture, Modernity - An Incomplete Project, that led to a harsh but fruitful controversy with French poststructuralists. For an overview of this dispute see Lyotard (1993c), Jay (1991), Rorty (1991), and Huyssen (1986).

5 Preston (1967:42-46) analyzes the three most important and widely held objectives of capitalism.
} 
all? How did it change over time? How did it influence policies and the economy, and vice versa? Is it justified to talk about a decline of the capitalist metanarrative at all?

In this thesis I want to examine Lyotard's thesis and the emerging questions. This inquiry will take place within the context of the sociology of knowledge, a branch of sociology that studies the relations between thought and society. It attempts to relate the ideas it studies to the socio-historical settings in which they are produced and received.

The two most different perspectives on this relationship between ideas and a social base were given by Hegel and Marx. Hegel's idealist, dialectic philosophy of history gave the evolution of ideas a primary independent role in historical change, whereas Marx, in reaction to Hegel, emphasized the materialistic conditions of life:

In direct contrast to German philosophy which descends from heaven to earth, here we ascend from earth to heaven. That is to say, we do not set out from what men say, imagine, conceive, nor from men as narrated, thought of, imagined, conceived, in order to arrive at men in the flesh. We set out from real, active men, and on the basis of their real life-process we demonstrate the development of the ideological reflexes and echoes of this life-process. ... Morality, religion, metaphysics, all the rest of ideology and their corresponding forms of consciousness, thus no longer retain the semblance of independence. ... Life is not determined by consciousness, but consciousness by life. (Marx and Engels 1961[1846])

The tension between these two views cannot be resolved; only a close look at concrete historical examples reveals possible answers to the question how ideas are related to social structures. With this thesis I want to take such a close look by 
examining how the emergence and the development of the idea of general abundance is related to the socio-historical setting in which it was created, developed, and perceived. Or following Luhmann (1992) and stating it in more sociological terms, how is the "semantics" of the idea of general abundance related to its "structure." I will do this by examining the descriptions of the idea of general abundance in economic theory. For the structural side I will look at two fields-policies and the economy. My focus here will be, first, on how the economic structure influences the development of the idea, and second, on how the idea impacts on policies. Given that the vast majority of orthodox economists examined in regard to the idea-side of this thesis are British, the examination of the structural side will also look at British settings.

There can be no doubt that economic events have an influence on economic thought. Stigler (1965:17) aptly remarks: "To be sane, one must recognize at least a portion of the physical and social world in which he lives; so the sane economic theories have always had at least a possible connection with the world in which they were written." The question is to what extent such an influence exists. I will try to answer this by looking at the general development of the British economy, and the economic situation of the people.

Economists themselves seem to be very confident about their influence on policies. Robbins (1963:5) says: "There can be no doubt that throughout history economists of all schools have conceived their work as having the most intimate bearing on politics, both in the sense of the theory of political action and of the actual practice of 
affairs." An often quoted statement that supports this view is given by the economist John Maynard Keynes (1959[1933]:383):

The ideas of economists and political philosophers, both when they are right and when they are wrong, are more powerful than is commonly understood. Indeed the world is ruled by little else. Practical men, who believe themselves to be quite exempt from any influences, are usually the slaves of some defunct economist. Madmen in authority, who hear voices in the air, are distilling their frenzy from some academic scribbler of a few years back. I am sure that the power of vested interests is vastly exaggerated, compared with the gradual encroachment of ideas.

I will examine the relationship of the idea of general abundance and the economic and social policies by investigating if, and if so, how the British government intervened in the economy. Were economic and social policies influenced by policy recommendations of economists? Or did policy-makers not listen to the academic writers?

According to Preston (1967:56-74), there are five forms of state intervention: First, the government is called by competitors in economic struggles to give them an advantage or to counter an advantage by their opponents. Intervention of this kind include, for example, tariffs, bounties, patent laws, land grants, subsidies, and postal rates. Of special interest for this thesis will be labor legislation, which potentially can raise the bargaining power of labor and so "permit workers to share more widely in the growing prosperity of the nation through higher wages" (Preston 1967:59). The second type of intervention is aimed at giving capitalism a necessary legal framework. "... 
an economic system cannot function without a structure of law to support it. The law establishes the rights of ownership, the enforceability of contracts, and the standing of parties to deal with one another" (Preston 1967:59). This form of state intervention is of minor importance in regard to the theme of this thesis. The third type consists of intervention "to correct and supplement the effects of the market in meting out rewards and allocating power" (Preston 1967), and will be of major concern in this thesis. Besides assistance for agricultural and mixed government-private enterprises (e.g. in the fields of nuclear power and aerospace) this type of intervention includes the whole public sector that provides postal service, roads, national parks, etc., and, more important, public education, social welfare, and social insurances in cases of unemployment, retirement, accidents, and sickness. State intervention of the fourth type intend to counter the ups and especially the downs of business cyles by managing the supply and the demand of the economy with fiscal and monetary policies. This kind of state intervention became important from the 1930s onwards and will be a focus of this thesis as well. Finally, the state can intervene in the economy so as to supplant and control the market with a wide variety of regulations such as zoning laws, licensing procedures, and measures that protect the environment. Of importance for this paper will be the regulation of working conditions, for example, via the implementation of a minimum wage and maximum hour laws. 
As I will show, there are four distinct, successive periods that mark major shifts regarding the idea of wealth for everybody in orthodox economics. ${ }^{6}$ The idea emerged in Britain during the 18th century within the discipline of classical political economy. In the 1870s a new economic paradigm emerged that led to the neo-classical school, which dominated economics until the 1930s. At this time Keynesianism became the new orthodox view and kept this status until the mid-1960s, when two further schools_-monetarism and new classical macroeconomics—emerged and became dominant. However, this hegemony lasted for a few years only. In the early 1980 s Keynesian economics was revitalized within yet another school of economic thought, called new Keynesianism. This latest development in orthodox economics led to a situation were two competing paradigms have been existing-new classical and new Keynesian-, neither of them able to gain dominant status.

The development of the idea of general abundance in these four periods of economic thought will give the framework for the examination of the economic development and the policy-analysis. For the first three phases-classical political economy, neo-classical economics, and Keynesianism-I will describe in depth how these schools viewed the possiblity of general prosperity, and which policies they recommended in order to achieve this state. These descriptions will be focused on Adam Smith, David Ricardo, Alfred Marshall, and John Maynard Keynes, the outstanding and most influential representatives of their school of economic thought.

\footnotetext{
${ }^{6}$ I consciously exclude economic schools that contradicted orthodox economics, such as Marxism and the Austrian Historicist school from this analysis. As these were not the mainstream schools, their influence on policies is negligible, at least in Britain.
} 
The analysis of the fourth period will be somewhat different than the examination of the first three periods. For one, the last period is characterized by a multitude of competing economic paradigms which merely resurrect ideas of former developments in economics, without adding crucial notions in regard to the idea of wealth for everybody. Monetarism and new classical macroeconomics heavily draw upon the classical and neo-classical school while new Keynesianism revitalizes old Keynesian economic thought. Furthermore, with exception of Milton Friedman who was the most influential economist of the monetarist school, this last phase is not dominated by one or two economists. For these reasons I will keep the descriptions of the idea-side in this last period shorter, and focus more on the economic development and the policies.

I will argue that Lyotard is right by claiming a decline of the idea of general abundance. While wealth for everybody was explicitly promised by Adam Smith, the first classical economist that stated this idea, nowadays such statements cannot be found in economic theory. The examination of the economic and political structure suggests that the decline of the idea is closely related to these structural developments. We will see that throughout the last 200 years economists were influenced by sociohistorical settings, especially the economic structure. However, as O'Brien (1975:22) states, "there is often very little that the historian of theory (...) can point to as specific examples of the operation of such influences." Nonetheless, for two theorists, David Ricardo and John Maynard Keynes, this will be possible. In regard to the relationship between the idea of general abundance and the political structure, I will show that it is 

not possible to make generalizations about how the economic theories impact on policies. There are cases showing that policy descriptions of economists on the basis of the idea of general abundance seriously influence policy-makers, and there are cases that demonstrate exactly the contrary, that government did not adhere to these recommendations. 
II. The Making, the Development, and the Realization of the Idea of General Abundance

\section{The De-Moralization of Acquisitiveness}

To send the promise of, and belief in, wealth for everybody, and capitalism on its way, society's view of acquisitive behavior had to change drastically (Heilbroner 1985, Preston 1967, Deane 1965). In precapitalist societies wealth was a use value and an end in itself. It appeared as luxury consumption in forms of goods and services, as maintenance and deployment of armed forces, and as religious edifices. Idealized by the noblesse, and strongly engaged by the Catholic church, any excessive profitmaking and usury was widely disapproved of in traditional European societies. People did not strive for gain and profit (but for honor and glory), working and trading for reward was condemned, acquisitiveness was regarded as inappropriate.

This attitude is still reflected in Adam Smith's writings in the 18th century, when the British society had already encountered the beginnings of the Industrial Revolution. Smith regarded acquisitiveness as "contemptible and trifling" (Smith 1976[1759]:183), "most vulgar" (Smith 1976[1776]:342), and saw acquisitive societies in moral decline. 
While perceiving some advantages in the rise of commerce and industry, such as probity and punctuality, he emphasized damaging effects of the drive to amass wealth7:

These are the dissadvantages [sic] of a commercial spirit. The minds of men are contracted, and rendered incapable of elevation. Education is despised, or at least neglected, and the heroic spirit is almost utterly extinguished. To remedy these defects would be an object worthy of serious attention. (Smith 1976[1766]:541)

As Heilbroner (1985:33-38, 53-60; 1972[1953]:16-39) and Preston (1967:1720) show, in order to be able to transform from a pre- to a capitalist society, a generalization of wealth as capital was necessary. The morals in regard to acquisitive behavior had to vanish as "the single most important element in capitalism ... is the driving need to extract wealth from the productive activities of society in the form of capital" (Heilbroner 1985:33). In capitalism, wealth or capital is a means for gathering more wealth, not an end in itself as in pre-capitalist societies. ${ }^{8}$ This means that the low estimation of acquisitiveness in pre-capitalist societies had to turn into a "spirit of capitalism," to use Weber's famous term. "Wealth instead of being used for hospitality, ostentation, and worship, would need to be loaned or offered at its price-interest—or employed for profit, and the religious strictures against usury (...) would need to disappear" (Preston 1967:20).

\footnotetext{
7 Nevertheless, Smith promoted acquisitive behavior because he regarded it as useful for the economic development and material progress of society, which he valued more than morals. (See below in the chapter on classical political economy (2.2) and Adam Smith (2.3).)

8 On a more psychological level, Heilbroner (1985:44-53) describes two reasons for the drive to amass wealth in capitalist societies. First, being wealthy is a prestige, "with its freight of unconscious sexual and emotional needs." Second, wealth is an expression of power in the sense of having control over the access to goods.
} 
How was such an attitude change possible? How did money-making pursuits become honorable "after having stood condemned or despised as greed, love of lucre, and avarice for centuries past" (Hirschman 1977:9)? Hirschman (1977) argues that there was a movement in the broad area of social thought that appraised the consequences of acquisitive behavior and so created an "acceptable belief system" (Heilbroner 1985:110) around capital-extracting activities. This movement reinterpreted the love of lucre, regarded in precapitalist societies as a disruptive passion, as a harmonious interest.

... the case for giving free rein and encouragement to private acquisitive pursuits was both the outcome of a long train of Western thought and an important ingredient of the intellectual climate of the seventeenth and eighteenth centuries. (Hirschman 1977:69)

Based on Machiavellian ideas, a wide range of thinkers gave birth to the new view of acquisitive behavior-Montesquieu, James Steuart, John Millar, Blaise Pascal, Giambattista Vico, Georg W. F. Hegel, Bernard Mandeville, David Hume, Francis Bacon, François Quesnay, Adam Smith, etc. These men were concerned about how a stable order can be reached, when changes arising out of sustained economic growth in agriculture, trade, and manufacturing started to threaten the traditional, static societal structure. ${ }^{9}$ They solved this question by utilizing men's passions in a constructive way. The passion to amass wealth was interpreted as having a calming influence and civiliz-

\footnotetext{
9 Besides these economic changes the Reformation, the beginning of democratization, and scientific progress had a severe impact on the social thought at this time.
} 
ing effects on society and its members by working toward the general welfare of society and a viable social order. Men pursuing their self-interest, i.e. acquisitive behavior, were believed to serve themselves and society as well. Avarice became the civil passion that opposed other harmful passions such as ambition, lust for power, love of pleasure, and sexual lust. Thus, acquisitiveness was reinterpreted as a virtue and a legitimate interest for people.

In the numerous treatises on the passions that appeared in the seventeenth century, no change whatever can be found in the assessment of avarice as the 'foulest of them all' or in its position as the Deadly Sin that it had come to occupy toward the end of the Middle Ages. But once money-making wore the label of 'interests' and reentered in this disguise the competition with the other passions, it was suddenly acclaimed and even given the task of holding back those passions that had long been thought to be much less reprehensible. (Hirschman 1977:41-42)

The emerging discipline of political economy-various of its proponents helped reshape the attitudes toward the acquisitive drive-symbolized the reinterpretation of a harmful passion into a useful interest.

The very possibility of such a science itself implies that acquisitive behavior has lost its connection with the unruly passions and has come to be regarded as a steady principle of human 'motion,' capable of measurement and restraint. (Heilbroner 1985:111)

As I will show, the early classical economists justified unlimited acquisitiveness by arguing that according to natural laws production in an unregulated market econ- 
omy would steadily increase and benefits would spread wider and wider, bringing general abundance to individuals and the nation. 
2. Classical Political Economy (1776-1870s)

\subsection{The First Industrial Revolution}

Capitalism was not invented, but evolved in the process by which mankind emerged from its historic dependence upon an agriculturally-based economy. It is not somebody's theory put into practice, but practice that many have tried to explain in theory. (Preston 1967:37)

In the 18th century the first Industrial Revolution spontaneously, and without governmental support, started in Great Britain and gave way to a quick and disruptive transition from mercantilist to capitalist states in Europe and North America. As Deane (1965:2-3) shows, the actual starting-point of the Industrial Revolution is controversial among historians. Some trace it back to the mid-sixteenth century, others see its takeoff in the 1760s, but most scholars agree to date it in the 1780 s, "when the statistics of British international trade show a significant upward movement" (Deane 1965:3).

In the middle of the eighteenth century Britain was still a pre-industrial country. It had all the characteristics that stand for a pre-industrial and pre-capitalist economy and society (Deane 1965:5-17): the country and the vast majority of its people were poor, though there was some economic surplus; the standard of living and the level of productivity were essentially stagnant, as well as the social structure; agriculture was the main economic activity, but commerce and the textile industry were becoming important sectors; the labor force was still quite unspecialized. Despite these pre- 
capitalist characteristics the process of industrialization had already begun: "... the trend in population, prices, output and incomes was already turning upwards by $1750 "$ (Deane 1965:19).

Deane (1965) and Deane and Cole (1967) describe in detail the beginnings of British industrialization. The following summary of the most important threads is based on these two books.

The volume of trade rose enormously; British imports which were valued at $£ 39.6$ million in 1796 had risen to $£ 103$ million by 1853 , with domestic exports increasing from $£ 30.1$ million to $£ 71.4$ million. This involved a great broadening of the range of commodities traded as the British economy expanded and diversified.

Closely bound up with the developments in trade was a fundamental change in the balance of the British economy. Agriculture, which accounted for 40 to 45 per cent of national income in the years $1700-76$, had declined to only 26 per cent by 1821 and to 14 per cent by 1871 . Between 1801 and 1871 its share of the labor force fell from 36 per cent ( 1.7 million) to 15 per cent ( 1.8 million). During the same period, thanks to technological innovations, the agricultural output rose from $£ 75.5$ million to $£ 130.4$ million.

The rise of the manufacturing sector to predominance was impressive. Accounting for 24 per cent ( $£ 30.3$ million) of gross national product (GNP) in 1770 it accounted for 38 per cent ( $£ 348.9$ million) by 1871 . The great staple industries (textile, mining, iron, transport) grew up in this period. The output of the cotton 


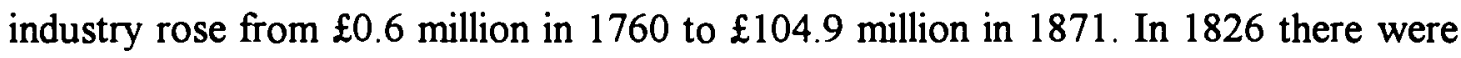
only 70 miles of railway open, by 1864 there were nearly 11,000 miles in use.

The population expansion began in the 1740s and reached a growth rate of 3.5 per cent per decade by $1751-61 .{ }^{10}$ By $1810-20$ the staggering figure was 16.9 per cent. The population of England and Wales which had been less than 6 million in 1700 had reached 22.7 million by 1871 . As a sign of the economic changes that were going on, more and more parts of the population lived in urban areas. While in 1760 only 21 per cent of the population were urban, this number rapidly increased to 33.9 per cent in 1800 , and to 48.3 per cent in 1840 (Crafts $1994: 44$ )

At the beginning of the eighteenth century national income was probably less than $£ 50$ million. By 1871 it had risen nearly forty times to $£ 916.6$ million. Despite the population increase, the GNP per capita increased at greater than 1 per cent per annum in the years 1801 to 1871 . Yet it is doubtful that there was any significant rise in real wages up to about 1820

... for the most part the rise in money wages lagged behind the increase in prices, poverty became an acute problem, food riots were common and it is very difficult to justify the view that standards of living of the mass of population were rising over the period 1780-1815. Moreover, in so far as industrialization led to urbanization it may have tended to worsen the environment of many people and to push up the death rate .... (Deane 1965:31)

10 These figures are "estimates based largely on records of baptisms, burials and marriages" (Deane 1965:23). The first census took place in 1801. See also the discussion of the population issue in 2.4 . 
Despite the fact that real wages increased from the 1820 s onwards, the 1830 s and 1840 s were "periods of widespread social and economic distress" (Deane 1965:142). Lindert (1994:373) reports that about 10 per cent of the work force at that time was unemployed. However, "it can hardly be doubted that by the middle of the nineteenth century the majority of the population were beginning to experience, though not yet to expect, a slow rise in their ordinary standard of living" (Deane 1965:223). This was partly due to social policies (see 2.5 ), and partly because of Britain's outstanding economic success in the 19th century.

Deane (1965:142-143) reports estimates of the purchasing power of buildingcraftsmen wages. In the 1780 s they were 15 per cent above the figure 100 years earlier, by the 1820 s it was again 12 per cent above the level of the 1780 s, and again it went up nearly 20 per cent by the 1830 s. Also, Deane (1965:143) gives some figures regarding the state expenditures on poor relief-while in $1688 £ 622,000$ (1.5 per cent of the national income) were spent for poor families, by 18002 per cent of the national income were spent to "support a much more liberal relief policy," called the Speenhamland system (see 2.5), which was introduced in 1796 nationwide and amended in 1834 . However, this relief system did not have widespread effects. According to Southall (1991) only about 5 per cent of the population received relief, and most of this money went not to able-bodied, unemployed adults, but to poor children.

There can be no doubt that poverty was still the predominant economic status of the vast majority of people, despite some improvements in the standard of living 
from 1820 onwards. In 1867 the top five per cent of British households shared about 41 per cent of the national income-a figure that shows that the British "were outstandingly unequal in income and wealth at that time" (Lindert 1994:379). Lindert (1994:379-380) reports that the wealth and income gap between rich and poor widened from the 1780 s onwards until the middle of the 19 th century when it came to its peak in the $1860 \mathrm{~s}$.

\subsection{The Emergence of the Classical School}

The changes in the economic structure were accompanied by the gradual development of economic theory into a modern science, called Political Economy by its founders. ${ }^{11}$

It was not until the eighteenth-century philosophers-primarily the physiocrats and Adam Smith-began systematically, and not merely incidentally, to apply to economic phenomena their theories of the natural order underlying the real world that economic theory began to develop into a unified system of explanation, a definitive technique of analysis. (Deane 1978:4-5)

Classical economists tried to explain and analyze the unprecedented economic growth and its consequences, such as the rise of the nation state and the development of a bourgeois society. There can be no doubt that these structural developments

\footnotetext{
11 There are four distinct epochs of western economic thought: classical Greek, Mediaeval scholastic, mercantilist, and modern (Deane 1978:1-5).
} 
exercised a strong influence on the thinking of the classical economists. As shown above, the idea of general abundance served as justification for a reinterpretation of acquisitive behavior as harmonious interest. The classical school was the first to state this idea within the emerging economic science.

The first stage of the new science of political economy was dominated by several British economists. They constituted the school of classical economic thought which became the basis for the development of economics for a century. It is usual to date the classical period from 1776-the year of the publication of Adam Smith's Wealth of Nations - to the 1870 s, when the marginal revolution led to the second era in economic thinking: neo-classical economics. ${ }^{12}$

The classical economists shared a system of theories, concepts and analytical techniques and so formed a paradigm in Thomas Kuhn's (1996[1962]) sense, and constituted an influential scientific community. One specific characteristic of the classical writers is that they were not merely academics, but men with diverse educational and professional backgrounds. ${ }^{13}$

... economics was not the exclusive preserve of a group of academic theorists and empirical research workers (amateur or professional) but the active concern of a heterogeneous collection of journalists, bankers, civil servants, politicians and others ... whose attempts at the objective explanation and/or prediction of economic behavior gave them as much claim to form part of the intellectual community of economists as the academics. (Deane 1978:94)

12 About differing views on how to date the classical period see O'Brien (1975:1-2).

13 O'Brien (1975:8-11) gives a brief overview of the education and professions of some of the classical economists. 
These men were strongly affected by the developments in the natural sciences.

"The advances of mathematics and celestial mechanics held out the hope that laws of motion might be discovered for men's action, just as for falling bodies and planets" (Hirschman 1977:13). Following natural-law philosophers such as Hugo Grotius, Samuel Pufendorf, and Francis Hutcheson (who was Adam Smith's teacher), the early political economists aimed at describing the economy "in terms of the operation of natural laws of human behavior" (Preston 1967:37). As O'Brien (1975:22) points out, a natural-law system involves the following four main propositions:

... that there is an underlying order in material phenomena; that this underlying order is discoverable either by reasoning from observed phenomena or from innate moral sense; that discovery of the underlying order leads to the formulation of natural laws which, if followed, lead to the best possible situation; and that positive legislation should reflect these natural laws.

Some theorists-Adam Smith did, David Ricardo did only partially—added the following further propositions:

... that natural laws are productive of immutable forces which man cannot defect or impede - this will be called determinism; that if freedom is accorded then society will progress harmoniously to a better state - this will be called harmony theory; and that therefore the operation of natural laws requires a great degree of freedom to achieve their ends-this will be called the natural liberty doctrine. 
In the classical economists' version the natural laws were viewed as desirable moral laws which, if followed by society, would promote material progress. "The natural order was the best possible one; once it was understood, all would see that the divergence of existing political and social institutions from it was the major obstacle to their welfare and would sweep them aside" (Burtt 1972:5).

As the term "Political Economy" symbolizes, a distinction between economic theory and policy descriptions was not made at that time; "scientific" conclusions and value judgments in accordance with the natural laws were used to support or disapprove governmental policies. ${ }^{14}$ The early economists' works were characterized by a strong ideological bias toward economic policies advocating economic individualism and laissez-faire. Only the free market, it was argued, would lead to a broad distribution of wealth. Laissez-faire policies were seen as reforms of existing mercantilist social and political institutions in the interests of greater individual freedom. Collectivism and state intervention were regarded as harmful for the enrichment of the nation and its people.

\footnotetext{
14 This attitude is illustrated by several economists of the classical period who personally did not separate science and politics: Adam Smith was Commissioner of Customs and Prime Minister in Scotland, David Ricardo and John Stuart Mill were Members of the British Parliament.

Starting with the marginal revolution in economics in the 1870 s, value-judgments as part of scientific analysis became discredited. At the beginning of the 20th century Max Weber and Vilfredo Pareto declared value-judgments as unscientific, and expected social scientists to separate science and politics. The subsequent struggle for a value-free science of political economy is discussed by Burtt (1972:4-7), Blaug (1968:676-678), Maloney (1985: 186-202), and Pribram (1983:228-230). In general it seems that-despite an acceptance among economists to make only neutral generalisations - "the focus of economics on politics ... has remained very intimate" (Robbins 1978[1952]:6-7).
} 
However, the classical economists did not see the natural order as flawless, and, hence, never intended a government that could not interfere at all with the economic domain. They assigned the political institutions important tasks: the defense of the country, taxation, and judicial administration. In this respect, they somewhat deviated from the natural-law principles. Viner (1958:249) says: "The classical economists did espouse laissez-faire, but a laissez-faire avowedly subject to qualification and requiring specific justification in each case of potential applications." While the classical writers were the earliest to fully appreciate the allocative mechanism of the market and the power and efficiency of this mechanism, they were perfectly clear that it could only operate within a framework of restrictions. Besides the mentioned governmental tasks, they recognized religious, moral, and conventional restrictions which were designed to ensure the coincidence of self and community interest. The exact framework required was to be revealed by experience, as defects in the operation of the system were discovered.

The classical period was dominated by Adam Smith (1723-90) and David Ricardo (1772-1823). "These two writers were without doubt the two major figures of Classical economics in terms of the influence they exercised ... both with respect to ... theories and to the conclusions of policy drawn from them ..." (O'Brien 1975:4). The following analysis shall, therefore, be focused on these two theorists. ${ }^{15}$

15 Of less, but still great importance for the classical period are the following British economists: Thomas Robert Malthus (1766-1834), James Mill (1773-1836) and his son John Stuart Mill (1806-73), John Ramsay McCulloch (1789-1864), Nassau Senior (1790-1864), Robert Torrens (1780-1864), Thomas Tooke (1774-1858), J. E. Cairnes (1823-75), and Henry Fawcett (1833-84). There was only 
2.3 Adam Smith (1723-90)

Adam Smith, an academic by profession, is regarded as the founder of modern economics. ${ }^{16}$ His Wealth of Nations (1976[1776]), which originated in a set of lectures held between 1767 to 1776 , became of very important for the discipline:

$\ldots$ he is the author to whom all orthodox nineteenth-century classical economists (on the continent of Europe as well as in Britain) consciously traced back the science they professed. The Wealth of Nations was an immediate best-seller. By 1800 the book had gone through nine English editions and had been published in the USA, Ireland and Switzerland. By the end of the first decade of the nineteenth century it had been published in the Danish, Dutch, French, German, Italian, Spanish and Russian languages. It was the undisputed, internationally accepted, bible of the new science of political economy .... (Deane 1978:6)

Why did Smith's economic theory, "the first fully systematic quasi-natural-law treatment of economics" (O'Brien 1975:29), have such a powerful and tenacious impact? According to Deane (1987:13-17), three accounts can be made for its success. First, Smith formulated the new discipline in philosophical rather than logical or mathematical terms and so gave it an intellectual status and appeal. Second, Smith's major concern was

one French among the classical economists-Jean-Baptiste Say (1767-1832). For further, more specialized, classical economists see O'Brien (1975:5-7).

16 Besides Adam Smith the French physiocrats, especially François Quesnay, are regarded as founders of modern economics. In contrast to Smith they exercised only a minor influence on the discipline. 
to explain economic development and 'the nature and causes of the wealth of nations'. His analytical method was to describe the 'natural' economic order by abstracting from the conflicts and imperfections which hindered its beneficent operations in the real world and by deducing logically its propensity to maximise economic welfare. (Deane 1978:14)

With his emphasis on growth and the distribution of wealth he addressed the primary economic problems at a time when the industrialization just started to take off. The most important issue then was how order would be possible during, and after, the transformation from a traditional, pre-industrial society into a modern, capitalist society. Of course, none of the contemporaries in the late 18 th century was able to actually foresee the scope of this transformation that would drastically change everybody's life, and the whole society. However, they surely anticipated some of the disruptions that were to come. ${ }^{17}$

In accordance with his contemporaries that reinterpreted acquisitive behavior as virtuous (see 2.1), Smith argued that individuals who are pursuing their self-interest would not undermine, but promote, society's interests and the common good as well. ${ }^{18}$

17 Smith himself wrote the Wealth of Nations in a pre-industrial context. It was first published in 1776 and revised in 1784. At this time the inventions that revolutionized the British textile industry and started the Industrial Revolution had already been made: the spinning jenny (1764), the spinning frame (1769), and the spinning mule (1779). Also, in 1784 the steam engine was considerably improved by John Watt. Smith did not anticipate the relevance of these technical improvements and the tremendous changes in the economy, and subsequently, the whole social and political structure that occurred only a couple of years after the publishing of the Wealth of Nations. "It is only in the late 1780 's that almost every statistical series of production in Britain begins to show a sharp trend" (Blaug 1968:40).

18 Dumont (1986) argues that emphasizing a natural harmonious order was a necessity for the classical economists, for the new emerging science tried to separate the economy from the political order. Smith in the Wealth of Nations made the point that an independent economic domain will be beneficial to society and so lay the ground for the books success, says Dumont. 
Consequently, he stated the idea of general abundance for the first time in the history of political economy.

Finally, Smith's harmonious view of society implied policy prescriptions against governmental restrictions on trade and the movement of capital and labor, as these state interventions impeded economic progress, according to Smith. This laissez-faire policy bias appealed to the bourgeois mercantile and manufacturing classes "which produced his most enthusiastic supporters" (Deane 1978:11). ${ }^{19}$ The wealth of nations

expressed the spirit of the Enlightenment with its optimism, belief in progress, and appeal to the common man. ... With markets free of government controls, Smith argued that savings promoted capital investment, and capital investment led to an increased division of labor, greater productivity, and rising real incomes. (Burtt 1972: 41-42)

\subsection{Theory of Society}

Smith provided his discipline with its first generally accepted paradigm. However, he was not an economist in the current understanding of the term, but a philosopher who saw political economy as one area of his moral philosophy. The Wealth of Nations is based on his first major book, The Theory of Moral Sentiments (1976[1759]), where he laid out his theory of society.

\footnotetext{
19 In fact, Smith's work is directed against the merchants and manufacturers that he blamed for the mercantilist system which, in his view, hindered economic progress and general abundance.
} 
In his Theory of Moral Sentiments, Smith develops his system of ethics on the basis of a doctrine of a harmonious order in nature guided by God, and in an incidental manner applies his general doctrine with strict consistency to the economic order. In his later work, the Wealth of Nations, Smith devoted himself to a specialized inquiry into the nature of the economic order. (Viner 1958:215-216)

Adam Smith viewed society as a sublime machine which, left to itself, would tend to maximize social welfare. "Human society, when we contemplate it in a certain abstract and philosophical light appears like a great, an immense machine, whose regular and harmonious movements produce a thousand agreeable effects" (Smith 1976[1759]:316).

The architect of this machine-a benevolent deity variously called by him "invisible hand," "the great Director of the universe," "the Author of nature," "the great Judge of hearts," "Providence," "the final cause," "the divine Being," or simply "God" — designed society according to a divine plan, which operates so as to maximize everybody's happiness and prosperity. "The happiness of mankind, as well as of all other rational creatures, seems to have been the original purpose intended by the Author of nature, when he brought them into existence" (Smith 1976[1759]:166). An unequal distribution of wealth was part of society's design.

When Providence divided the earth among a few lordly masters, it neither forgot nor abandoned those who seemed to have been left out in the partition. These last too enjoy their share of all that it produces. In what constitutes the real happiness of human life, they are in no respect inferior to those who would seem so much above them. In ease of body and peace of mind, all the different ranks of life are nearly upon a level, 
and the beggar, who suns himself by the side of the highway, possesses that security which kings are fighting for. (Smith 1976[1759]:185)

Hence, poverty was more a state of mind than a real problem in Smith's view. He saw material equality not as an absolute goal or an end in itself, just as he regarded wealth not as a prerequisite to act virtuous. Besides this Smith believed in the natural order and its egalitarian effects:

The rich only select from the heap what is most precious and agreeable. ... they divide with the poor the produce of all their improvements. They are led by an invisible hand to make nearly the same distribution of the necessaries of life, which would have been made, had the earth been divided into equal portions among all its inhabitants, and thus without intending it, without knowing it, advance the interest of the society .... (Smith 1976[1759]:184-185)

What is behind this automatism? "Nature, when she formed man for society, endowed him with an original desire to please, and an original aversion to offend his brethren" (Smith 1979[1759]:116). Moral sentiments ensure that men by responding to their natural feelings, original passions, and personal ambitions, i.e., material self-interest, will fulfill the divine plan. "... by acting according to the dictates of our moral faculties, we necessarily pursue the most effectual means for promoting the happiness of mankind" (Smith 1759[1979]:166). These moral sentiments or faculties that direct the conduct of life and produce the most agreeable effects are beneficence (including sympathy, generosity, kindness, and friendship), justice, and prudence (including industry and frugality) (Smith 1976[1759]:262-264). Smith especially emphasized jus- 
tice as a superior virtue in arguing that beneficence is just an "ornament" of society, justice however, "the main pillar that upholds the whole edifice," so that if justice was removed, the "immense fabric of human society ... must in a moment crumble into atoms" (Smith 1776[1759]:86).

\subsubsection{The "Wealth of Nations"}

The theory of society is the background for Smith's economic writings. "In the Wealth of Nations the basic framework of this theory of society is taken for granted and Adam Smith goes on to work out a special case of its application-the economic case" (Deane 1978:9).

Smith saw men driven entirely by the desire of bettering their condition. Behind this desire is a longing for honor, respect, dignity, and recognition:

... it is chiefly from regard to the sentiments of mankind, that we pursue riches and avoid poverty. For to what purpose is all the toil and bustle of this world? what [sic] is the end of avarice and ambition, of the pursuit of wealth, of power, and preeminence? ... From whence, then, arises the emulation which runs through all the different ranks of men, and what are the advantages which we propose by that great purpose of human life which we will call bettering our condition? To be observed, to be attended to, to be taken notice of with sympathy, complacency, and approbation, are all the advantages which we can propose to derive from it. It is the vanity, not the ease, or the pleasure, which interests us. (Smith 1976[1759]:50) 
Individuals, equipped with their instinctive moral virtues of beneficence, justice, and prudence, are impelled to amass their own fortunes in ways that tend to maximize the total income of the community or the nation as well as their own, so thought Smith. In this way they unconsciously harness their acquisitive passion and self-interest.

Every individual is continually exerting himself to find out the most advantageous employment for whatever capital he can command. It is his own advantage, indeed, and not that of the society, which he has in view. But the study of his own advantage naturally, or rather necessarily leads him to prefer that employment which is most advantageous to the society ... (Smith 1976[1776]:454)

As every individual, therefore, endeavours as much as he can both to employ his capital in the support of domestick industry, and so to direct that industry that its produce may be of the greatest value; every individual necessarily labours to render the annual revenue of society as great as he can. He generally, indeed, neither intends to promote the publick interest, nor knows how much he is promoting it. ... he intends only his own security; and by directing that industry in such a manner as its produce may be of the greatest value, he intends only his own gain, and he is in this, as in many other cases, led by an invisible hand to promote an end which was no part of his intention ... By pursuing his own interest he frequently promotes that of the society more effectually than when he really intends to promote it. (Smith 1976[1776]:456)

Smith subjected the economic system to an empirical test of his theory of society; the Wealth of Nations is focused on the behavior-patterns of real people within the constraints of existing institutions. He applied "facts gathered by personal observation at home and abroad, by conversation and correspondence with many keen and intelligent observers of the current scene, by wide reading in a miscellany of sources ..." 
(Viner 1958:230). The economic realities led Smith to draw a picture of a less perfect and universal harmonious order than outlined in the Theory of Moral Sentiments. In the Wealth of Nations

this harmony is represented as not extending to all elements of the economic order, and often as partial and imperfect where it does extend. Where harmony does prevail, it is as a rule a sort of average or statistical harmony, revealing itself only in the general mass of phenomena and leaving scope for the possibility that natural processes whose general effect is beneficial may work disadvantageously in individual cases or at particular moments of time. As a rule, though not invariably, Smith qualifies his assertions of harmony by such phrases as 'in most cases', 'the majority', 'in general', 'frequently'. (Viner 1958:222)

Throughout the Wealth of Nations Smith gives instances for defects in the natural harmonious order. Masters and workmen have a conflict of interest with respect to wages, and the weakness in bargaining power of the latter ordinarily gives advantage in any dispute to the former (Smith 1976[1776]:83-85). Masters, traders, and apprentices, on the one hand, and the public on the other, have divergent interests with respect to apprenticeship rules (Smith 1976[1776]:139-140, 151). The interest of merchants and manufacturers is in high profits, which are disadvantageous to the public (Smith 1976[1776]:128, 628-630). Merchants and manufacturers have interests opposed to those of the farmers and landlords (Smith 1976[1776]:144-145).

People of the same trade seldom meet together, even for merriment and diversion, but the conversation ends in a conspiracy against the publick, or in some contrivance to raise prices. It is impossible indeed to prevent 
such meetings, by any law which either could be executed, or would be consistent with liberty and justice. (Smith 1976[1776]:145)

Furthermore, Smith argued, men commonly over-estimate their chances of success in risky ventures with the consequence that too great a share of the nation's capital goes into such ventures (Smith 1976[1776]:124-128).

One would think that in light of these defects Smith would advocate government intervention that would promote general welfare. However, based on his experience of incompetent and corrupt British government ${ }^{20}$, Smith rejected such regulations. Convinced that considerable economic progress is possible without the support of the government, he strongly advocated laissez-faire:

... every man is continually making [efforts] to better his own condition, [this] is a principle of preservation capable of preventing and correcting, in many respects, the bad effects of a political œconomy, in some degree, both partial and oppressive. Such a political œconomy, though it retards more or less, is not always capable of stopping altogether the natural progress of a nation towards wealth and prosperity, and still less of making it go backwards. ... the wisdom of nature has fortunately made ample provisions for remedying many of the bad effects of the folly and injustice of man .... (Smith 1976[1776]:674)

The natural effort of every individual to better his own condition, when suffered to exert itself with freedom and security, is so powerful a prin-

20 "The standards of honesty and competence of the governments of his day with which Smith was acquainted with were unbelievable low ... Smith had encountered few instances in which government was rendering intelligent and efficient service to the public welfare at the fields of protection and justice. The English government of his day was in the hands of an aristocratic clique, the placejobbing, corrupt, cynical, and class-biased flower of the British gentry, who clung to the traditional mercantilism not so much because of a strong faith that it met the problems of a growing trade struggling to burst its fetters, but because they did not know anything else to do." (Viner 1958:234235) 
ciple, that it is alone, and without any assistance, not only capable of carrying on the society to wealth and prosperity, but of surmounting a hundred impertinent obstructions with which the folly of human laws too often encumbers its operations .... (Smith 1976[1776]:540)

Moreover, analyzing the defects in the natural order, Smith attacked government restrictions and regulations that he regarded as the major cause of the defects, as they channeled investments in different canals than the natural order would, and undermined competition on a free market. Only free competition, he thought, would result in the most agreeable effect for society, as it would prevent landlords, manufacturers, merchants, and farmers from only serving their self-interest. "All systems either of preference or of restraint, therefore, being thus completely taken away, the obvious and simple system of natural liberty establishes itself of its own accord" (Smith 1976[1776]:687). This led Smith to call for an extensive program of reforms designed to bring the economic system closer to the system of natural order.

Adam Smith still had a clear view of the 'natural order' to which the economic system ought to approximate but was prepared to admit to certain flaws in its operation in the real world. The 'great architect' needed some cooperation from the economic policy makers to allow his machine to work in the most effective way. (Deane 1978:10)

He advocated four main reforms that would abolish existing restrictions and regulations that he believed hindered the attainment of a free competitive market.

Free choice of occupations is to be established through the abolition of the apprenticeship regulations and settlement laws; free trade in land, 
through the repeal laws establishing entails, primogenitures, and other restrictions on the free transfer of land by gift, devise, or sale; internal free trade, where such does not already prevail, by the abolition of local customs taxes; the most important of all, free trade in foreign commerce, through the abolition of the duties, bounties, and prohibitions of the mercantilist régime and the trading monopolies of the chartered companies. (Viner 1958:227).

Smith did not have much hope that the rise of commerce and industry would create a better government. "The violence and injustice of the rulers of mankind is an ancient evil, for which, I am afraid, the nature of human affairs can scarce admit of a remedy" (Smith 1976[1776]:493). Consequently, he restricted governmental activities to three distinct spheres:

According to the system of natural liberty, the sovereign has only three duties to attend to; three duties of great importance, indeed, but plain and intelligible to common understandings; first, the duty of protecting the society from the violence and invasion of other independent societies; secondly, the duty of protecting, as far as possible, every member of the society from the injustice or oppression of every other member of it, or the duty of establishing an exact administration of justice; and, thirdly, the duty of erecting and maintaining certain publick works and certain publick institutions, which it can never be for the interest of any individual, or small number of individuals, to erect and maintain (Smith 1976[1776]:687-688)

With the third function Smith assigned to the government some duties of promoting general welfare, if the individuals did not have the means to do so. Public works and institutions were "chiefly those for facilitating the commerce of society, and those for promoting the instruction of the people" (Smith 1976[1776]:723). As public 
works he mentioned highways, bridges, canals, and harbors (Viner 1958:724). Government institutions that he approved were the post-office, patents and copyrights, and public education (Smith 1976[1776]:724, 754, 758-788). The latter he viewed as a necessity for the whole society, as he believed that educated people were better workers, soldiers, and citizens.

\subsection{David Ricardo}

By the first decade of the 19th century, when the first courses on political economy were taught and the first professors of political economy were appointed in Britain, this new discipline was acknowledged as a science, however, its academic status was still pretty low. The academic changes were encompassed by the emergence of "a self-conscious intellectual community" in Western Europe, whose members' "common ground lay in the fact that, having read the Wealth of Nations, they were concerned both to apply its analysis to current economic problems and to develop, criticize and extend its basic theory wherever necessary" (Deane 1978:71). These men were convinced that political economy was able to analyze economic policy problems and based on this could provide policy prescriptions. ${ }^{21}$ David Ricardo, a very successful broker at the London stock exchange, "the first working-class theorist" (Milgate and Stimson

21 McCulloch, a Scottish journalist, became professor for political economy at the London University in 1827. His lectures attracted an audience of up to 800 people, among them bankers, merchants, and Members of the British Parliament. (Deane 1978:71-72) 
1991:9), self-educated to a considerable extent, was one of the members of this group.

A disciple of Smith, he replaced his teacher as the authority in economic theory. Smith's reliance on the natural harmonious order, created by a benevolent deity, resulted in a denial of him as founder of the discipline. This went so far that the 19th century neo-classical economists regarded Smith's economic theories as unscientific.

It is possible to quote his [Smith's] authority in support of many errors ... For instance he had not quite got rid of the confusion prevalent in his time between the laws of economic science and the ethical precept of conformity of nature. 'Natural' with him sometimes means that which the existing forces actually produce or tend to produce, sometimes that which his own human nature makes him wish that they should produce. (Marshall 1890[1961]:227)

In contrast, Ricardo "ignored any reference to metaphysical forces operating behind the scenes of the economic world" (Pribram 1983:143). He did not have a moral philosophical background for his economic thoughts and so took Smith's place. He became the first specialist economist and developed a new technique of economic analysis, free from philosophical axioms and historical generalizations (Fitzgibbons 1995:89).

Ricardo's characteristic approach to the urgent economic issues of his day was thus to begin by trying to formulate the laws underlying the relevant categories of economic behavior, to develop a theory based on a few precisely stated assumptions and to illustrate it by reference to the facts of the contemporary world. From this essentially abstract reasoning process he deduced practical policy conclusions. (Deane 1978:76-77) 
Hence, his methodology was mathematical rather than philosophical or historical, deductive rather than inductive. However, it cannot be denied that Ricardo was heavily influenced by the economic development and the policies during his time.

Two issues dominated political discussions and struggles in the early 19th century: the growth of the population and the Corn Laws. ${ }^{22}$ Adam Smith had argued that a growing population is a sign of wealth. However, during the last decades of the 18th century, based on "amateur statisticians" (Heilbroner 1972[1953]:73), the British believed that their population is in decline. ${ }^{23}$ In the first quarter of the 19th century several censuses were held that might have relieved the British anxieties as the returns showed that the British population was growing at an accelerating rate (Blaug 1968:69). There was not a lot of time for enthusiasm though, as Thomas Robert Malthus, an influential economist of the classical school, draw a quite pessimistic picture about the effects of such growth (see 2.4.1).

The Corn Laws were an indirect result of the growing population. Due to this growth the demand for grain exceeded the supply and England was forced to import foodstuffs. The price for corn rose dramatically at the beginning of the 19 th centuryHeilbroner (1972[1953]:78) reports a quadrupled price-and in turn the rents, i.e. profits of the landlords. Heilbroner (1972[1953]:78) gives an example of a mediumsized farm that enlarged its profits from $£ 88$ in 1790 , to $£ 121$ in 1803 , up to $£ 160$ in 1813. The increasing agricultural profits attracted merchants to buy cheap corn

22 For an overview of the Corn Law debate see Deane (1965:186-201).

23 Heilbroner (1972[1953]:73-76) discusses the historical situation of British fears about their declining population until the first census took place in 1801 . 
abroad, which they sold in England at the high price-level. The landlords that dominated the Parliament at that time knew how to stop this. They passed the Corn Laws which protected the British agriculture by imposing tariffs on imported grain (Deane 1978:60). The merchants and manufacturers opposed these laws as they were interested in low prices for corn, for the price of food largely determined the wages at that time, which barely covered the subsistence level. The Corn Laws initiated a bitter conflict between the landed gentry and the rising bourgeoisie, and raised questions about the distribution of wealth between rents, profits, and wages. The Corn Law dispute symbolically stands for the struggle for political and economic power (Deane 1978:78-80).

\subsubsection{The "Principles"}

In this historical context Ricardo started to systematically study the principles of political economy. In 1815 his Essay on the Influence of a Low Price of Corn on the Profits of Stock was published, followed in 1817 (re-edited in 1819 and 1821) by his major economic work, the Principles of Political Economy and Taxation. In the introduction to the Principles he clearly stated what his intention was-to develop a law that would show the distribution of the national income among three classes: capitalists that earned profit, landowners that earned rent, and workers that earned wages. 
To determine the laws which regulate this distribution, is the principal problem in Political Economy: much as the science has been improved by the writings of Turgot, Stuart, Smith, Say, Sismondi, and others, they afford very little satisfactory information respecting the natural course of rent, profit, and wages. (Ricardo 1951[1817]:5)

Ricardo's economic theory had three distinct elements in regard to the idea of general abundance-the theory of rent, the impact of a growing population on the rate of profit, and the subsistence theory of wages. Before I will introduce his theories, I will turn to a close friend of Ricardo-T. R. Malthus. He developed a law of population which is a key component of Ricardo's theory. ".. the Malthusian theory lent support to the subsistence theory of wages and prepared the way for the Riccardian preoccupation with the land-using bias of economic progress" (Blaug 1968:68).

Malthus introduced his ideas on population growth in a 1798 published treatise entitled An Essay on the Principle of Population as It Affects the Future Improvement of Society. As Heilbroner (1971[1953]:76) aptly remarks,

with it perished at one blow all the fond hopes of a harmonious universe. In a few pages young Malthus pulled the carpet from under the feet of the complacent thinkers of the times, and what he offered them in place of progress was a prospect meager, dreary, and chilling.

Why? "Malthus saw the fruits of economic development inevitably eaten up by an ever-expanding population" (Preston 1967:38). He believed that the population tended to increase at a geometrical ratio, whereas the food supply only grew at an arithmetic ratio: 
Taking the population of the world at any number, a thousand millions, for instance, the human species would increase in the ratio of $-1,2,4$, $8,16,32,64,128,256,512, \quad \& \mathrm{c}$. and subsistence as$1,2,3,4,5,6,7,8,9,10, \& c$. In two centuries and a quarter, the population would be to the means of subsistence as 512 to 10 : in three centuries as 4096 to 13, and in two thousand years the difference would be almost incalculable .... (Malthus 1960[1798]:13)

As people "are all impelled by a powerful instinct to the increase of their species, and this instinct is interrupted by no reasoning of doubts about providing for their offspring" (Malthus 1960[1798]:14), he saw the population growing beyond the means of subsistence. Therefore, he argued, the poor were condemned to a wretched subsistence, as they destroyed their own well-being by producing too many children. With this analysis Malthus disproved "that the unequal distribution of private property was responsible for the poverty of the large masses of population" (Pribram 1983:153). He saw only two checks that can stop population from growing so fast (Malthus 1960[1798]:158-165). Positive checks-i.e. "all unwholesome occupations, severe labor and exposure to the seasons, extreme poverty, bad nursing of children, great towns, excesses of all kinds, the whole train of common diseases and epidemics, wars, plague, and famine" (Malthus 1960[1798]:160)—that raise deaths and hold the population at levels the world can support. And preventive checks that lower the birth rates in the form of moral restraint and prudence-i.e. late marriage and fewer children. Only the latter checks, Malthus believed, could bring any long-term betterment to the condition of the poor. 
Ricardo integrated Malthus's principle on population and developed it further. In his theory of rent he explained rent differentials in agriculture as a result of Malthus's argument. Rent is defined by Ricardo as the "portion of the produce of the earth, which is paid to the landlord for the use of the original and indestructible powers of the soil", the surplus above the cost of production (Ricardo 1951[1817]:67). Ricardo saw rent as being determined by price: "Corn is not high because a rent is paid, but a rent is paid because corn is high" (Ricardo 1951[1817]:74). His model started with the assumption that land is specialized and in fixed supply, but that not all land is in use. Ricardo, drawing upon Malthus's population theory, argued that new, but less accessible and/or less fertile land is cultivated as the population grows and with it the demand for food; "... in the progress of population, land of an inferior quality, or less advantageous situated, is called into cultivation" (Ricardo 1951[1817]:70). He analyzed that the cost of production of corn varied with the fertility of the soil and its situation in relation to the market. What determined the market price of corn, so Ricardo, were the capital and labor inputs in the least productive piece of land. Therefore, argued Ricardo, the price of corn was always high enough to cover the cost of production on the least productive land in use. Differential rents were the result of this principle. On the marginal land he saw no rent at all—only the production costs were covered. On the best land, a high surplus was achieved that the owner of the land accumulated. "With every step in the progress of populations, which shall oblige a country to have 
recourse to land of a worse quality, to enable it to raise its supply of food, rent, on all the more fertile land, will rise" (Ricardo 1951[1817]:70).

Second, Ricardo connected the theory of rent with the rate of profit. Economic growth, he argued, leads first of all to a certain accumulation of profits on the side of the capitalists, which they will invest. This leads to an increase in the demand for workers and a rise in the rate of wages. Drawing upon Malthus, Ricardo argued that each rise in wages gives a "continued stimulus to an increase in people" (Ricardo 1951[1817]:95). As shown above, this growing population required the cultivation of more and more and poorer and poorer land at increasing costs, thus raising food prices and the wages needed to provide workers with the subsistence level (see below). "If, as is absolutely certain, wages should rise with the rise of corn, then profits would necessarily fall" (Ricardo 1951[1817]:111). Therefore, so Ricardo, the capitalists that invest their profits and so are the major force behind economic progress, are struggling in vain against a rising tide of wages and rents. He predicted that their profits would get squeezed out by the growing population. The only beneficaries in this scenario were the owners of good land: they were growing food at low costs, and sold it on a market whose price was being determined by the costs of producing food on the least productive land in use. "All classes, therefore, except the landlords, will be injured by the increase in the price of corn" (Ricardo 1951[1817]:336).

Ricardo's third element of his economic theory is the subsistence theory of wages, that in short stated that wages are determined by the supply of labor, however 
tended toward the subsistence level. He viewed this level as the natural price of labor "necessary to enable the labourers one with another, to subsist and to perpetuate their race" (Ricardo 1951[1817]:93). The natural price depended on "the quantity of food, necessaries and conveniences required for the support of the labourer and his family" (Ricardo 1951[1817]:93). In contrast, the market price of labor was "the price really paid for it" (Ricardo 1951[1817]:94). As shown above, Ricardo argued that an industrializing society encountered an increase in capital that stimulated a growth of the population, followed by higher food prices and even higher wages. He believed that, finally, capitalists would not invest their diminishing profits any more and hence the demand for labor would decline. The wages would fall back to the natural price, namely the subsistence level. This in turn stopped the steady growth of the population, however, only until the circle would start again.

According to Ricardo a "stationary state" was the result of economic growth and progress - "a gloomy state where the worker just barely subsisted, where the capitalist was cheated of his efforts, and where the landlord gloated over his unearned and constantly growing spoil" (Heilbroner 1972[1953]:100).

Ricardo gave economics and capitalism "a curiously inhumane touch" (Preston 1976:38). His economic theory was "devastating to the pleasant premises of the age of Adam Smith" (Heilbroner 1972[1953]:77). Growth did not lead to general abundance but was a process in the direction toward a "stationary state." 
... what Ricardo foresaw was the end of a theory of society in which everyone moved together up the escalator of progress sketched out by Smith. On the contrary, Ricardo saw that the escalator worked with different effects on different classes, that some rode triumphantly to the top, while others were carried up a few steps and then were kicked back down to the bottom. Worse yet, those who kept the escalator moving were not those who rose with its motion, and those who got the full benefit of the ride did nothing to earn their reward. And to carry to metaphor one step further, if you looked carefully at those who were ascending to the top, you could see that all was not well here either; there was a furious struggle going on for a secure place on the stairs. (Heilbroner 1972[1953]:77)

With Ricardo's theory the idea of general abundance is in decline as early as the beginning of the 19th century. Moreover, Ricardo and also Malthus provided the ruling class with a justification for their laissez-faire policies in regard to poverty:

The tendency of these theories was to suggest that the poverty and misery visible everywhere in the early stages of industrialization were neither preventable, nor the fault of those in command of the economic order. ... the fatalism of these early theories ... forestalled serious consideration in capitalist economic theory of alleviating the condition of the poor. What for society did for them was useless, if not actually harmful .... (Preston 1967:38)

To relieve poverty directly by state subsidies or private charity, Ricardo and Malthus argued, was to remove directly the principal check against an increase in population, i.e., the necessity for poor people to fend for themselves and to bear the full burden of their own improvidence.

It is a truth which admits no doubt, that the comforts and well-being of the poor cannot be permanently secured without some regard on their 
part, or some effort on the part of the legislature, to regulate the increase of their numbers, and to render less frequent among them early and improvident marriages. The operation of the system of poor laws has been directly contrary to this. They have rendered restraint superfluous, and have invited imprudence, by offering it a portion of the wages of prudence and industry. (Ricardo 1951[1817]:107)

Consequently both theorists urged the gradual abolition of the poor relief system, that was inaugurated by the Berkshire magistrates at Speenhamland in 1795 and ratified by the British Parliament in the following year (see 2.5). Furthermore, Malthus opposed housing projects for the working class, and Ricardo's theory about the tendency of wages to fall back to the natural price gave capitalists a justification for not paying workers wages beyond the subsistence level.

\subsection{The Revolution of Government}

English economics was throughout the nineteenth century intimately bound up with English politics, and throughout the century English economists had, probably without any important exceptions, political affiliations or preferences which influenced and were influenced by their economic doctrines. It is possible to ascertain with some degree of assurance the political affiliations of the earlier economists from their economic writings. (Viner 1958:247)

As shown, Smith and Ricardo advocated laissez-faire policies based on their economic analysis. The question is, if British governments followed their recommendations. 
There were three issues that kept British economists and politicians busy throughout the nineteenth century: foreign trade policy, the economic role of the state, and the relief for the poor (Viner 1958:247).

Deane (1965: 202-219) analyzes these issues during the classical period, asking how far it was true that the classical economists' doctrine of laissez-faire triumphed. First, one has to acknowledge "that between 1760 and 1850 a mass of governmental rules and restrictions on economic activity, many of them dating from medieval times, were swept out of the statute book" (Deane 1965:203). ${ }^{24}$ For instance, the classical period saw a revolution in policy toward trade. The most important reforms in this field were starting in 1842 , when a review of British tariffs began and culminated first, in the budget of 1845 , which saw duties on over 400 items removed, and second, in the repeal of the Corn Laws in 1846. Also, policy of labor relations followed the trend of liberalization after the Napoleonic Wars. In 1825 a Combination Act was passed that legalized worker's associations, i.e. unions, for purposes of collective negotiations of wages and working conditions (Deane 1965:210). These examples can be interpreted as policies following Smith's, Ricardo's, and other classical economists' advice. However, a closer look at the reasons for the repealing of the regulations and at the substitutions for them shows that such an interpretation is only partly right.

One main reason for the dismantling of restrictions of economic activity was that they "were more tiresome than effective" (Deane 1965:207). Policy-makers real-

24 The period of the Napoleonic Wars (1793-1815) turned this general trend upside down and "it is reasonable to suppose that the heavy burden of Protectionism in post-war Britain hindered the recovery of British industry and intensified the social distress involved in economic change" (Deane 1965:208). 
ized that they would meet their ends rather by imposing "mild regulation effectively enforced" than "over-repressive measures" that nobody followed, as the government did not have the financial and organizational capacity to enforce the regulations (Deane 1965: 211). In other words, if governments wanted to conduct economic affairs they had to realize their limitations, but also their opportunities. And that is exactly what British governments did from the late 18th century onwards.

$\ldots$ as industrialization proceeded the state was intervening more deeply and more effectively in the economy than it had ever done before. There was indeed a revolution in the technique and philosophy of government ... a revolution in organization and behavior and in the personnel taking the effective policy decisions ... a revolution in government which represented the beginnings of collectivism and of the modern welfare state .... (Deane 1965:214)

Even though much state regulation was swept away, the classical period encountered a revolutionary growth of effective state power, that reached the "point of no return" already in the 1830s (Deane 1965:215). This is reflected in the rise in state spending from $£ 14$ million in 1776 to nearly $£ 70$ million in 1870 , and the introduction of an income tax in 1798 .

As I have shown Smith did not consider any kind of poor relief. Smith, writing at a time when the industrialization just started and poverty was not an public issue yet, saw poor relief immanent in an economico-political order that followed the natural laws and hereby would enhance general abundance automatically. Ricardo argued, that the poor masses prevented themselves from gaining profit from industrial progress, as they 
were growing too fast. Poverty, therefore, he saw as a way to put a strain on men's sexual desire. Consequently, Ricardo overtly opposed any kind of poor relief.

British politics did not support the radical views of the two economists in this regard, however, their influence can still be traced back in the details of and attitudes toward social policies.

By the late 1830's there was opposition only from one wing of the Tories and from the extreme radicals to the principle of confining relief to the able-bodied poor on the basis of 'less eligibility'; that is, of granting it only in such unattractive form that the incentives to industry, thrift, and prudential control of the birth-rate should not be undermined. (Viner 1958:247-248)

No matter which authority we consult on the English Poor Laws in the nineteenth century, the same conclusions emerge: the Old Poor Law [1795-1834] demoralized the working class, promoted population growth, lowered wages, reduced rents, destroyed yeomanry, and compounded the burden on ratepayers; the more the Old Poor Law relieved poverty, the more it encouraged the poverty which it relieved. (Blaug 1963:151)

Blaug $(1963,1963)$ examined this widespread belief, nourished by MalthusianRicardian economics, and concluded that there were no empirical evidences for it.

As mentioned above, in 1795, for the first time in British history ${ }^{25}$, the magistrate at Speenhamland introduced a poor relief system for its needy workers, which was subsequently accepted by the Parliament for the whole island in 1796 . This old Poor

\footnotetext{
25 Dietz (1949:275-277) shows that already in the 16th and the 17th century some forms of relief for the poor on a local basis existed. In contrast to the Speenhamland system the concrete measures were not based on a law and so were rather dependent on the goodwill of the more wealthy inhabitants of the town or cities.
} 
Law, which "constituted a 'welfare state in miniature'" (Blaug 1964:229), was amended in 1834 (New Poor Law). The amendment was characterized by "a revolution in British social administration, but it left the structure of relief policy unchanged" (Blaug 1964:229). ${ }^{26}$

The reasons for the introduction of the Speenhamland system are quite obvious. In accordance with the classical theorists' laissez-faire doctrine, industrial wages at that time were determined by two factors only: the state of trade (demand) and the supply of labor. Consequently, trade depressions and harvest crises were encompassed by rising prices, a higher unemployment rate, and lower wages. So the law of $1795 / 96$ became a necessity:

Given that toth kinds of unforeseen disaster were frequent in the climatically unfavourable and wartorn years of the late eighteenth and early nineteenth centuries, it is difficult to see how the country could have avoided social and political upheaval without a fairly liberal poorrelief. (Deane 1965:143)

How did the Old Poor Law work? It authorized outdoor poor relief (in contrast to workhouses) by all parishes and consisted of three components: allowance payments for children, unemployment compensations, and compensations for workers who received substandard wages (Hollander 1979:541). The children allowances were "generally paid for a third, fourth, or fifth child, and this amount was related in each parish to the local employment opportunities for children" (Blaug 1964:232). Unem-

26 For a description and evaluation of the Speenhamland system see two articles of Blaug (1963, 1964). 
ployment compensation and the supplementation of wages were based on the price of bread and the number of dependents; it constituted a first kind of minimum standard of living.

There were further governmental interventions in the economy on humanitarian grounds (Crouzet 1982:105-112). In 1788 the Hanway Act protected the chimneysweeps from exploitation; in 1802 an act passed Parliament that controlled the working conditions of children; the Passenger Act of 1803 protected poor emigrants. Later in the 1830s legislation started to include effective inspections and enforcements of the laws that improved the conditions of work. According to Dietz (1949:429) the first factory act in 1833 included the setup of four inspectors which had to enforce the provisions of the new law. The same act excluded children under nine from work in factories and it set maximum work hours for the older children. In 1847 the ten-hour-day was introduced, in the 1840 s attempts were made to organize an effective national health service. In 1842 an act forbade women and small children to work underground in coalmines, and in 1844 women work in factories was limited to twelve hours a day. Furthermore, local governments, especially in urban regions started legislative protection of the poor. For example, it was "at the local level that government first began to regulate the activities of landlords and speculative builders, who were turning the centres of the great industrial cities into insanitary slums" (Deane 1965:219). 
In one of the few instances for which Smith and Ricardo recommended governmental action in order to improve the situation of the poor, the education of the people, the British government did not follow the theorists view and stayed inactive.

Jealousies among those who wanted to manage the education of the people together with traditions that mass education was not really necessary and might even prove undesirable, if it led people to read radical literature, prevented the inauguration of any state system of popular education until 1870. (Dietz 1949: 430)

The reasons for the gradual shift in social policy from laissez-faire to the beginning of collective welfare at the end of the 18th century are aptly described by Viner (1958:249):

The growing information about working and living conditions in the factory towns, the steadily increasing political power of the working classes even under the restricted suffrage of the Reform Act of 1832, and the widespread humanitarian reaction against the doctrine of governmental impotence to remedy unmerited distress, made supports of governmental inaction as a policy increasingly dangerous politically to any party which committed itself too strongly to it.

It was "evident that industrialization brought with it acute social distress which it was government's responsibility to alleviate" (Deane 1965:313). The pressure of the social question, i.e., the economic reality of a majority of society forced a social policy that supported the poorest of the poor. "The fact is that economic growth was not a process of steady improvement in standards of living for the mass of population" 
(Deane 1965:223). The industrial revolution did not lead to general abundance but the enrichment of a few, and the fast growing population, i.e. men's unrestricted desire and its fulfillment, was by far not the only reason for the poor condition of the workers. Instead of listening to the academic scribblers, politicians consequently followed the pressures of economic and political reality. 
3. Neo-classical Economics (1890s-1930s)

\subsection{The Victorian Boom}

... it is easy to realize the changes in the English intellectual climate which occurred after the Ricardian theory was formulated. The issue of unearned increments as connected with the agricultural rent had faded into the background. The rapid development of the mechanized industries, the incessant expansion of world trade, and the creation of an international capital market which was organized by English banks had greatly modified the structure of the English economy and had placed the manufacturing classes into the centre of economic interest. The relationship between employer and worker, especially in large-scale industries, had assumed new aspects. (Pribram 1983:301-302)

The British economy throughout the 19th century is characterized by growth: "growth became the normal condition of the economy, despite cyclical fluctuations, whose crises moreover contributed in the end to growth by eliminating the less efficient producers" (Crouzet 1982:102). The GNP showed growth rates of 2.2 to 3.3 per cent, the GNP per capita of 1.0 to 1.9 per cent throughout the century (Deane and Cole 1967:283). Especially the 1850 s and 1860 s were a period of relative prosperity for the British economy. The British national wealth increased from $£ 6.1$ billions in 1865 , to 10 billions in 1885, and 13.5 billions in 1900 (Dietz 1949:483). Only at the end of the 19th century British growth slowed down as result of declining trade, but it still was at about 1 per cent of GNP per annum (Floud 1994:4). "At the end of the nineteenth century Britain possessed the wealthiest and most powerful economy that the world 
had ever known" (Floud 1994:1). Also, the population still grew, from about 23 million in 1831 to about 40 million in 1911. However, due to declining birth rates the population growth rates were significantly lower than in the first half of the 19th century (Barnes 1994:29-30).

As Crouzet (1982) shows, the Industrial Revolution's basic results were savings in labor and gains in productivity. The latter led to a rapid and enduring fall in costs and in selling prices, especially after the end of the Napoleonic wars in 1815. This reduction in costs and prices had two consequences. First,

it speeded up the progress and spread of technology by encouraging the discovery and adoption of improvements that would again reduce costs and safeguard profit margins menaced by competition. ... It helped to give the Industrial Revolution its cumulative character and chain-reaction aspect. (Crouzet 1982:102)

Second, the cheaper manufactured goods were available to a wider and wider range of consumers. In the 1870 s there was a significant improvement of the situation of workers.

In 1840, according to the calculations of Arnold Toynbee, the wage of an ordinary laborer came to eight shillings a week, while his family necessaries of life cost him fourteen shillings; he made up the difference by begging, stealing, sending his children to the mills, or simply by drawing in his belt. But by 1875 , although necessaries had gone to fifteen shillings and a little over, his wages had nearly drawn abreast. For the first time he was making enough to keep body and soul together. (Heilbroner 1972[1953]:165) 
Also the hours people had to work were enormously diminished. For example, Heilbroner (1972[1953]:165) reports that the work week fell from sixty-one to fiftyfour hours in the shipbuilding and the chemical industry, and to fifty-seven hours in the textile industry.

Partly this betterment of the worker's conditions was due to the imperial spirit that was sweeping Britain in the latter decades of the 19th century. Between 1870 and 1898 Britain added four million square miles and 88 million people to its empire; "the colonies were now the proletariat's proletariat" (Heilbroner 1972[1953]:184-185).

According to Feinstein (1991), there was gradual progress in the standard of living from 1873 to 1900 , when real incomes were going up significantly. During this period one can see a rise in money-wages; however, this contributed to only one-fifth to the increase in real wages of about 55 per cent. The other four-fifths came from a decrease in retail prices.

The dominant influence on the progress of living standards ... was not the rise in nominal incomes but the long-run movement in the cost of living. During the last quarter of the nineteenth century the principal source of the sustained rise in the general standard of living of the working class was the strong downward trend of the cost of food, fuel and other necessities. (Feinstein 1991:151)

The same rule is true for the following years from 1900 to 1914, the beginning of the Second World War. This period encountered a rise of money-wages and an even higher increase in prices. Subsequently the standard of living fell-real wages dropped 
at a rate of about 7 per cent. Of course, the overall poverty in Great Britain was still enormously high, especially during depressions, when the declining profits led to mass unemployment. Dietz (1949:492) reports an average unemployment rate of 9.3 per cent in the period from 1873 to 1900 , with the largest figures of 22.2 per cent among the boilermakers and iron shipbuilders, 14.4 per cent among the blacksmiths, and 13.9 per cent among the ironfounders in 1886. It can be assumed that the (not available) figures for the non-unionized and unskilled laborers are higher.

A whole series of studies at the end of the 19th century revealed the living situation of the vast majority of British people (Dietz 1949:505-510). ${ }^{27}$ In 1883 Charles Booth investigated by going door-to-door the earnings, expenditures, and the conditions of life among the various classes in London. He showed that one-third of the population were on or below the line of poverty. The people in this group were the urban dwellers that shared one tiny room with one or more persons. The census of 1901 showed that in London two-thirds of the population lived in houses of not more than four rooms, with 392,000 dwellings in which 2.67 million ( 8 per cent of the population) people lived.

The conditions found in London were the same in all parts of England.

Ninety per cent of the actual producers of wealth had no home which they could call their own beyond the end of the week, had no bit of soil or so much as a room that belonged them, had nothing of value of any

27 Court (1965:283) reports that in the 1880s social surveys were administered for the first time in British history. They were focusing on the urban working class but examined workers in agriculture as well. These first social surveys were the "work of wealthy amateurs" and became eventually institutionalized. 
kind except so much old furniture as would go into a cart, had the precarious chance of weekly wages which barely sufficed to keep them in health, were housed for the most part in places that no well-to-do man would think fit for his horse, were separated by so narrow a margin from destitution that a month of bad trade, sickness, or unexpected loss brought them face to face with pauperism. (Dietz 1949:508)

At the beginning of the century 27 per cent of the population is believed to have lived in a state of more or less acute poverty (Floud 1994:11)). One can conclude with Floud (1994:9):

Britain between 1860 and 1914 was ... a rich country, growing richer year by year as its economy made ever more efficient use of the resources which were available to it, although the growth in efficiency was slowing down. Economic growth brought with it improvements in welfare ... but left behind a substantial residue of the population in poverty.

\subsection{The Marginal Revolution}

Neo-classical economics was effectively established from the 1890 s onwards and replaced "the fragmented, often vaguely-defined, philosophically-oriented analysis of the classical school" (Deane 1978:107). Alfred Marshall was the new school's most influential proponent. Neo-classical economic thought was the heir of the marginal revolution..$^{28}$ The term marginal revolution is used to refer to the nearly simultaneous

\footnotetext{
28 The marginal "revolution" was a process rather than an event. It "went unrecognized by those who lived through it. ... [it] was first announced in the late 1880s and (despite Marshall's endorsement in 1890) did not become a regular feature of histories of economic thought until well past the turn of the century" (Blaug 1973:8). See Stigler (1973) for a discussion of the adoption of marginal utility.
} 
but completely independent discovery in the early 1870 s by William Stanley Jevons (1835-1882), a British economist teaching in Manchester, Carl Menger (1840-1921), an Austrian economist who constituted the Austrian School of economics, and Léon Walras (1834-1910), a French economist who taught in Lausanne (Howey 1973:1524). "Marginal utility emerged when these three men, from different countries, coupled their ideas of wants or utility with a basic concept of the differential calculus" (Howey 1973:25). ${ }^{29}$ Based on the assumption that consumers and producers would naturally behave so as to maximize their satisfactions or profits in a competitive market, these economists discovered the principle of diminishing marginal utility or satiable wants.

Marginal utility means that "the value of each unit out of a homogeneous stock of goods is determined by the least important use that can be made of it, in other words, by the diminution in want satisfaction caused by its loss" (Pribram 1983:278).

Marginal utility analysis became the basis of neo-classical economics.

The basic logic of this approach gave to the analysis of political economy a degree of systematization unrivaled by the earlier classical writer. In so doing it marked the transition from 'political economy' to 'economics.' The suffix 'ics' is significant, for it decisively arrayed economics along with such subjects as mathematics and physics, as having a rigor equal to the formal and physical sciences. (Breit and Ransom 1971:8)

The application of marginal utility as analyzing tool involved a wide-ranging transformation of the characteristic methodology in economics from a more theoretical,

29 For a discussion of the reasons for the success of the new paradigm see Deane (1975:100-113). 
historical approach toward the heavy use of mathematics. This methodological change was followed by an altered, i.e. reduced scope of economics.

How can the capital stock be augmented and markets widened so as to increase the productivity of labor, physical output, and therefore, welfare? This was the essential macro-problem classical economists wanted to solve. The marginal paradigm emphasized subjective factors, demand, and economic consumption rather than classical questions of growth, supply, and distribution, which could not be dealt within marginal utility analysis. The neoclassical school saw the economic micro-problem as how to get an optimal result by allocating a given quantity of scarce resources among competing uses.

Briefly, the marginal analysis is designed to find the most efficient allocation of competing resources, of scarce means with alternative ends. At the optimum position marginal values are equalised, i.e. the gains to be derived from putting unit of a resource to one use exactly equal the losses involved in withdrawing it from another. ... Wherever diminishing returns are obtainable from putting a given unit of income or time or productive resources to a particular use the optimum result is obtained when values are equalised at the margin. Within the conventional assumptions of the marginal analysis it can be logically shown that perfect competition leads to equimarginal allocation of expenditures and resources. (Deane 1978:98)

The marginal revolution altered the problem orientation of orthodox economics significantly:

The focus of the marginal analysis was the market and the neo-classical theorists accordingly narrowed the scope of their subject matter so as to 
be almost exclusively confined to a study of market processes. Consequently, although individual neo-classical theorists may have been, and some certainly were, as strongly activated by political and social objectives as any of their predecessors among the classical economists, they concentrated most of their attention qua economics on abstract theoretical issues which had no immediate connection with the urgent contemporary questions of practical policy. (Deane 1978:99-100)

Prior to the 1870 s political economy was oriented toward contemporary problems and institutions, and was "dominated by controversies over policy" (Stigler 1965:19). The neo-classical economists got rid of all the philosophical questions of Smith's kind. They acquired a stricter sense of what was logically, rather than politically or morally relevant to explain economic phenomena. As trained professionals they developed the science of economics as we know it today: "economic phenomena abstracted into mathematical equations, curves, and graphs" (Preston 1967:39). This development mirrored that economics, over a century in existence by then, became a more rigorous science. "Marginalism both reflected and contributed to the process of professionalization and internalization of economics as an organized discipline which took place after 1870" (Winch 1973:60).

Writing at a time when "the separation of the economic and political orders was greatest" (Preston 1967:39), neo-classical economists detached themselves from questions of welfare and income distribution.

There was simply no longer any room in the official world of economics for those who wanted to take the whole burly gamut of human behavior for their forum, and there was little tolerance in the stuffy world of Victorian correctness for those whose diagnosis of society left room for 
moral doubtings or seemed to indicate the need for radical reform. (Heilbroner 1972[1953]:172)

In accordance with positivist claims of scientific, ethical neutrality, neo-classical theorists withdrew themselves from the political sphere. "... after utility theory began to appear in the 1870 's, it took no important part in any policy-oriented controversy up to World War I" (Stigler 1973:312). Mahoney (1985: 186-202) shows that marginalism and the positivist claim of ethical neutrality were allies.

On the one hand, economists cast in an increasingly scientific role, became both less interested in and more wary of a political one. ... On the other hand there was some inclination to make a virtue out of necessity; the relative inapplicability of neoclassical theory was best defended by an aggressive hostility to policy prescription by any economist. (Mahoney 1985:187)

However, an ethically neutral statement can still be ideologically biased. The problem of distribution, which had preoccupied the classical economists, was solved in marginal terms. The neo-classical utility theory of the optimum allocation of economic resources implied that the closer the economic system conformed to the operations of a perfectly competitive market the nearer it would come to an optimal distribution of incomes. Adam Smith's optimistic view in regard to the general wealth of nations comes to mind. Indeed, marginal utility analysis retained the classical bias toward economic individualism and laissez-faire and implicitly supported the political status quo. Breit and Ransom (1971:10) give three "cornerstones" that supported the laissez-faire 
policy-implications of neo-classical economic theory: the maximization of utility as the major economic problem, marginal calculations as analytical tool to solve this problem, and the concept of "economic man as the actor," a rational, calculating human being. Deane (1975:109-111) and Mahoney (1985:203-204) argue, that the ideological implications of neo-classical economics probably were the most important factor for the new school's triumph. ${ }^{30}$

British industry was faced with intensifying international competition abroad and increasing labour problems at home; the social and economic problems associated with an urbanised industrial economy seemed to call for a revision of traditional dogma concerning the role of government in the economy; the process of constitutional reform was extending the vote to the working classes at a point in time when the income gap between rich and poor was becoming, if not wider, at least more obvious. In these difficult circumstances, a methodology which took as its central exemplar a demonstration of the optimal allocation of scarce resources in a perfect market and substituted a 'scientific' concept of equilibrium for the out-dated philosophical assumption of the 'natural law' ... permitted economists to justify an ideological bias towards the status quo of income distribution on ostensibly non-political grounds. (Deane 1978:111)

Deane's and Mahoney's argument is the more convincing if one looks at the three possible alternatives in economic theory that were around in late-nineteenth cen-

30 Blaug (1968: 304-308) examined the origins of the marginal revolution. It would go to far for the context of this paper to describe his argument at length. But I want to point to one out of four historical explanations that has been used to explain the marginal paradigm's genesis and success-the argument that marginal-utility theory was "nothing but the bourgeois answer to Marxism" (Blaug 1968:307). Blaug demonstrates that this position cannot stand up to close scrutiny. Instead, as far as Britain is concerned, the marginal utility doctrine can be seen as an autonomous intellectual development "under the impulse of a growing sense of dissatisfaction with older [i.e. classical] views" (Blaug 1968:304).

For the related discussion of the fall of the classical economy in the last decades of the nineteenth century see Hutchison (1973). 
tury Britain: radical Marxist economic thought-Karl Marx had published the first volume of Das Kapital in 1867-, the German-Austrian Historicist School that advocated a state-directed economy, and classical Ricardian economics. ${ }^{31}$ The latter was discredited as it contained "socialistic implications so close to the surface as to make even an unembellished statement of the doctrine dangerous" (Mahoney 1985:205). These implications, e.g. Ricardo's statement that the interests of the landlords are always at odds with the capitalists and the workers, and his labor theory of value "suggested the rationale for an inherent capital-labour conflict" (Deane 1978:111). They became obvious at least by 1867 , when Marx had based his economic theorizing in Das Kapital on Ricardian assumptions.

\subsection{Alfred Marshall (1842-1924)}

The dominant influence on economic theory from the 1890 s to the depression of the 1930s, especially in English-speaking nations, was undoubtedly Alfred Marshall, the Cambridge economist who reaffirmed and extended the classical traditions ... His major work, Principles of Economics, published in $1890, \ldots$ seemed to many a definitive answer to the attacks against the classical writers that came from all sidesfrom the historical economists, the socialists, and the new marginal-utility theorists such as Jevons and the Austrians. (Burtt 1972:201)

31 Deane (1978:125-142) gives a good overview of Marx's contribution to economic thought and reasons for its low impact on orthodox economics. For a discussion of the Historicist school see Blaug (1968:501-573). 
The emphasis on allocation with maximum effect is stronger in the economic theories of Walras, Menger, and Jevons than in Marshall's. He "never entirely abandoned the deep-rooted classical belief that economic welfare depends as much on capital accumulation and population growth as on efficiency in resource allocation" (Blaug 1968: 300). Instead of general equilibrium he preferred a more developmental and less static, partial equilibrium analysis of economic phenomena in particular sectors. But overall Marshall "devoted more attention to the action of competition in tightening up the allocation of resources within a given market environment than to the expansion of the market area itself" (Blaug 1968:300).

Marshall was convinced that economics could play a major role in fostering economic understanding and, henceforth, economic and social progress. By deriving from marginal utility theory the concepts of consumer's and producer's surplus, Marshall hoped to make economics a basis for policy without compromising scientific standards and ideological neutrality. He thought that the possibility of ending poverty gave economic studies "their chief and their highest interest" (Marshall 1961[1890]:4). In fact, Marshall was coming from his morals and ethics to economics, "from his zeal to make a contribution to the social betterment of man" (Viner 1958:251). Marshall, a Cambridge scholar ${ }^{32}$, stated his motivation as follows:

It will be my most cherished ambition, my highest endeavour, to do what with my poor ability and my limited strength I may, to increase the numbers of those, whom Cambridge, the great mother of strong men,

\footnotetext{
32 Marshall received his degree in mathematics in Cambridge in 1865 . From 1885 to 1908 he hold the chair of political economy at Cambridge. (Burtt 1972:203, 205)
} 
sends out into the world with cool hearts, willing to give some at least of their best powers to grappling with the social suffering around them; resolved not to rest content till they have done what in them lies to discover how far it is possible to open up to all the material means of a refined and noble life. (Marshall 1925[1885]:174)

Viewing himself in the tradition of the classical economists, Marshall believed in a system of charity and goodwill, that could be enhanced by economics:

... nearly all the founders of modern economics were men of gentle and sympathetic temper, touched with the enthusiasm of humanity. They cared little for wealth for themselves; they cared much for its wide diffusion among the masses of the people. ... They were without exception devoted to the doctrine that the wellbeing of the whole people should be the ultimate goal of all private effort and all public policy. (Marshall 1890[1961]:47)

Marshall stated that he "practically completed" his "main position as to the theory of value and distribution" already in the late 1860s (Marshall 1961[1890]:416). That means that he began "to graft marginal utility analysis on to the Ricardian system" (Deane 1978:95) as early as Jevons, Menger, and Walras did. However he published the Principles about 20 years later. "... but by then he had been teaching economics for twenty years in Cambridge, Bristol and Oxford, and he had indoctrinated the inhabitants of half the economic chairs in England" (Deane 1978:102). His delayed book, which became the bible of the neo-classical school, went through eight editions which did not differ significantly from each other-the final one appeared in 1920: "... the 
view of economics presented in Marshall's first edition of the Principles remained relatively unchanged in subsequent editions" (Burtt 1972:205).

Burtt (1972:202-203) gives three reasons for the book's overwhelming success. First, it significantly contributed to the development of techniques of economic analysis in the marginal and the classical tradition. Even in his lifetime, contemporaries revered Marshall as the great reconciler of the deductive (marginal) and inductive (historical) methods. His bipartisan image rested on statements on induction and deduction like the following:

Each study supplements the other; there is no rivalry of opposition between them; every genuine student of economics sometimes uses the inductive method and sometimes the analytical, and nearly always both of them together. There is a difference in proportion between different students; as one may eat more solid food and another may drink more fluid; but every one must both eat and drink under pain of starving or dying of thirst. (Marshall 1925:309)

Second, not sharing his marginal utility colleagues's apoliticalness, Marshall applied his theories to everyday economic problems, especially the problem of poverty. Finally, Marshall explicitly wanted to develop an economic theory that supported the status quo by showing the relationship between a competitive economic structure and the economic and moral well-being of society. Viner (1958:246-261) supports this latter point. He makes the case that the British economist-even though he was sincerely concerned about the improvement of the conditions of the poor-represented 
the Victorian age of complacency, gentility, and optimism when looking at his stance toward people's general well-being. ${ }^{33}$

Marshall saw the still widespread poverty in Britain as a major problem, and identified its reasons within the process of economic development. For example, he stated that the early "capitalist employer ... was tempted to subordinate the wellbeing of his workpeople to his own desire for gain" (Marshall 1961[1890]:750). Marshall disapproved of the way the rich often tended to create envy by ostentatious displays. He noted that many of the "largest" fortunes were made by "speculation rather than by truly constructive work," by "anti-social" strategies, and even by "evil manipulation" (Marshall 1961[1890]:719).

Marshall believed that differences in economic status of the different social classes were for the most part due to inequality of opportunity and not a lack of ability and character, as the Social Darwinists ${ }^{34}$ argued at that time: "... the poverty of the poor [was] the chief cause of that weakness and inefficiency which are the cause of their poverty" (Marshall 1925/[1885]:155). Marshall attributed the "physical, mental, and moral ill-health" of the poor to their inadequate income, the type of work they did, and the squalid, overcrowded conditions in which they lived (Marshall 1961[1890]:2).

One must ask, if this analysis of the origins of poverty led Marshall to advocate reforms in order to relief the poor. Burtt $(1971: 210-211)$ aptly answers this question:

33 The "Victorian age" is named after the reign of Queen Victoria from 1837 to 1901.

34 For a good overview about social Darwinism and its spread see Hofstadter (1965 [1944]). 
In short, there was nothing fundamentally wrong with the institutions of the capitalist and the free-market system. ... Free enterprise, through an upward, evolutionary process, was substantially improving the material and moral well-being of the masses. Poverty and other social ills could be gradually eradicated by education and appeals to the chivalrous spirit of the rich, but the process required time and, above all, Marshall warned, no interference with the basic institutions of the system by the impatient with their collectivist schemes.

A paradox? Not to Marshall. He had a firm faith in the underlying benevolence of a system of free enterprise that he believed would gradually resolve the identified problems. In this regard, Marshall shared Smith's optimistic view about the enrichment of the people through economic progress.

He was confident that if only there were sufficient goodwill ('economic chivalry') and economic understanding substantial progress would in fact occur ... The progress he sought, moreover, was not to be merely a matter of more goods, but of access to and liking for a more leisurely and more refined life for all the people, so that even hod-carriers could be gentlemen. (Viner 1958:251)

Yet Marshall rejected restraints on the free-enterprise system, which he believed, would impair the rate of technological advance and investment essential to economic progress, as well as the free movement of resources necessary to achieve an optimum of allocation. "Natura non facit saltum" (Nature makes no sudden leaps) was the motto of the Principles, in other words, the betterment of the poor will come in a gradual, slow process, not eruptive and through reforms. ${ }^{35}$

35 This apparent inconsistency leads Maloney (1985:169) to call Marshall's writings on welfare economics as "theoretically unsatisfactory and practically inconclusive. The overall picture is of a categorised list of exceptions to the optimising behavior of the market ..." 
He voiced numerous objections to government ownership and operation of industry (Marshall 1925:323-335). His overriding objection to state interventions and restrictions was that it would choke off the inventiveness of the entrepreneur and hence impair economic growth: "... every great step in the direction of collectivism is a grave menace to the maintenance even of our present moderate rate of progress" (Marshall 1925:342). He decried arguments for "untried" social reforms on the grounds that the

rights of private property ... have been inseparable from solid progress; and that therefore it is the part of responsible men to proceed cautiously and tentatively in abrogating or modifying even such rights as may seem to be inappropriate to the ideal conditions of social life. (Marshall 1961[1890]:48)

Although Marshall was sympathetic to certain objectives of trade unions, he believed that they were harmful to the extent that they could impose wages different from the competitive market rate, place obstacles in the way of worker mobility, or limit technological innovation. In a letter dealing with an engineers strike in 1897, Marshall wrote:

I have often said that T.U.'s [trade unions] are a greater glory to England than her wealth. But I thought of T.U.'s in which the minority, who wanted to compete with others to put as little work as possible into the hour, were overruled. Latterly they have, I fear, completely dominated the Engineers' Union. I want these people to be beaten at all costs: the complete destruction of Unionism would be as heavy a price as it is possible to conceive: but I think not too high a price. (Marshall 1925:400) 
Marshall did not share Ricardo's pessimism. He did not believe that economic development would end in a stationary state and would reduce the standard of living of the vast majority of people to the subsistence level. However, Ricardo's and Malthus's influence on Marshall can be traced back in his writings. Marshall was convinced that a system of poor relief can only do good insofar it is restrained by sound general principles. He was searching for "means of reconciliation between advocacy of relief of distress on humanitarian grounds and adherence to the ... principle that it was urgent to preserve unimpaired by excessive charity the capacity for and the will to practice selfhelp on the part of the poor" (Viner 1958:254).

Marshall's optimistic turn is closely related to the historical background of his time (Marshall analysed and described the course of economic development in Appendix A of his Principles.). He argued that technological progress had made food so cheap that the pressure of population on food supplies had abated significantly. Technological changes in agriculture had reduced costs directly, and improvements in transport had "enabled Englishmen of the present generation to obtain the products of the richest lands of the earth at comparatively small cost" (Marshall 1961[1890]:180). ${ }^{36}$ Moreover, he recognized a tendency for those with higher incomes to have smaller families. ${ }^{37}$ Therefore, the possibility of restraining future population growth seemed to

\footnotetext{
36 This view is supported by Deane and Cole (1962:170) who report thath agricultural output may have doubled between 1800 and 1860 and stayed at this level from then onwards. Also, they see a sharp decline in agricultural proces from 1862, and especially from 1878 onwards (1962:343-345). 37 This was influenced by the possibility of family planning, as in the early part of the last quarter of the 19th century the first contraceptive methods were developed (Dietz 1949:483-484).
} 
him to be greatly improved as the economy became more and more productive and as more income reached the working classes.

Marshall saw the reasons for these positive changes in the growth of the free enterprise system that promoted technological change and an upward trend in real incomes. To him, three conditions were responsible for England's emergence as the world's leading industrial nation: first, the desire of the population for greater material comforts; second, the submission of "every action to the judgment of the reason", rather than custom in order to maximize income; and third, "complete political freedom and security" which enabled individuals to act in their own interest and "fearlessly" commit themselves and their property to "new and distant undertakings" (Marshall 1961[1890]:744). This third factor he regarded as especially important: "[The] same qualities which gave political freedom gave them [England and its colonies] also free enterprise in industry and commerce" (Marshall 1961[1890]:744). These "qualities" were essentially the moral virtues of applying one's energies to the invention and production of goods, of individualism and self-reliance, of forethought, and of the careful calculation of alternatives.

Marshall approved of certain types of protective legislation for women and children on the grounds that, since the nation seemed strong and wealthy enough to impose new restraints on free enterprise, it could absorb "some temporary material loss ... for the sake of a higher and ultimate greater gain" (Marshall 1961[1890]:751). He did not 
carry this argument very far, however; e.g. he opposed all minimum-wage legislation (Marshall 1961[1890]:715-716).

Marshall's answer to the problem of poverty was education and he encouraged a policy of "generous expenditure" for the education of the masses (Marshall 1961[1890]:43). His argument was that since an individual's discounted lifetime earnings equalled the cost of his training, poverty perpetuated itself through the failure of the poor to invest in the education of their male children ${ }^{38}$

The worse fed are the children of one generation, the less will they earn when they grow up, and the less will be their power of providing adequately for the material wants of their children; and so on to following generations. (Marshall 1961[1890]:562).

Thus he saw poverty as cumulative unless the chain of circumstances would be broken by public outlays to educate the children of the poor. Education would not only increase their skills; it should improve their tastes, their attitudes toward work, and their character:

... the schoolmaster must learn that his main duty is not to impart knowledge. ... It is to educate character, faculties and activities; so that the children even of those parents who are not thoughtful themselves, may have a better chance of being trained up to become thoughtful parents of the next generation. ... To this end must money flow freely. (Marshall 1961[1890]:178)

38 Marshall did not believe in the emancipation of women, but felt strongly that a woman's place was in the home, raising her children: "The most valuable of all capital is that invested in human beings; and of that capital the most precious part is the result of the care and influence of the mother, so long as she ... has not been hardened by the strain and stress of unfeminine work" (Marshall 1961[1890]:564). 
Furthermore, improvement of the moral climate was important to Marshall. He urged that businesses adopt fairer and more benevolent attitudes toward their employees and others, as he saw businessmen too much attached to the motive of financial gain for this marked their excellence. "And so all the best businessmen want to get money ... chiefly as the most convincing proof to themselves and others that they have succeeded" (Marshall 1925: 281). But the fact that many large incomes existed because of the desire to excel did not alter the waste and deprivation which accompanied maldistribution of wealth, so Marshall wrote:

Now there is general agreement among thoughtful people, and especially among economists, that if society could award ... honour, position and influence by methods less blind and less wasteful; and if it could at the same time maintain all that stimulus which the free enterprise of the strongest businessmen derives from present conditions, then the resources thus set free would open out to the mass of people new possibilities of a higher life, and of larger and more varied intellectual activities. (Marshall 1925: 328)

Marshall called this philanthropic approach, which emphasized the personal relationships between employers and their workers, and businessmen and the public "Economic Chivalry." This, he said, included not only public spirit, but also "a delight in doing noble and difficult things because they are noble and difficult ... It includes a scorn for cheap victories and a delight in succouring those who need a helping hand," and a pride in achievements "only in the second degree for the value at which they are appraised in the money of the market" (Marshall 1925:330-331). Unless such a spirit is 
developed, Marshall said, the "world under free enterprise will fall far short of the finest ideals" (Marshall 1925:342).

It can be summarized, that Marshall was a strong advocate of laissez-faire. He only ascribed few tasks, in particular education, to the state in regard of the welfare of the people. He did not oppose poor relief totally, however thought of it as being capable of reducing people's will to work hard and to help themselves out of their poverty. Hence, he did not see the necessity to extend existing laws. Additionally, he believed in "economic chivalry" that would help to alleviate widespread poverty. Overall, he was convinced that a free-market economy will eventually enrich people-if not all, at least the vast majority—and so clearly stands in Smith's tradition. The major difference between these two theorists is that Smith's optimism is based on his belief in a natural, harmonious order, whereas Marshall's laissez-faire approach is based on marginal utility analysis and historical demonstrations that showed a gradual improvement of the living standards in Britain (see below). This difference might be the reason for their different view of how many people could share the wealth of the nation. While Smith explicitly included everybody in the idea of general abundance, Marshall takes a more cautious position and wants to "discover how far it is possible to open up all the material means of a refined and noble life." 


\subsection{The Introduction of Collective Modern Welfare}

As I have already shown for the classical period, the neo-classical period was characterized by a significant gap between the policy implications that economists deduce from their theories and the actual policies. In contrast to the laissez-faire approach of neo-classical economists that was based on an optimistic picture of a free enterprise economy that will lead to broad abundance, British politicians started to introduce a modern welfare system in the last decades of the 19th century.

Court (1965:361-368) describes the path Britain took in the 19th century from an individualist society to one that supported concepts of collective welfare. Until the 1870s the individualist doctrine was that "it was man's duty to provide for himself and all his dependents, both for the ordinary purposes and the contingent risks of life, including sickness and the want of work, old age and death" (Court 1965:361). Holmes (1976:199) supports this view: "... attitudes in the early nineteenth century towards poverty tended to be primitive and the assumption was that poverty arose from lack of will to work. Self-help was the answer to material affliction." The individualist doctrine, which "extended deep into the nation" (Court 1965:362), reflected the beliefs of the political leadership of the Victorian age-the landowning classes in the country and the commercial and industrial middle and upper classes in the towns and cities.

Except for some voluntary institutions of and for the working class such as mutual clubs, insurance societies, savings banks, and trade unions with a benefit plan, 
and the above described Poor Laws of $1795 / 96$ and 1834 , there were no collective efforts to absorb the uncertainties of economic life. Instead many men "genuinely believed that in creating his family income a man had discharged all his obligations to the community, owing nothing more to it and the community nothing to him" (Court 1965:363).

In the 1880 s this widely held view of economic individualism came to and end. Backed up by the social studies (see above) that revealed the scope of poverty "it was difficult to maintain that poverty was solely due to personal deficiencies, and attention was drawn to the social defects implicit in existing economic arrangements" (Holmes 1976:200). So the individualist doctrine was replaced by a new idea that represented a further phase in the development of social welfare:

This was the belief that somewhere or other existed a standard of what the basic elements of a civilised life ought to be, that standard could be found and than when found laws and custom should enforce it. ... if individuals did not possess the income necessary to purchase these indispensable elements of a decent existence for themselves, then it would be right and proper for the community to use its authority $(a)$ to see whether an adequate income could not somehow be found for them in the market, $(b)$ to direct income, via taxation, from the more fortunate citizens towards those who tended to fall below the minimum. (Court 1965:366)

The implied state interventions of the new belief went far beyond the still existing Poor Law from 1834, that was dealing en bloc with all the economic risks. Subsequently, this Poor Law was replaced by single-purpose social policies, each covering a 
chief economic risk of workers and their families: the employer's liability laws (1894, 1897) rendered the employer liable for work accidents of his workers, old age was dealt with non-contributory state pensions (1908), for cases of sickness a contributory national insurance was created in 1911, and legislation in 1905, 1909, and 1911 dealt with the problem of unemployment by creating a national insurance as well, which supported jobless workers with unemployment benefits from 1913 onwards. ${ }^{39}$ Of course, this legislation was not revolutionary in its monetary output. "... the effects until 1914 were small" (Holmes 1976:200) as few people were eligible for the benefits of the new laws. But the symbolical character was tremendous as it signalized the departure from laissez-faire and the recognition of the responsibility for the social welfare of its people of the state.

Moreover, besides creating these social services, the state "recognized for the first time since $1813^{40}$ a certain responsibility for the level of wages" (Court 1965:367) by passing the Trade Boards Act of 1909. In 1908 and 1911 laws were passed in the coalmining industry regulating the length of working hours and the wages for miners. These laws were "the first intervention of the state in the internal economy of a large industry" (Crouzet 1982:108). A housing act improving housing conditions passed Parliament in 1890 , education acts $(1870,1876,1891)$ forbade children under thirteen to work, introduced compulsory elementary education, and abolished fees in public

\footnotetext{
39 For the detailed regulations of these new policies see Dietz (1949:527-528) and MacKinnan (1994:289-290).

40 "The machinery for minimum wage regulation disappeared in 1813 with a repeal of the wages clauses of the Act of 1563" (Chambers 1961:193).
} 
schools (Dietz 1949:509, MacKinnan 1994:289). The state seemed to recognize its responsibility to invest in human capital and manifested this with increasing expenditures for education-in 1870 the government spent $£ 1.62$ million for this sector, in $1910 £ 17.9$ million, in $1938 £ 63.1$ million, local authorities contributed $£ 2.2$ million in $1875, £ 27.5$ million in 1910 , and $£ 505.6$ million in 1938 (Holmes 1976:197).

All these social policies cost money and the state reacted by imposing taxes on the more wealthy people, i.e. by redistributing wealth. At the beginning of the twentieth century "the principles of graduated and progressive taxation" were developed for "earned" and "unearned" income, and new taxes "were laid on the land, machinery, mineral rights, motor cars (...), and gasoline" (Dietz 1949:526-527). So the state doubled its income in only five years: in 1908 it made $£ 100$ billion, in 1913 already $£ 200$ billion.

Court (1965:363-366) gives two causes for the decline of the doctrine of economic individualism and its replacement by the beginnings of the modern welfare state. Both causes were direct consequences of the industrialization of the country. First, he argues, the continued decline of the older social ties of family and locality put a great strain on the doctrine. The condition of most workers in the urban industrial areas was characterized by a "lack of security" and a "dependence on their jobs in an unstable and fluctuating order" (Dietz 1949:493). For example, old people, who were not able to work any more and to make a living, and who did not have relatives or neighbors which could support them, as it was usual in the pre-industrial, traditional society, became a 
major problem of towns and cities. In contrast to the apparent wealth of the country and of some of its citizens these inhuman features raised questions how to make the workings class's living situation more secure.

The second cause for the dissolution of economic individualism was "the reverse and more positive side" of the former cause-"the emergence of new forms of community life and a new scale of social values" (Court 1965:364). Three institutions were the major force behind this transformation of social life: the cities, collective bargaining between trade unions and employers in order to find minimum standards of wages, hours, and conditions of work, and changes in the national administration. The cities and towns at that time went through a period of expanding local governments that "began in the last thirty years of the nineteenth century the business of leveling up living standards" and "worked towards the recognition of a right to the provision of a minimum of welfare" (Court 1965:365). Also, public funding of services and utilities such as gas, water, local transportation, and harbors started in the 1880 s, taking this tasks away from private enterprise (Holmes 1976:198).

Treble (1991) and Court (1965:318-324) give a good overview of the emergence and gain of bargaining power of the trade unions. ${ }^{41}$ Toward the end of the nineteenth century they "reached a condition in which they could write a contract concerning wages and conditions of employment and also have equal recourse with employers to the law in enforcing such a contract" (Treble 1991:218). Three acts

\footnotetext{
41 The British labour unions became a common organization in 1868 , when they formed the Trades Union Congress. From then onwards they achieved considerable political influence. (Holmes 1976:56)
} 
(1867, 1874, and 1875) granted trade unions full legal recognition and broad opportunities for industrial action (including strikes). Throughout the 19th century trade unions and their leaders fought for such a status, which was for the most part illegal due to Combination, Arbitration, and Master and Servants Acts that operated in the laissez-faire spirit of the age and in favor of the employers. In the long run, Treble and Court argue, these regulations could not be upheld, as the working class developed a social self-consciousness and strongly supported the trade unions and was sympathetic with socialist ideas. In 1842 , trade unions had about 100,000 members, in the 1870 's about one million, in 1900 over two million, and by 1914 over four million workers were registered, that was about 30 per cent of the male work force (Court 1965:320). ${ }^{42}$ Socialist ideas began to play a role in British politics for the first time in the 1870's and the grouth of its influence on politics and public opinion was rapid (Court 1965:364).

At the end of the 19th century, the British administration and the civil service encountered several changes in Max Weber's sense of "bureaucratization" that increased their efficiency and ability to impose and survey its laws and orders. A whole new system of social welfare, based on the belief in minimum standards of living, was created (see above). In 1867, with the establishment of the second Reform Act, almost every male adult became eligible to vote in Britain (Viner 1958:249). The general suffrage and the socialist danger are regarded as a major cause for the shift in social policy toward a social welfare state.

\footnotetext{
42 The changes in legislation in regards to trade unions and the high membership figures resulted in a high coverage of collective agreements. Court (1965:322) reports about 2.4 million workers, i.e. about a quarter of the employed population, to be covered in 1910.
} 
... it became necessary for both the Aristocratic Conservative or Tory party and the by-now predominantly middle-class Liberal party, if either were to gain or retain power against the other, and if a third and 'subversive' working-class party, as strong as or stronger than they, was not to come into being, to woo the working classes by support of a policy of wider governmental activity on relief of distress and poverty. Social reform through legislation thereafter became respectable political doctrine for both parties, and reform legislation in fact obtained active support alternately or simultaneously from both major parties during the remainder of the century. (Viner 1958:249)

The formation of a working-class party could not be avoided. In 1901 the Labour party, "compounded of trade unionist workers and the intellectual socialists" (Dietz 1949:482-483, 509-510), entered the political scene, and increased the pressure on the two established parties to introduce extensive programs of social reform.

Further interpretations hint at fears of economic decline and military defeat as reasons for the introduction of social policies:

Some of the interest of innovation arose from the perception that Britain's relative economic position was slipping. Fears that the working classes were suffering 'physical deterioation' were widespread ... If the working classes were not strong enough to work (or to fight for their country), Britain's prospects were bleak. (MacKinnan 1994:289) 
4. Keynesianism (1930s-1970s)

\subsection{Two World Wars and The Great Depression}

The British economic structure of the late 19th and early 20th century was a poor inheritance for the later 20th century. An increasing commitment to the world economy—according to Holmes (1976:37) Britain provided 29.9 per cent of world exports of manufactured goods in 1913 (in comparison the United States 12.6 per cent)-concentrated the British economy on the production in a few areas for which the market and technological prospects were not bright, such as textiles, agriculture, net property income from abroad, domestic service, and manufactured gas production and distribution. Industries with strong growth potential-chemicals, engineering, instrument production, paper and printing, electricity, telecommunications, construction and construction materials-were widely neglected (Holmes 1976:36-39). The British economy still did pretty well in the years until the First World War, with 1.1 per cent growth per year from 1899 to 1913 (Holmes 1976:38). But with the stagnation and collapse of the world economy in the years between the world wars, especially during the Great Depression between 1929 and 1933, the consequence of this overcommitment to worldwide trade was persistent mass unemployment.

Such unemployment symbolised in very real measure the difficulties which were being experienced in the 'older' industries of coal, textiles, 
iron and steel and shipbuilding. The common feature of those industries lay in their vulnerability to over-production or competition in world markets (Holmes 1976:113).

In turn, unemployment cleared the ground for the acceptance of the ideology of the welfare state and Keynesian economics for a generation or more after the ending of the Second World War. Reforms were only halted by the advent of Mrs. Thatcher's economic policies in 1979.

During the First World War unemployment was a negligible problem, but by 1920, when nearly every European nation adopted mercantilist, self-sufficient policies, it became a dramatic issue with the highest unemployment rates since 1870 , in particular in the coal, iron, steel, and cotton industries. Within four months the unemployment figure rose from 300,000 people (August) to 750,000 (December), and it reached its peak in 1922 with 2 million people ( 15 per cent of the work force); throughout the 1920s the figure never went below 1 million, or 9.2 per cent (Dietz 1942:547, Holmes 1976:113). However, the unemployed people "were being provided with at least a minimum standard of comfort" (Dietz 1929:554) by the unemployment insurance, which was extended in 1920 (see below).

Despite the mass unemployment the 1920 s were a period of prosperity for Britain. This view is supported by figures of the national income per head at prices from 1913 to 1914 -even though the figures dropped somewhat from $£ 50.27$ in 1914 to $£ 47.72$ in 1920 , to levels of about $£ 43$ in the following three years, from 1924 
onwards there is a constant rising trend up to $£ 51.46$ in 1929 (Deane and Cole 1967:330-331).

There was no even distribution of income or of the increases in income. The rich in 1929 were richer than they ever were, even though some who had formerly been rich were now badly off. The working classes were, however, generally speaking, better off than they had ever been. Wages were on a higher level than they had been in 1913; and as a result of the fall in wholesale prices by about 20 per cent between 1924 and 1929 real wages were tending to go up. The rise was estimated at between 5 and 10 per cent between 1924 and 1929. The general picture was that of trade activity and velocity of turnover greater in 1929 than in 1913 or even in 1919. (Dietz 1942:555)

By October 1929 excessive stock market speculation was followed by the Wall Street collapse and the capitalist world of America and Europe ran into the Great Depression, which abruptly ended the vision of general abundance until at least the end of the Second World War. "The vision of Every Man a Wealthy Man had been shown up as an hallucination" (Heilbroner 1972[1953]: 242).

In the 1930s the problem that dominated the mature capitalist economies was the problem of intense, persistent, trade depression, associated with widespread, unprecedentedly heavy unemployment. The unemployment problem was already chronic in Britain and some other Western European countries in the 1920s. By the 1930s it was universal in capitalist economies; and it was aggravated rather than relieved by laissez-faire economic policies. (Deane 1978:175)

British exports declined by 18.4 per cent between 1929 and 1930, and were exceeded by a fall of 23.5 per cent in the following year (Holmes 1976:126). In July 
1929, 1.1 million British were unemployed — by January 1930 the number had risen to 2 million, and it "mounted rapidly to 3,000,000" (Dietz 1942:569). However, in contrast to the American experience, the British managed to maintain of the unemployed (see 4.3). Overall the impact of the depression was not as disastrous as in the United States. From 1933 to 1940 the British economy recovered from the crash in an astonishing manner, measured by the level of productive activity. The net national income, at its lowest point in 1932 with $£ 3.6$ billion, shows a steady increase until 1940 , when it amounted to $£ 7.2$ billion (Deane and Cole 1967:244). The old, trade-focused industries became more efficient and less important, as capital investments were turned toward the new industries (Holmes 1976:137). Via economic policies the British government managed to transfer resources from production for export to production for the home market.

The importance of foreign trade in the economy was declining, the ratio of net exports to national income falling from 17 per cent in 1929 to 11 per cent in 1937 while the ratio of retained imports to income fell from 23 per cent to 18 per cent in the same years ... The recovery in Britain after 1932 was thus a home market recovery par excellence. (Richardson 1967:44)

However, the social defects prevailed. British unemployment rates began falling in 1933 and were down at 14.4 per cent in 1935, but still, "Average employment in Britain continued to run at levels of over 10 per cent except in 1937 when the level was 9.5" (Holmes 1976:133). 
The outbreak of the Second World War in 1939 brought the Great Depression to a sudden end. During the war Britain was transformed from a predominantly free market economy into a centrally managed economy. National net expenditure on warrelated activities increased form a mere 7 per cent in 1938 to a peak of 55 per cent in 1943, governments expenditure rose dramatically from 16 per cent of all net expenditure in 1939 to a peak of 64 per cent in 1943 (Howlett 1994:1). There was a massive increase in real output in Britain by 31 per cent in four years from 1938 to 1942 . Full employment was achieved almost over night. Employment increased by nearly 20 per cent from 1939 to 1943 . "This represented a dramatic illustration of just how many additional resources could be mobilised under the influence of buoyant demand" (Bleaney 1985:81). Recognition of this fact influenced academic and policy-circles as well as public opinion about how to ensure the maintenance of high employment conditions after the war (see 4.2).

\subsection{John Maynard Keynes (1883-1946)}

The first three decades of the 20th century were the historical context in which John Maynard Keynes, son of the classical economist John Neville Keynes and student of Alfred Marshall, developed his economic theories. His major economic work, The General Theory of Employment, Interest, and Money, which revolutionized orthodox 
economics was first published in $1936 .{ }^{43}$ It "received more attention than Alfred Marshall's Principles of Economics had received in over fifty years" (Pribram 1983:496) in only the first decade after its appearance. The mass unemployment during the $1920 \mathrm{~s}$ and 1930s revised the dominant neo-classical political and social attitudes and brought the problems of welfare economics back into the discussions of economic theory.

It was the unemployment that was hardest to bear. The jobless millions were like an embolism in the nation's vital circulation; and while their indisputable existence argued more forcibly that any text that something was wrong with the system, the economists wrung their hands and racked their brains and called upon the spirit of Adam Smith, but could offer neither diagnosis nor remedy. Unemployment-this kind of unemployment-was simply not listed among the possible ills of the system; it was absurd, impossible, and paradoxical. But it was there. (Heilbroner 1972[1953]:244)

Analyzing the ups and downs in the economy, or business cycles, Keynes realized that the neo-classical equilibrium theory is far from reality and inadequate to describe the current economic situation. "With the Great Depression of the 1930s ... the happy confidence in self-correction gave way to an embarrassing, then frightening realization that the self-regulating market ... had a flaw" (Preston 1967:40-41). He viewed the General Theory as necessary break with classical and neo-classical theory:

... the postulates of classical theory are applicable to a special case only and not to the general case, the situation which it assumes being a limit-

\footnotetext{
43 The General Theory built on several earlier articles that already contained Keynes's critique of the classical and neo-classical school and alternative views how to analyze the economy. Among the most important are The End of Laissez-Faire (1972[1926]), A Treatise on Money (1971[1930]), Economic Possibilities of Our Children (1972[1930]), and The Means to Prosperity (1959[1933]).
} 
ing point of the possible positions of equilibrium. Moreover, the characteristics of the special case assumed by the classical theory happen not to be those of the economic society in which we actually live, with the result that its teaching is misleading and disastrous if we attempt to apply it to the facts of experience. (Keynes 1965[1936]:3) 44

According to Deane (1978:182-185) there are three major differences between Keynes's economics and the classical and neo-classical schools that revolutionized orthodox economics-his central question, the model he uses, and his conclusions. Keynes's major concern was to find a diagnosis of and a remedy for the regularly occurring recessions that led to high unemployment rates. The general question Keynes addressed in his macroeconomics was what the determinants of the supply and demand were for aggregate output, or, more concretely, to "discover what determines at any time the national income of a given economic system and (...) the amount of its employment" (Keynes 1965[1936]:247). In contrast, the neo-classical school focused on microeconomics and hence hardly considered the problem of unemployment: " .. almost no economist after 1870 considered the type of macroeconomic problem with which Keynes was concerned" (Blaug 1968:662) and "... the striking characteristic of British economics in the 1920's was the lack of concern over unemployment and the failure to realize its extent" (Blaug 1968:661).

Keynes analyzed national income and unemployment by creating an aggregative model of the economy as a whole. His findings were "the nub of the Keynesian heresy"

\footnotetext{
44 Keynes attacked "classical" economic theory, by which he meant "the followers of Ricardo, those, that is to say, who adopted and perfected the theory of the Ricardian economics, including (for example) J. S. Mill, Marshall, Edgeworth and Prof. Pigou" (Keynes 1965[1936]:3).
} 
(Deane 1978:182). Based on the economic reality of his day and his economic model he argued that there was no self-adjusting mechanism of the economic system, and that only state intervention in the economy could create a general equilibrium. He abandoned the still prevalent doctrine of laissez-faire. In his theory there was "no invisible hand translating private self-interest into social benefit" (Deane 1978:182).

It is not true that individuals possess a prescriptive 'natural liberty' in their economic activities. There is no 'compact' conferring perpetual rights on those who have or on those who acquire. The world is not so governed from above that private and social interest always coincide. It is not so managed here below that in practice they coincide. It is not a correct deduction from the principles of economics that enlightened selfinterest always operates in the public interest. Nor is it true that selfinterest generally is enlightened, more often individuals acting separately to promote their own ends are too ignorant or too weak to attain even these. (Keynes 1972[1926]: 287-288)

His analysis of economic processes gave a theoretical basis for state intervention in order to fulfill the capitalist promise of wealth for everybody.

According to Keynes, the major problem with neo-classical economics was its employment theory that believed that a free enterprise economy would tend toward full employment (Keynes 1965[1936]:2-22). ${ }^{45}$ Second, Keynes took issue with the law of markets by the French classical economist Say (Keynes 1965[1936]:26). Say's law, which ran "like a red thread through the entire body of classical and neo-classical the-

\footnotetext{
45 As shown above, the vast majority of neo-classical economists did not consider such macroeconomic questions at all, as the utility analysis did not provide the economists with a measure for such problems. However, there were a few economists that dealt with that question. Blaug (1968:657-661) gives an overview of the neo-classical views and Keynes's interpretation and critique of the "classical" unemployment theory.
} 
ory" (Harris 1948:105) and on which the neo-classical full employment assumption rested, stated that for the economy as a whole, supply necessarily created a demand of equivalent magnitude. In other words, it denied that there can ever be a shortage of demand in relation to production. The only cures for unemployment, in the view of the neo-classical model, were "wage-cutting and an easy-money policy" (Blaug 1968:653). The possibility that inadequate demand could be the cause of unemployment was brushed aside. Neo-classical theory indicated that persistent unemployment could only be a result of some barrier to the fall in the money wage, namely, the refusal of workers to accept cuts in their real wage. Such unemployment was interpreted as voluntary unemployment. All other unemployment was interpreted as frictional, i.e., temporary unemployment due to the fact that it usually takes some time to find a new job or a new worker, even if both are available. Keynes dismissed this unemployment theory as unrealistic and introduced a new category of unemployment-involuntary unemployment, prevalent especially in periods of depression (Keynes 1965[1936]:22).

In contrast to the neo-classical theory that cuts in real wage are followed by full employment, Keynes, in the light of his own theory, argued that wage cuts would lead to a fall in income, hence to a fall in aggregate demand, and finally to an even higher rate of unemployment (Lekachman 1966:107-108). 
In Keynes's theory (1965[1936]:245-247) the level of employment and the national income depends on four criteria: the propensity to consume, the marginal efficiency of capital, the quantity of money, and the level of wages. ${ }^{46}$

The key factors in the system were (a) the 'principle of effective demand' which acted through the propensity to consume and the rate of new investment to set a ceiling to the level of economic activity, and (b) the role played by money as 'the link between the present and the future' in reflecting past and present uncertainties about the future of lenders and borrowers, and reflecting them on the rate of interest and hence of investment. The system was enriched by the introduction of a set of concepts ... viz the marginal propensity to save and its inverse the multiplier, liquidity preference ... and the marginal efficiency of capital .... (Deane 1978:179-180)

In short, the amount of employment and national income depend upon consumer demand which, in turn, depends upon the disposable income or purchasing power people have. The kernel of Keynes's theory of effective demand rests on his notion of the consumption function (Keynes 1965[1936]:23-34). That is, as income increases and consumption rises, the latter increases less than does the former, i.e., people save some of the higher income (Keynes 1965[1936]:96). Thus, said Keynes, the volume of investment must be constantly increased in order to maintain a full employment level (Keynes 1965:248-253). Since Keynes believed that consumption patterns are largely fixed, the level of employment and the amount of national income, given the consumption function, depended upon investment. In the ideal case, so

\footnotetext{
46 For another arrangement of the same factors or variables in Keynes's economic model see Pribram (1983:498), who points out that the propensity to consume, the liquidity preference, and the propensity to invest are fundamental psychological variables.
} 
Keynes, the investment rate would be as high as the savings rate- this would be the equilibrium case of full employment. Further Keynes analyzed that the demand for investment goods was largely autonomous, in the sense that it was independent of purchasing power of income (Keynes 1965[1936]:248). He saw that there were no institutional devices in use that could adjust the amounts actually invested to the amounts saved and available for investment. In light of his analysis that throughout economic history there has been a tendency to save more than to invest he viewed this lack as unfortunate (Keynes 1965[1936]:347).

Applying his economic model, Keynes analyzed that it was possible in a modern, industrialized nation that the balancing and regulating mechanisms of the market were capable of achieving equilibrium at a level that would leave a large portion of the labor force unemployed permanently. "... the economy can be established at various levels of employment of the available resources and ... full-employment equilibrium is but a single case out of a wide variety of economic conditions" (Pribram 1982:497). Worse yet, these same mechanisms, if uncorrected, so Keynes, tended to bring to a halt any economic boom and to turn the economy downward. So he saw the self-regulating market as able to regulate itself into stagnation. Such a stagnation of indefinite duration could happen when reduced total income, caused by reduced investment would eventually lead to reduced savings. The decline of savings would continue to a point at which all savings were invested, and stable total expenditures would be adjusted to sta- 
tionary total incomes (Keynes 1965[1936]:313-332). This analysis is aptly described by Heilbroner (1972[1953]:262):

Rather than a seesaw which would always right itself, the economy resembled an elevator: it could be going up or down, but it could also be standing perfectly still. And it was just as capable of standing still on the ground floor as at the top of the shaft. A depression, in other words, might not cure itself at all; the economy could lie prostate indefinitely, like a ship becalmed.

To avoid such a scenario (as it was happening in the 1930s), Keynes saw state intervention in the form of monetary and fiscal policies, which would influence and manage the level of effective demand, as a necessity.

If the forces operating in the exchange economy could not be relied upon to establish full-employment equilibrium, pursuance of an appropriate economic policy appeared to be indispensable in order to prevent the disintegration of a decaying economy. (Pribram 1983:498)

Keynes insisted on the importance of effective demand for the maintenance and expansion of economic activity (Keynes 1965[1936]:32). As a long-term wage policy, he recommended a combination of rising wages and stable prices which, assisted by the effects of technological improvements, would secure participation of the workers in the fruits of enhanced productivity and lead to the transfer of workers from less productive to more productive processes. As very concrete governmental tasks he demanded three interventions: in order to offset the decline in the propensity to consume, Keynes 
proposed the imposition of steeply progressive income taxes that would redistribute wealth; he recommended the maintenance of low interest rates as monetary policy; and finally he regarded issuance of public loans and execution of public works programs as important elements of a "socialization" of investment activities (Keynes 1965[1936]:374-378). This last measure is a cornerstone of Keynes's theory, as he proposed this policy especially during depressions when the government should practice deficit finance by spending on public works (Keynes 1959[1933]:128-131). ${ }^{47} \mathrm{He}$ stated the positive effects of public works already in The Means to Prosperity (1959[1933]). Imagine, he suggested, the government spent $£ 500$ extra and this sum sufficed to afford employment for one more person for one year in the construction of public works. Beyond the primary benefit of employing one more person, Keynes anticipated additional employment: "... the increase of employment does not stop there. The additional wages and other incomes paid out are spent on additional purchases, which in turn lead to further employment" (Keynes 1933[1959]:13). More yet could be expected: "The newly employed who supply the increased purchases of those employed on the new capital works will, in their turn, spend more, thus adding to the employment of others; and so on" (Keynes 1933[1959]:14). Keynes guessed this multiplier effect to 1.5 , that is, for every two men directly employed in consequence of increased government spending, a third man would be additionally employed. Further-

47 Keynes was not the first British theorist that advocated public works. According to Blaug (1968:654-656) there was only one economist in the 1920s that opposed this policy. What was new and made Keynes to an outstanding economist was that his policy recommendations "emerged out of a consistent macroeconomic model of the economy" (Blaug 1968:662), which the others did not provide. 
more, there were several budgetary and fiscal benefits from public works expenditures, argued Keynes.

Keynesian macroeconomics does not explicitly argue for welfare state measures, but Keynes's advocacy for redistribution of income and wealth in order to enhance demand of the poorer classes implies a welfare state.

Keynes's policy prescriptions are regarded as the principal reason for the General Theory's overwhelming international success among economists and politicians of all colors. According to Pribram (1983:496) the book's impact on Anglo-Saxon economic thought and on policies can only be compared with Adam Smith's Wealth of Nations. Deane (1978:184-185) writes:

... the time was ripe. Its abstractions seemed more relevant to the conditions of the 1930s than the competing theories. Its analysis gave a theoretical basis for policy-prescriptions that were more in tune with existing political trends in a world that was already in massive retreat from a laissez-faire ideology.

In light of the apparent failure of neo-classical economics to analyze the economy and socialist threats of a totally state-directed economy, Keynes moderate policyprescriptions were willingly embraced. Keynes was not advocating state intervention to a degree that they would abolish the free enterprise system in favor of a socialist economy (Keynes 1965[1936]:379). He envisioned a government that would play "a very large and useful role in the economic order and still preserve the freedom of individual decisions on investment, production, and consumption that a capitalistic order 
requires" (Preston 1967:40). Still relying on the classical and neoclassical tradition, Keynes's theory promoted an economy that was "ruled by the principles of free competition and profit maximation" (Pribram 1983:498).

In the last chapter of the General Theory with the title Concluding Notes on the Social Philosophy Towards Which the General Theory Might Lead, Keynes (1965[1936]:372-384) summarized his central concerns that, he believed, could be solved with his theory: economic efficiency, social justice, and individual liberty. As far as economic efficiency was concerned, he argued that decentralized market processes did an adequate job in determining what and how something was produced: "I see no reason to suppose that the existing system seriously misemploys the factors of production which are in use. ... It is in determining the volume, not the direction, of actual employment that the existing system has broken down" (Keynes 1965[1936]:379). However, so Keynes, the market mechanisms did fail in that they led to a socially inequitable distribution of income and wealth. "The outstanding faults of the economic society in which we live are its failure to provide full employment and its arbitrary and inequitable distribution of wealth and incomes" (Keynes 1965[1936]:372). Therefore, he thought that social justice would be best served by state intervention that would guarantee an adequate volume of employment and a more fitting distribution of wealth. As far as individual liberty is concerned, Keynes retained a strong belief in individualism, by which he meant a decentralized relative autonomous market: 
But, above all, individualism, if it can be purged of its defects and its abuses, is the best safeguard of personal liberty in the sense that, compared with any other system, it greatly widens the field for the exercise of personal choice. It is also the best safeguard of the variety of life, which emerges precisely from this extended field of personal choice, and the loss of which is the greatest of all losses of the homogeneous or totalitarian state. For this variety preserves the traditions which embody the most secure and successful choices of former generations; it colours the present with the diversification of its fancy; and, being the handmaid of experiment as well as of tradition and of fancy, it is the most powerful instrument to better the future. (Keynes 1965[1936]:380)

However, he went on to defend his argument for governmental intervention as necessity despite its seemingly negative effects on individualism:

Whilst, therefore, the enlargement of the functions of government, involved in the task of adjusting to one another the propensity to consume and the inducement to invest, would seem ... to be a terrific encroachment of individualism. I defend it, on the contrary, both as the only practicable means of avoiding the destruction of the existing economic forms in their entirety and as the condition of the successful functioning of individual initiative. (Keynes 1965[1936]:380)

Putting himself in the classical tradition that advocated a free economy and the calming effects of acquisitiveness, Keynes believed that there were "valuable human activities which require the motive of money-making and the environment of private wealth-ownership for their full fruition" and that "dangerous human proclivities can be canalized into comparatively harmless channels by the existence of opportunities for money-making and private wealth" (Keynes 1965[1936]: 374). On the other hand, "it is not necessary for the stimulation of these activities and the satisfaction of these pro- 
clivities that the game should be played for such high stakes as at present" (Keynes 1965[1936]:374). Thus, he held that "it may still be wise and prudent statesmanship to allow the game to be played, subject to rules and limitations" (Keynes 1965[1936]:374).

Keynes saw capitalism as an appropriate system to provide general abundance, though not without considerable doubt as to its virtues, and with the proviso that meaningful reforms and controls be undertaken that influence the aggregate propensity to consume and invest, i.e. effective demand. That Keynes actually was very optimistic about the future becomes clear in his essay, Economic Possibilities for Our Grandchildren (1972[1930]). Herein he stated that by the year 2030 the economic problem of scarcity would have been solved due to an ever-increasing productivity. If the economy would develop at the same pace as in the last 100 years, Keynes calculated, England's real productive wealth would multiply by seven and one half times in the next 100. With help of his policy recommendations the result would be general abundance.

\subsection{Keynesianism applied}

In the neo-classical period one of the new social policies which were based on a changed view of collective responsibility for economic risks was the introduction of unemployment insurance in 1911. In accordance with the neo-classical economists 
who had only voluntary and frictional unemployment in mind when talking about this social issue, the kind of unemployment the legislators wanted to cover with this policy

was seasonal and cyclical. It was not the unemployment proceeding from structural change in industry and its markets which became the unemployment problem of the 1920's and 1930's. Nor was there for another generation after 1911 any question of the State assuming a general responsibility for the level of employment and the use of national resources. (Court 1965:367)

As shown above, as the "... ideological bias associated with the neo-classical paradigm was becoming an anachronism" (Deane 1978:175-176) the economicostructural changes in the early twentieth century led to a new economic doctrineKeynesianism. In turn, the new economic theory influenced policies and hence the economic structure. "Keynes's ideas gradually found their way into policy proposals of governments" (Breit and Ransom 1971:82).

Keynes was promoting state intervention that would raise the propensity to consume and the inducement to invest, as he saw both factors as necessary to achieve full employment and a just distribution of wealth. The question is, how far and when the governments adopted Keynes's policy prescriptions. This is the task of the following inquiry into British policy in the 20th century, beginning with the period between the two world wars, when policies in Keynes's sense were already partly applied. One event certainly had its impact on these policies-the further extension of the suffrage. 
The widespread extension of the franchise in 1918, which made virtually every man over twenty-one a voter and extended the ballot to many women over thirty, made unemployment and the related problem of the maintenance of the new wage scales matters of greater political importance than such things had been in the past. Unemployed voters could not be left to shift for themselves. (Dietz 1942:547)

In light of this, the government extended its intervention in the economy in order to relieve the trade recession and mass unemployment in the 1920s. The National Insurance Act of 1911, which introduced the unemployment insurance, was extended in 1920 "to cover all workers earning under $£ 250$ a year" (Dietz 1942:548). This new law insured about 12 million people. Other devices for handling the problem of unemployment in the 1920 s were grants to local authorities of 60 per cent of the wages bill on approved public works, and Exchequer loans for roads, sewers, parks, water, gas, and electric maintenance, and tramway undertakings (Dietz 1920:549). However, "public works were looked upon with disfavor as a more expensive and a more wasteful form of relief than direct maintenance" (Dietz 1942:549).

Moreover, the British government issued loans and credits to enhance trade and hence to increase employment (Dietz 1920:549-550). Three Housing Acts (1919, $1923,1924)$ led to a steady improvement of housing in the 1920 s and early 1930 s, when, encouraged and supported by governmental loans and subsidies almost 1.2 million new houses were built by local authorities and private enterprises (Dietz 1942:555557). Additionally, about the same number of units was built by private enterprises without financial assistance from the government, so that 
Great Britain, with over two million new houses, was far and away better off, from the point of view of the dwellings of people, than she had been at any time in her history. Much remained to be done before Englishmen lived in a decent house; but the back of one of the toughest British social problems had been broken. (Dietz 1942:557)

All the measures above either enlarged the propensity to consume or the inducement to invest, as Keynes would call it. So as early as the 1920 s and early 1930 s the British government did not follow neo-classical policy recommendations but pursued the policies that Keynes would recommend in the General Theory in $1936 .{ }^{48}$ However, this deviation from neo-classical theories was more a reaction to the pressure from the actual economic conditions than based on convictions. As mentioned, the public works program was not regarded as an appropriate cure for unemployment, and during and after the Great Depression the British government did not seem consistently to follow any theoretical considerations. "... the economy policies pursued ... in the course of the Great Depression were not influenced by consistent lines of theoretical consideration" (Pribram 1983:513).

Despite the common view among economists after the First World War that public works could reduce the unemployment rate, "the Treasury ... remained hostile to the idea of planned countercycle public works, with or without budgetary deficits",

\footnotetext{
48 However, Weir (1989:55) points out, that Keynes's influence on British politics was given already at this time: "... Keynes himself had urged a 'Keynesian-style' policy of deficit spending on public works even before he had worked out the theoretical apparatus in The General Theory. As co-author of the Liberal pamphlet Can Lloyd George Do It?, Keynes and like-minded members of the Liberal party laid out a clear alternative to economic orthodoxy during the 1929 election." Further, he published his view in the above mentioned essays and also got support from a majority of economists in regard to public works (see above). What distinguished Keynes's work before the publication of the General Theory is not a different perspective of the economy but the lack of an economic model that scientifically supports his views.
} 
whether the party in power were the Tories or Labour (Blaug 1968:655-656). The average expenditures of the first five years of the depression from 1929 to 1934 were the same as in the preceding years, the budget was always balanced (Dietz 1942:569). This also becomes clear when looking at the percentage of the GNP that accounted for government expenditures (Deane and Cole 1967:332-333). Throughout the 1920s the figures were around 8 or 9 per cent, and only from 1936 onwards there is an increase from 9.5 to 10.3 per cent, to 11.3 in 1937 , and 13.3 per cent in 1938 . According to Blaug $(1968: 656,663)$ by 1939 there was only one country-Sweden—that followed Keynes's policy recommendations of having unbalanced budgets to counterbalance the depression by a public works program.

Instead of employing people in public works programs, the British government prefered to "maintain" the unemployed, which was managed by adjusting the unemployment insurance to the depression years. An Act of 1934 on unemployment insurance "abolished nineteenth-century conceptions of poverty and defined various categories of assistance from short-term unemployment to long-term disabled and infirm" (Holmes 1976:201-202). Dietz reports that, although the unemployment benefits of the insurance were soon exhausted, unemployed workers and their families received repeated extensions and uncovenanted benefits. "Thus the unemployment insurance scheme ceased to be an insurance arrangement and became a system of relief supported by workers who still had jobs, employers whose factories still ran, and the state, with 
the deficits covered by loans" (Dietz 1942:570). Speaking in Keynes's terms, the government supported the consumption function.

However, government did little to induce investment or invest itself during the depression years: "... there was little new recourse of this method of providing men with work or of stimulating industrial activity by pump-priming" (Dietz 1942:571). Except for the promotion of "cheap money" via low interest rates, all measures to restore prosperity, such as the adoption of protective tariffs, guaranteed prices for agricultural products, and industrial and economic planning largely in cooperation with employers-"state intervention in Britain could hardly be imposed from above but rather was effective within the limits of employer's willingness to cooperate" (Holmes 1976:162) - were directed to retain production, secure incomes, and avoid inflation, rather than to induce investment. ${ }^{49}$

Despite the inconsistency in regard to economic theories, one tendency can be recognized when looking at economic policies in the 1930s - the disbelief in free trade and laissez-faire, and, hence, the decline of the neo-classical doctrine.

It was no longer fashionable to believe that buying in the cheapest, and selling in the dearest market would bring maximal social advantages. Laissez-faire might bring the greatest wealth to certain individuals, but it was now seen that the unrestrained operation of the forces of competition had the effect of exposing the masses of those who were less well endowed physically and mentally, or less well trained, or who lived on poorer soils, to the certainty of poverty and unemployment in times of strain. (Dietz 1942:567)

49 For a detailed discussion of the specific state interventions in agriculture and industry see Holmes (1976:146-164). Weir (1989:60-63) explains the rejection of deficit-financed public works as caused by the hierarchical character of the British bureaucracy and the dominant role of the Treasury. 
This trend was continued and accelerated during the Second World War. The intervention of the state in economic life had grown to an unprecedented degree during the war. The principal means of governmental war organization were to maintain low interest rates, deficit-spending, and direct quantitative controls over production, allocation of materials and labor, and consumption (Eatwell 1985:66-67). "World War II came and overnight removed the inhibitions that had limited government spending and the worries and suspicions it aroused in the minds of businessmen" (Heilbroner 1972[1953]:283). Hence, during the Second World War "a rapid acceptance of Keynesian budgetary principles broke with long-standing patterns of national economic policy and proved the first step toward the broad acceptance of Keynesian policy" (Weir 1989:54)..$^{50}$

There was a widespread sense that, unless governments were actively committed to preventing it, large-scale unemployment would once again characterize the decades after peace turned. The experience of successful state intervention during the war led to a different perception of the role the state should play in economic and social questions.

But if the state could sort out the problems of wartime planning, surely it could also plan the peace. The prestige of state intervention and the belief that it could be used to prevent the return of economic disasters in

\footnotetext{
50 After the outbreak of hostilities Keynes was directly involved in this opinion change as he "was given office in the Treasury from which to pursue the many aspects of wartime economic administration" (Weir 1989:55). Furthermore, the economic section of the war cabinet which consisted of several dedicated Keynesian economist "used its central position to keep issues of Keynesian economic policy on the national agenda throughout the war" (Weir 1989:66).
} 
peacetime were enormously encouraged by this experience. (Bleaney 1985:82)

People remembered that the end of the first World War had been accompanied by a very severe slump in the 1920 s and a whole decade of depression in the 1930s, and they were wondering and discussing how this could be avoided. The answers they found were a more state-directed economy and the establishment of a modern social security system. In December 1942 the Beveridge Report was published by the government, "a plan to establish social security for all from the cradle to the grave" (Bleaney 1985:81). The report rested upon three assumptions-that family allowances would be paid for all children, that a National Health service would be set up, and that full employment would be guaranteed by the state (Howlett 1994:27). Beveridge's report received widespread support- 86 per cent of the British people were in favor of its adoption, only 6 per cent were against it (Addison 1977:217). A series of legislation laid down the foundations of the British post-war welfare state by 1948 "which has remained fundamentally the same since that date": in 1944 the Education Act, in 1945 the Family Allowance Act, in 1948 the National Assistance and Children's Acts, and in 1949 the Housing Act (Johnson 1994:287). According to Johnson (1994:287), there were two broad types of benefits - directly provided services and cash transfers. The first, tax-financed group included public housing, public education, and national health service. The cash transfers were themselves of two types, some being provided through the contributory system of National Insurances (in cases of retirement, sick- 
ness, disability, and unemployment), and others (national assistance and family allowance) being paid on a non-contributory basis from general tax revenue.

As shown, Britain had established a public welfare system with many of the characteristics found in the post-1945 welfare state as soon as the eve of the First World War. However, most social expenditure before 1914 "was based on the concept of a residual welfare state, a system of physical and financial safety nets which prevented absolute destitution" (Johnson 1994:285). Pre-war welfare was pretty limited in scope, whereas by 1948

the welfare state was pretty different in size and character. It accounted for 10 per cent of GNP [before 1914 it was less than 6 per cent], and was more centralised and much more comprehensive in terms of the proportion of the population and the type of social contingencies covered. It had changed from being a residual to an institutional welfare system, integral to the structures of modern industrial society. (Johnson 1994:285)

In the four decades since 1948 government social expenditure rose from less than a third to over a half of total government expenditure and to 20 per cent of GNP. This steady rise was stopped only in 1974 when first cuts took place in expenditures for education, housing, and health benefits, and especially from the early 1980 s onwards, when deep cuts in the social security system decreased social state expenditures (Johnson 1994:298).

Given the post-war atmosphere that supported a welfare state, and the apparent failure of neo-classical economics to analyze the problems of the 1920s and 1930s, not 
only a welfare system was created, but also Keynesian monetary and fiscal policies were created in accordance with his recommendations after the war:

During the war its influence grew steadily in both academic and policymaking circles to the point where one could say that, in 1945, it had more or less established itself as the new orthodoxy. ... Keynesian economics was beginning to be conceived not just as an emergency weapon, which might be kept in the government's policy cupboard until a depression threatened, but as a tool for stabilisation of the economic system by continuous, even though possibly quite minor, adjustments of the budgetary stance. (Bleaney 1985:83)

Toward the end of the war, Keynesian ideas were fully established by the British Treasury and "were at the centre of discussions about the future conduct of macroeconomic policy in peacetime" (Bleaney 1985:84). A White Paper, published in 1944 and supported by all parties, declared: "The Government accepts as one of their primary aims and responsibilities the maintenance of a high and stable level of employment after the war" (Lekachman 1966:177). ${ }^{51}$ The Paper outlined the policies the government intended to pursue to achieve this ambitious goal: monetary policies as measure to influence investment expenditures via the level of interest rates, counter-cyclical expenditures of the public sector, including budget deficits, and manipulation of consumption via tax rates and social insurance contributions (Bleaney 1985:85). These were exactly the policy recommendations derived from Keynes's analysis of the econ-

\footnotetext{
51 Weir (1989:79-81) discusses why the Labour Party as well as the Conservative Party advocated full employment and demand management.
} 
omy which the British government fully embraced. ${ }^{52}$ From the end of the Second World War until the 1970s

the broad lines of budgetary policy, and indeed of monetary policy, had been formed on Keynesian lines. The role of the budget and of monetary policy was to ensure that the level of effective demand was appropriate to the full utilization of resources, with due regard for the rate of inflation and the foreign balance. (Eatwell 1985:69-70)

52 For a more detailed discussion of the policies after 1945 until the 1970s see Eatwell (1985:66-70), Cairncross (1994a, 1994b), and Tomlinson (1994). 


\section{Zwischenbetrachtung-Interim Reflection}

With Keynes's economic theory all possible views of the idea of general abundance are stated. The proceeding chapter covering the final period of economic thought does not develop the idea further, but merely revitalizes it by drawing upon the first three periods.

On the one hand, we have the economists that share the view that the economic development will lead to general (Smith, Keynes), or at least broad (Marshall), abundance. On the other hand, there is Ricardo who constitutes the only exception in orthodox theory in regard to the possibility and probability of general abundance. Based on his experience of tremendous population growth, and the ability of the landowners to keep their rents up due to the Corn Laws, he was very pessimistic about wealth for everybody. If this were possible at all it would only occur through strict laissez-faire that excluded any poor relief or welfare legislation, thought Ricardo.

The question of state intervention separated the classical, neo-classical and Keynesian school in regard to how they thought general abundance could come into existence. Classical and neo-classical scholars believed in a self-regulating free enterprise system and advocated laissez-faire. This belief was either based on philosophical deductions as in Smith's case, who saw a benevolent deity directing self-interest so as to promote the wealth of the nation, or on more scientifico-mathematical reasoning as exemplified by Alfred Marshall who used marginal utility analysis to prove his 
assumptions. Keynes revolutionized orthodox economics by mathematically showing that the self-regulating mechanisms usually do not work. So he abandoned laissez-faire and advocated state intervention in the economy.

The following developments in economic thought-Monetarism, New Classical Macroeconomics, and New Keynesianism-integrate more elements in their theories, for example rational expectations, but their prospect of general abundance is not influenced by these changes. The new schools merely repeat the views of their predecessors. Monetarism and New Classical Macroeconomics advocate laissez-faire, New Keynesianism promotes state intervention in the economy. What did change, however, was, as already seen with Marshall, that there is no longer talk about general abundance. What the economists since the late 1960s are looking for are the best conditions for the economy to grow, or at least, to maintain its desired level of output. It is implied that this will serve not only the economy, but the wealth of the people. However, there are no promises of general, not even broad abundance any more. If notions in this respect can be found, they simply deal with the question of full employment. Keynes's notion of a redistribution of wealth is not of importance for economists any more. 
5. Monetarism, New Classical Economics, and New Keynesianism (mid-1960s until today)

\subsection{Much Ado about Old Ideas}

Until the mid-1970s Keynesianism was the orthodox economic theory.

Keynes's followers adapted his teachings to current phenomena and methodological developments, without abandoning the principles of Keynesian macroeconomic theory. 53

A Keynesian school formed itself, ... a genuine one which is a sociological entity, namely, a group that professes allegiance to one master and one doctrine, and has its inner circle, its propagandist, its watchwords, its esoteric and its popular doctrine. Nor is this all. Beyond the pale of orthodox Keynesianism there is a broad fringe of sympathizers, and beyond this again are the many who have absorbed, in one form or another, readily or grudgingly, some of the spirit or some individual items of Keynesian analysis. (Harris 1948:97)

One of the changes the school undertook was to incorporate the "Phillips curve" into Keynes's theory. While Keynes himself had little to say about inflation, Keynesian economists integrated this curve that shows an inverse empirical relationship between inflation and unemployment into their analysis. "The 'Phillips curve" was

53 For overviews of the development of Keynesian economics see Pribram (1983:503-515) and Deane (1978:185-189). 
taken to indicate that unemployment could be lowered simply by allowing a somewhat higher rate of inflation" (Hoover 1988:4).

However, from the mid-1960s onwards Keynesianism began to fall out of fashion in academia. After decades of unchallenged dominance a powerful theoretical counterrevolution occurred.

In the mid-1960s the theoretical Keynesian revolution began sputtering and by the mid-1970s it came to a complete halt; Keynesians under thirty-five became the endangered species; only those economists over fifty remained Keynesians and many went into the closet. (Colander 1988:92)

Economists resurrected pre-Keynesian economic theories, namely classical and neo-classical notions of how to analyze the economy. ${ }^{54}$ The "counterrevolution ... reinstated the pre-Keynesian orthodoxy in a modern guise" (Dow 1988:101). The first theoretical movement against Keynesian economics acquired the name "Monetarism" and was "associated to a quite exceptional degree (...) with the thinking of one man, Milton Friedman" (Bleaney 1985:132) ${ }^{55}$ Friedman regarded the quantity of money as the key element influencing effective demand, whereas he regarded the Keynesian

\footnotetext{
54 Hoover (1988:3-6) argues that the Keynesian dominance in economics ended because of two reasons: first, there was a desire to integrate micro-foundations for aggregate economic relationships in economic theory, second, in the early 1970s, both the rate of inflation and the rate of unemployment rose dramatically (known as stagflation), which was not possible in Keynesian terms. Hence, both new schools (monetarism and new classical) are examples that show the influence of the economic structure on economic theory. However, the initial theorizing in this direction began in the mid-1960s when the economy was still booming. Therefore, it seems that dissatisfaction with Keynes's theory was the primary force for the development of the new schools, especially in the case of monetarism. Their acceptance as new orthodoxy, however, was surely enhanced in light of the economic situation in the 1970s.

55 Laider (1981) summarizes the positions taken by monetarists.
} 
measures of low interest rates and fiscal policies as ineffective. He concluded that "time lags in the effect of policy measures are fairly long and variable, so that it is difficult for the authorities to exert any consistent stabilising influence on the natural fluctuations of the private sector" (Bleaney 1985:141). Therefore, monetarists recommended as a leading policy principle to pursue a "target rate of growth of the stock of money ... irrespective of the current state of the economy" (Bleaney 1985:139). Any other state interventions were seen as not necessary, as Friedman believed in self-stabilising tendencies inherent in a free enterprise economy. "We are back in a completely neoclassical world, where it is assumed that if the real wage is such as to equalise the demand and supply of labour, full employment follows automatically" (Bleaney 1985:140).

In the 1970s monetarism was theoretically exhausted, but another school, known as "New Classical Economics" or "New Classical Macroeconomics," took over to further demolish Keynesian thought, based "on the groundwork that has been done by Friedman" (Bleaney 1985:142). Its main proponents were Robert Barro, Robert Lucas, Thomas Sargent, and Neil Wallace. The new classical school became the mainstream economic view in the early 1980s (Colander 1988:92-93). Its analysis blended assumptions of rational expectations and market-clearing within a general equilibrium framework. The essential novelty was the treatment of expectations. "Rational Expectations assumes that economic agents are completely aware of the true structure of the economy $(\ldots)$ and make full use of this knowledge in forming their 
expectations" (Bleaney 1985:143). By introducing the expectations assumption new classicists turned their attention to a more individualistic level of economic behavior and so repeated a neo-classical pattern by "denying that economics can say anything about unemployment at the macrolevel, i.e. by defining the problem away" (Dow 1988:107). The market clearing assumption resurrected Say's Law of markets (see 4.2). It postulated that "prices are sufficiently flexible to clear all markets in each time period. Whatever is produced is sold, though of course maybe not at a price which satisfies the producers" (Bleaney 1985:146). The general equilibrium came in as an aggregate supply curve which assumed that the economy naturally tended toward stability, i.e. full employment (Bleaney 1985:146-148). With these three assumptions new classical economists were able to "show that any systematic government policy is ineffective" (Bleaney 1985:151). ${ }^{56}$

Monetarism and new classical economics have in common their underlying motivation - to revolt against Keynesianism-, their renewed advocacy of the free market, and in turn their antipathy to almost all forms of state intervention in the economy. ${ }^{57}$ What distinguishes the two schools from notions of classical and neo-classical

\footnotetext{
56 Bleaney (1985:154) points out that neither the monetarist nor the new classical school proved its policy recommendations: "No attempt has been made by Monetarists or New Classicists to justify their summary rejection of Keynes's theoretical arguments; they simply choose to dismiss them by assumption."

57 In fact, new classical economics was hardly concerned with practical issues, it was a "theoretical revolution. To the degree that it was concerned with practice, it simply borrowed monetarist policy prescriptions" (Colander 1988:99).
} 
economics is not a far-reaching development of Ricardian and Marshallian ideas, but rather a different methodology, namely the application of econometrics..$^{58}$

The same principle is true for the third development in economic theory since the 1970s-the evolution of Keynesian economics to "New Keynesian Economics" which was provoked by the new classicists's success. The new Keynesians-among the leading economists are John Taylor, Joseph Stiglity, George Akerlof, Meir Kohn, and Peter Howitt—embraced old (Keynesian) ideas but applied more advanced, econometric methods to prove their views. This most recent development occurred in the mid1980s. What the theorists of this school did, was essentially to "develop alternative Keynesian models, written in the style of New Classical models and including rational expectations, but which came to Keynesian conclusions" (Colander 1988:97). New Keynesians followed Keynes's tradition of attributing to the government certain roles in regulating the economy.

New Keynesian theory uses the same formal general equilibrium methodological framework as New Classical theory uses, but it does not use the market clearing assumption. A New Keynesian article looks similar in form to a New Classical article, but because it does not assume market clearing, the conclusion New Keynesians come to is that there is a potential role for government policy. ... individual decisions do not lead to socially optimal results. (Colander 1988:93)

58 Pribram (1983:513-515) discusses the post-war "trend to give advanced mathematical methods exclusive predominance" in economics, which finally gave way to the transformation of what was once called "Political Economy" into "Econometrics"-a science of applied mathematics. 
With this last theoretical turn economics became divided between two competing blocs that try to arise as the mainstream theory of their profession. ${ }^{59}$ Hoover (1988:12) points out that the differences between new classicists and new Keynesians "revolve around empirical questions rather than matters of theoretical principle. ... The remaining theoretical differences between them are principally questions about how self-correcting the economic system is." In light of the new "Beliebigkeit" or wide variety of policy-recommendations, politicians have the postmodern choice between "anything goes" or "rien ne va plus." What Peden (1985:223) already sees happening in the 1970s-"the growing split in the economics profession in the 1970s made it possible for politicians to choose whichever economic advice suited them"-accelerated in the 1980 s and 1990 s.

\subsection{The Comeback of Laissez-Faire}

As shown above, the experience of the Great Depression influenced perceptions of the state and the role it ought to play in the post-war period. "Live memory of the Great Depression created a broad consensus that the state must assume responsibility for maintaining prosperity, as well as for protecting individual citizens against the inevitable insecurities of life in a market economy" (Tobin 1987:89-90). The British governments of various political color reacted by embracing Keynesian economics.

59 Colander (1988:98) sees a great chance that new Keynesianism will make a comeback as orthodx economics, however, "the current state of Keynesian macroeconomics is one of confusion." 
Since the end of the Second World War the broad lines of British fiscal and monetary policy had been formed on Keynesian lines. The role of these policies was to ensure that the level of effective demand was appropriate to the full utilization of resources, with due regard to the rate of inflation and the foreign balance. Furthermore, the social welfare system was expanded. The existence of the welfare state "was commonly regarded as the test of a caring, civilised society" (Bleaney 1985:185). Until the early 1970s the new policies seemed to work well. The post-war period until 1973 was one of unparalleled prosperity, growth, expansion of world trade, and stability. The business cycle was tamed. "Under the continuing impetus of public and private spending, all capitalist nations began to evidence steady growth" (Heilbroner 1972[1953]:286). The British economy had growth rates of 2.6 per cent from $1950-60$, and 2.8 per cent from 1960-70 (Eatwell 1985: 63). Unemployment was low-from 1950-60 the average unemployment rate was 2.5 per cent, from 1962 to 19733.1 per cent (Bleaney 1985:94). Consumer prices were pretty stable until the early 1970s (Cairncross 1994a:51, Cairncross 1994b:62).

The embracement of Keynes's policy recommendations ended in 1976. James Callaghan, the Labour Prime Minister, told his party at a national meeting in September that the Keynesian option of spending one's way out of a recession had failed:

We used to think that you could just spend your way out of a recession and increase employment by cutting taxes and boosting government spending. I tell you in all candour, that option no longer exists, and that in so far as it ever did exist, it worked by injecting inflation into the economy. And each time that happened the average level of unemploy- 
ment has risen. Higher inflation followed by higher unemployment. That is the history of the last 20 years. (Callaghan as quoted in Peden 1985:221)

From 1976 and especially from 1979 onwards, when the Conservative Party with Margaret Thatcher as new Prime Minister gained power, the mechanisms of Keynesian economic theory were decisively abandoned in favor of monetary probity. In the 1970s the "key element in British economic policy has been a desire to reduce intervention by the state" (Eatwell 1985:65). The governmental withdrawal from active economic as well as social policies in Britain

... manifests a conservative counter-revolution in the theory, ideology, and practice of economic policy. The aim of the counter-revolution is to shrink the economic influence of government, especially central government, relative to that of private enterprise and free markets. (Tobin 1987:89)

The background of the abandonment of Keynesian policy recommendations and the embracement of monetarism and later new classical economics is the economic development of the 1970s. "The disappointments of the 1970s-inflation, stagflation, recessions and unemployment resulting from anti-inflationary politicies-discredited Keynesian policies" (Tobin 1987:5).

What had happened? The long-lasting post-war boom had broken down. "The year 1973 marked the end of the 'golden age' of sustained economic growth, full employment and reasonable stable prices" (Peden 1985: 206). This was symbolised by 
the "energy crisis" and world-wide recession which followed a decision of the Organization of Petroleum Exporting Countries (OPEC) to massively increase (four-fold) the prices for oil in 1973.60 "Since that date, the economic performance of the advanced capitalist countries has clearly deteriorated. Growth rates have fallen. The rate of unemployment has increased and stayed high" (Bleaney 1985:155). Again in 1979 the OPEC increased the oil prices $2 \frac{1 / 4}{4}$ times and initiated a second worldwide economic crisis.

A few data, given by Johnson (1991:265, 315) and Peden (1985:206-208) show clearly the extent of the depression Britain went through in the 1970s (see Table 1). Following the oil crisis, the gross domestic product (GDP) fell in 1974 by 1.5 per cent for the first time since 1946 and by 0.8 per cent in 1975; the level of output was not exceeded until 1977. Between 1980 and 1981 it fell again ( 2 and 1.2 per cent), and the 1979 level of output was not reached until 1983. The unemployment rates constantly rose from 2.6 per cent in 1973, reached the two-digit number with 10.5 per cent in 1981, and continued rising until they reached a peak of 13.1 per cent in 1985. In 1988 they dropped below 10 per cent for the first time since seven years. The rate of inflation dramatically increased to a peak of 24.1 per cent increase in 1975 and stayed in the two-digit range until 1982, except for 1978 when it dropped to 8.2 per cent.

60 For an overview of the oil crisis and its effects see Issawi (1978). 
Table 1. The Recessions of $1974 / 75$ and 1979-81 in Great Britain

\begin{tabular}{|l|l|l|l|}
\hline Year & $\begin{array}{l}\text { Unemploy- } \\
\text { ment } \\
\text { (annual average } \\
\text { in per cent) }\end{array}$ & $\begin{array}{l}\text { Inflation } \\
\text { (percentage } \\
\text { increase in } \\
\text { retail price } \\
\text { index) }\end{array}$ & $\begin{array}{l}\text { Economic } \\
\text { Growth } \\
\text { (percentage } \\
\text { changes in } \\
\text { GDP) }\end{array}$ \\
\hline 1973 & 2.6 & 9.1 & 2.4 \\
\hline 1974 & 2.6 & 15.9 & -1.5 \\
\hline 1975 & 4.0 & 24.1 & -0.8 \\
\hline 1976 & 5.4 & 16.6 & 2.6 \\
\hline 1977 & 5.8 & 15.9 & 2.6 \\
\hline 1978 & 5.8 & 8.2 & 2.9 \\
\hline 1979 & 5.4 & 13.4 & 2.8 \\
\hline 1980 & 6.8 & 18.0 & -2.0 \\
\hline 1981 & 10.5 & 11.9 & -1.2 \\
\hline 1982 & 12.0 & 8.6 & 1.7 \\
\hline 1983 & 12.4 & 4.5 & 3.8 \\
\hline 1984 & 12.6 & 5.0 & 1.8 \\
\hline 1985 & 13.1 & 6.0 & 3.8 \\
\hline 1986 & 11.5 & 3.4 & 3.6 \\
\hline 1987 & 10.3 & 4.2 & 4.4 \\
\hline 1988 & 8.1 & 4.9 & 4.7 \\
\hline 5045 & 561901 & \\
\hline
\end{tabular}

Source: Johnson (1991:265, 280, 315)

Besides the breakdown of the post-war boom one has to recognize another fact that might have contributed to the abandoning of Keynesianism. By 1948 Britain had established a modern welfare system that increasingly used public social expenditure to change and improve society, or, in other words, to fulfill the capitalist metanarrative's promise of wealth for everybody. The question is, if the welfare state succeeded in distributing wealth more equally or, at least, in reducing poverty. Neither seems to be the case. 
Data given by Johnson (1994:303), measuring the distribution of personal income from 1949 to 1976 (see Table 2) show that the income tax system consistently worked to reduce the share of after-tax income received by the top 1 per cent of earners and also the group that earns 2 to 10 per cent of the national personal income. Indeed, a redistribution of income took place during this period, however, "nearly all this equalisation occurred within the top half of the distribution, with transfers over time going from the top 10 per cent (and especially the top 1 per cent) of income units to those in the next 40 per cent" (Johnson 1994:304). Despite gains the income of the poorest half of the distribution accounts for less than $1 / 3$ of the income share throughout the post-war period.

Table 2. Distribution of personal income, 1949-1976/77

(in per cent)

\begin{tabular}{|l|c|c|c|c|}
\hline Income group & $\mathbf{1 9 4 9}$ & $\mathbf{1 9 5 9}$ & $\mathbf{1 9 6 7}$ & $\mathbf{1 9 7 6 / 7 7}$ \\
\hline before income tox & & & & \\
top 1 per cent & 11.2 & $\mathbf{8 . 4}$ & 7.4 & 5.6 \\
2-10 per cent & 22.0 & 21.0 & 20.6 & 20.4 \\
11-20 per cent & 14.1 & 15.1 & 15.2 & 16.1 \\
21-30 per cent & 11.2 & 12.6 & 12.6 & 13.3 \\
31-40 per cent & 9.6 & 10.7 & 11.1 & 11.1 \\
41-50 per cent & 8.2 & 9.1 & 9.1 & 9.2 \\
51-100 per cent & 23.7 & 23.1 & 24.1 & 24.5 \\
\hline after income tax & & & & \\
top 1 per cent & 6.4 & 5.3 & 4.9 & 3.5 \\
2-10 per cent & 20.7 & 19.9 & 19.4 & 18.9 \\
11-20 per cent & 14.5 & 15.7 & 15.2 & 15.9 \\
21-30 per cent & 11.9 & 12.9 & 13.0 & 13.4 \\
$31-40$ per cent & 10.5 & 11.2 & 11.0 & 11.3 \\
41-50 per cent & 9.5 & 9.9 & 9.7 & 9.4 \\
51-100 per cent & 26.5 & 25.0 & 26.8 & 27.6 \\
\hline
\end{tabular}

Source: Johnson (1994:303) 
Furthermore, according to Johnson (1994:301) poverty could not be abolished

during this period either:

In the mid-1960s social researchers discovered widespread poverty in many families with dependent children and among pensioner households, two groups who were specifically supported by the welfare state through the payment of family allowances and old age pensions (...). Subsequent studies (...) found that poverty continued to be a major problem throughout the 1960s and 1970s, despite the rapid growth of social expenditure, and a survey of evidence in 1987 concluded that the burden of poverty has increased grotesquely over the last eight years' (...). The number of means-tested benefits because of poverty doubled from 1 to 2 million between 1948 and 1966, and doubled again to reach over 4 million in the deep recession of the early 1980s, with many more living on incomes only marginally above this poverty threshold. ... in 1983, 16.3 million people in the UK lived in households on or just above the poverty line-almost one in three of the population. ${ }^{61}$

That means that despite the overall rise in average income and the great growth of social expenditures poverty was a major problem throughout the post-war decades in Britain. There might have occurred some improvements in the 1990s due to an economic boom (see below), but the overall situation has not been changed. In regard to the promise of general abundance, therefore, it can clearly be stated that this was not fulfilled. "The enormous growth of social expenditure since the Second World War does not appear to have reduced relative poverty or promoted greater income equality" (Johnson 1994:305). Moreover, in light of the Keynesian-led governmental efforts,

61 These data are based on relative poverty measures, i.e., they are related to average living standards and hence lead to the situation that "in a wealthy society people can be considered poor long before they are destitute" (Johnson 1994:301). This kind of definition of poverty is justified because a full participation in the average style of living requires resources that are not necessary to survive, however, necessary in order to be acknowleged as a member of society. 
especially in the 1960s and 1970s, which permitted an optimistic outlook on the possibility of broad welfare, and the apparent failure to significantly reduce poverty, it can be stated that a decline of the metanarrative in the economic structure is occurred.

There are many reasons for the breakdown of the post-war boom in the 1970s-fundamental changes in international economic relations, errors of macroeconomic policies, supply-side contraints, inflationary expectations, distribution conflicts, the growth of the public sector, and commodity price increases, especially of oil prices. ${ }^{62}$ However, according to Bleaney (1985) only a few factors-rising aspirations, followed by a distributional conflict, combined with the rise in commodity prices-were of crucial importance.

The historical experience of the depression and the two world wars depressed popular aspirations and kept distributional conflicts pretty low. ${ }^{63}$ This changed in the last quarter of the 20th century. Political stability, a buoyant labor market, and rising living standards in the 1950s and 1960s meant a great improvement for society. "The insecurity which had been a characteristic of working-class experience in earlier phases of capitalism largely disappeared" (Bleaney 1985:201). The sense of security of employment combined with the prospect of a steady rise of real wages was a novelty for Britain and the European countries overall. High rates of investment brought forth high productivity rates, while strong demand conditions held profits up, and in turn the

\footnotetext{
62 For a detailed discussion of the causes of the recessions in the 1970s see Bleaney (1987:157-196).

63 There is a term--"post-war settlement"-that symbolizes a consensus between trade unions, industry, and the governments in the post-war period until the early 1970s. In simple terms the basis of this consensus was the willingness of the trade unions to restrain real wage growth in exchange for a full employment pledge by the government. (Broadberry 1994:211-214)
} 
high rates of investment as well. In fact, because productivity growth was so fast, real wages rose at rates which had not been matched in any sustained period of previous history

Popular aspirations have risen with the apparent stability of the new regime of full employment, prosperity and growth and the fading from memory of the earlier era of insecurity. People have come to expect that work will be readily available for those who are seriously looking for it, and that economic development will make their lives steadily easier and materially better. In the 1960s expectations adapted to the historical realities of the post-war period. The route of growth of real wages set up in the 1950s, and then historically unprecedented ... came to be built into people's aspirations. (Bleaney 1985:183)

The very solidity and stability of the post-war environment encouraged people to take its achievements for granted, and this accelerated the process of rising aspirations. Popular perceptions of social wealth and private expectations began to catch up with what the economic system could easily offer.

The expectations of full employment and general abundance increasingly came into conflict with the stability of prices and the maintenance of social consensus from the 1960s onwards. "In the 1960s these expectations, based on the spectacular growth of the 1950s, began to come into conflict with what the economic system could deliver without significant distributional shifts" (Bleaney 1985:202). As result of the higher expectations and increased state expenditures through higher taxation for the social welfare state, a wage-price-spiral was set in motion. Workers and unions fought for steadily increasing real wages and this led to an upward pressure in production costs. 
This in turn has been met by employers by raising prices for commodities. Finally, this was followed by a tremendous inflation, which accelerated after a commodity price boom in 1972 and 1973. The final consequences of these developments were deep recessions in 1974-75 and in 1979 to 1982.

In order to deal with the severe slump of 1974-75 the Labour government, in power since February 1974, reacted in the way prescribed by Keynes-it increased public expenditures, financed by loans. In 1975 the rate of public expenditure increased 40.4 per cent, in 197645.5 per cent (Peden 1985:218) ${ }^{64}$ The money was spent for improved welfare benefits, subsidies intended to hold down the prices, increased support for industry, funding for industrial innovation, and increased local subsidies (Peden $1985: 216,218)$. However, the problems of inflation and unemployment could not be solved-unemployment rates continued to increase, inflation was still at about 16 per cent. In addition, the Pound sterling rapidly declined in 1976 from an exchange rate of $\$ 2$ at the beginning of the year to $\$ 1.56$ in October (Peden 1985:219). This sharp decline raised import costs and made the inflation even harder to control. Subsequently the sterling crisis forced the government to abandon its costly Keynesian policies:

Even if most Labour ministers held to Keynesian doctrines of stimulating demand by loan-financed public expenditure, their room for manoeuvre was limited by the need to sustain confidence in sterling in a world which was coming increasingly to believe in monetarist doctrines. ... The Labour government had to announce monetary targets acceptable to those from whom it wished to borrow, and for that reason had to eschew reflation. (Peden 1985:221)

64 Bleaney (1985:210) points out that the worldwide embracement of Keynesian policies as first reaction to the oil crisis "prevented a repetition of the 1930s collapse." 
The sterling crisis of 1976 marked the end of Keynesian economic policies in Britain. The government introduced targets for monetary aggregate growth (12 per cent in 1977), and targets for credit expansion ( $£ 9$ billion in 1977, $£ 7.7$ billion in 1978, £6 billion in 1979) (Peden 1985:219). It met these targets by cutting expenditures and increasing national insurance contributions. Despite efforts which were made "to help the poorest members of society", for example by excluding social security from major cuts and the creation of job programs for young people, the growth of the British welfare state ended in 1976 (Peden 1985: 216-217, 220-221).

With the gain of power by the Conservative Party in 1979 this withdrawal from Keynesian economic policies was reinforced and settled the matter until today. Whereas Labour embraced monetarist econonomic policies out of external pressures, and still was convinced of Keynesianism, "Thatcherism" dropped Keynes like a hot potato.

If 1976 marked the end of the 'Keynesian' era, the election of the Conservatives under Margaret Thatcher in the general election of 1979 saw the beginning of a determined attempt to reverse the trend towards greater state intervention in the economy. ... The priority given to counterinflation policy over employment policy had begun under Callaghan; the difference under Thatcher was that Keynesian reflation was echewed indefinitely, and not merely until such time as the balance of payments and foreign confidence in sterling had improved. (Peden 1985:222-223)

The Conservative Party "had avoided any commitment to full employment in 1979, the first government to do so since the war" (Peden 1985:228). Thatcher's eco- 
nomic policy aimed at stimulating growth and bringing the rates of inflation down, not at full employment. The policies created to meet these aims were all directed by the conviction that the free market instead of government intervention will do the best job in bringing prosperity back to the island. In practice this meant that demand-side policies were abandoned in favor of supply-side policies. "Margaret Thatcher has put her countrymen and women on notice that the only way they can restore the jobs and prosperity lost in the current slump is to disinflate. Her Majesty's Government will do nothing about it except for "providing a stable monetary and fiscal framework within which private enterprise and free markets will restore prosperity and non-inflationary growth" (Tobin 1987:94).

Monetary growth was limited to fight inflation. ${ }^{65}$ State expenditures and state borrowing were reduced; the latter to balance the budget. "At the level of free-market ideology Mrs Thatcher ... saw the public sector as an enemy country to be conquered, deprived of much of its territory and put under the yoke of the Treasury" (Johnson 1991:76). This emphasis led to reduced subsidies for industry and the regions, the sale of state enterprises, and cuts in social security benefits, local-housing programs, and educational programs. ${ }^{66}$

Tax cuts for enterprises and individuals were introduced that were intended to encourage investment (Peden 1985:226-227). In June 1979 the top rate of income tax was cut from 83 per cent to 60 per cent as well as the standard rate from 33 to 30 per

65 For a detailed discussion of monetary policies since 1979 see Johnson (1991:27-75).

66 For a detailed discussion of budgetary measures since 1979 see Johnson (1991:76-106). 
cent. At the same time the value added tax was raised from 8 to 15 per cent, putting overall more tax strain on lower incomes: "... only people who had been paying top tax rates in 1979 had benefited substantially from tax cuts" (Peden 1985:227).

The problems of this supply-side approach are stated by Tobin:

Fed money supply policies will not allow for real economic growth unless wage and price inflation melts by a point or two a year. Given the stubbornness of built-in wage and cost inflation, there is likely to be considerable economic pain and damage during a transition of several years. ... In their absence [of wage and price policies], the only mechanism by which monetary deceleration produces disinflation is by creating sufficient economic distress that workers and employers, desperate to protect jobs and solvency, settle for lower wage and price increases than those currently prevailing. (Tobin 1987:95-96)

This is exactly what happened in Great Britain-the economy recovered gradually, the inflation rates were only declining slowly, the unemployment rates were at two-digit numbers until 1987 (see Table 1). So why did the government react that way? The answer is that the high inflation rates could not be accepted for they would endanger the political and social stability of the country.

The purely economic disadvantages of inflation for capitalist development do not seem great. The political effects are, however, potentially very damaging. Inflation creates an enormous degree of insecurity. In between pay settlements, wage and salary earners experience a continuous fall in their living standards with no guarantee that their next pay increase will be sufficient to compensate. Everyone feels that they have to run very fast in order to stand still; if they stop they will suddenly find their living standards cut by 10 or 20 per cent. Inflation is therefore experienced as very threatening, and liable to create quite arbitrary and sudden changes in income distribution. (Bleaney 1985:187) 
The long-term result of the above described economic and social policies which were pursued under Margaret Thatcher and John Major, the new conservative Prime Minister after Thatcher resigned in 1990, was indeed the recovery of the economy, but at the expense of the lower third of society. Since 1979 "income for the poor has been flat or fallen, while income for the rich has soared 62 percent" (Ibrahim 1997:C4). The British economy has been growing steadily since the mid-1980s, with a $2.6 \%$ gain in GDP in 1996, low inflation of about 2 to 3 per cent, and an unemployment rate of 6.1 per cent in March 1997 (Ibrahim 1997) ${ }^{67}$ However, despite the new prosperity, Britain currently faces growing problems of poverty, unemployment, and social exclusion.

For while the national averages portray a booming economy best seen in London, they obscure two other worlds within Britain where the pace of change has varied widely. There is the world of shuttered factories, chronic unemployment and unsolved welfare problems. And there is the world of slow but steady adjustment to new jobs that pay less. (Ibrahim 1997:A1).

In May 1997 the Labour Party regained political power after sitting on the opposition banks for 18 years. This political change, however, does not indicate significant policy changes. Tony Blair, the leader of the party since 1994 and new Prime Minister, promised in the election campaign not to raise personal income taxes for the next five years and not to exceed the current spending limits for two years (Hoge

\footnotetext{
67 A recent study by the Sheffield Hallam University Center for Regional Economic and Social Research shows that "Britain's unemployment statistics vastly understate the scope of the problem by leaving out people who claim benefits under a category known as 'permanently sick"' (Hoge 1997a:A6). According to the study the unemployment rate is actually about double the amount than claimed by the governmental statistics.
} 
1997a). "Under Mr. Blair, 43, the Labor Party has been profoundly transformed, abandoning its trade union, statist past and becoming a champion of entrepreneurship and individual enterprise" (Hoge 1997c:A6). There is no return to Keynesian policies in sight, except that "New Labour," the term Blair uses to call his party, promises "a kinder, gentler approach to the down-and-out", for example by reinstating a minimum wage and the adoption of a series of modest worker and job protection measures (Ibrahim 1997:C4). Overall, the free-market principles introduced by the Conservative Party from 1979 onwards will probably not be reversed. 


\section{Conclusion}

This last chapter is intended to briefly summarize the findings of this thesis, and to bring them back to Lyotard's statement that the capitalist, and metanarratives in general, are in decline. First, however, I would like to discuss the indications of this thesis for further research, and the applicability of the findings.

Within this thesis, I restricted the inquiry regarding the relationship between semantics and structure of the capitalist metanarrative to three complexes-the development of the idea of general abundance within economic theory, the policies in regard to this idea, and the economic structure. In some cases I went beyond this limited scope. For example, I looked at how pressures within the political and social structure related to the extension of suffrage, trade unions, the Labour Party, socialist ideas, and the international environment affected the political sphere and politicians' willingness to intervene in the economy. These few instances imply the complexity of the relationship between the idea of general abundance and the social base in which it is produced and received.

There are two areas at which, I think, would be important to look to further examine Lyotard's thesis of the decline of the capitalist metanarrative. First, the perception of and the belief in the promise of wealth for everybody in public opinion would be a further structural component that could support the findings of this thesis. How much did the public ever believe in the promise of wealth for everybody? Is the 
decline of the idea recognizable? Second, and related to the first area, it would be interesting to investigate what role politicians and parties played in actually promising general abundance. This would examine the semantics of the capitalist metanarrative further. For instance, an inquiry into party programs, election campaigns, and speeches of politicians could reveal answers to this question. Also, it would be worthwhile to look more closely at the actual economic theories now current. In this thesis I gave only a brief overview of the theoretical developments in the 1970s.

Overall, in regard to the long period of time that I attempted to cover, the inquiries concerning economic and political development, and the economic theories, could not be very deep. I intentionally abandoned depth in order to cover the long run of the general development of the capitalist metanarrative. Therefore, much further, more detailed research can be done. Also, it would be interesting to compare the political and social developments of Great Britain with those of other capitalist countries. Despite very different developments in other countries in this regard, I assume that my findings are broadly applicable, especially for the time after the second World War. However, I cannot prove this and an investigation of the economic development and the policies in, for example, the United State, France, Japan, and Germany could reveal interesting similarities and differences.

Now, let us come back to the findings. The idea of general abundance emerged in classical political economic thought as justification for the reinterpretation of acquisitive behavior. Adam Smith, the first economist to state the idea, was part of a 
group of social thinkers that helped de-moralize acquisitiveness. Pre-capitalist, traditional societies regarded striving for gain and money as a harmful and disruptive passion. However, a positive stance toward making money and amassing wealth in form of capital is the prerequisite of a capitalist society. In light of an already changing economic, political, religious, and social structure, a broad range of European philosophers argued that acquisitive behavior has a calming influence and civilizing effects on society. People pursuing their economic self-interest were believed to promote the welfare of the whole society, and, hence, to alleviate other disruptive passions, such as ambition, power, pleasure, and sex. So acquisitiveness gained the status of a harmonious interest.

The political economists of the classical period were strongly influenced by the development of the natural sciences of their time. Accordingly, they aimed at describing the economy in terms of natural laws, which, if followed by society, would lead to the most desirable ends, namely economic growth and material progress. Except for some tasks that they ascribed to the state, they envisioned a government that would not intervene in the economic order-a state of laissez-faire. The outstanding and most influential classical theorists were Adam Smith and David Ricardo. Smith, who is regarded as the founder of political economy, perfectly represented the optimism of the late 18 th century. He saw society as a sublime machine, created by a benevolent deity so as to maximize everybody's wealth. This benevolent power, often called "invisible hand" by Smith, endowed people with three moral sentiments-justice, prudence, and 
benevolence-that would lead their behavior to better their own and society's condition. Smith analyzed in the Wealth of Nations (1776) numerous flaws in this harmonious natural order. He blamed the incompetent, corrupt, mercantilist state, which he believed caused these flaws by intervening in the economy, for the deviations of the natural order. Consequently, he wanted the state to withdraw from almost all activities, except for three-the defense of the country, judicial administration, and some public works and institutions which he thought individuals could not erect and maintain, such as highways, bridges, harbors, postal service, and public education.

Smith was writing just before the economic take-off in the 1780s. David Ricardo, writing three decades after Smith, experienced a time of rapid transformations. In the first decades of the 19th century the Industrial Revolution was at its height with unprecedented growth rates of output, prices, incomes, and population. Social and economic distress were normal for the vast majority of people. The emergence of the bourgeoisie as an economic power was followed by a struggle for a political say, which, so far, the landed gentry inhibited. Ricardo's work reflects these changes. In particular, two political issues of his time are visible his Principles, published in 1817: the Corn Law dispute and population growth. Also the introduction and fight over the Speenhamland system is reflected in his theory. Ricardo, therefore, is the only theorist besides Keynes for whom it was possible to show a direct relation between the economic structure and the idea of general abundance. 
Ricardo's aim was to develop a law to regulate the distribution of income among landowners, capitalists, and workers. Integrating Malthus's principle of population, he drew a very pessimistic picture of the future of society. In contrast to Smith, he did not predict general abundance, but the emergence of a stationary state where economic growth would be eaten up by an ever-expanding population. The only remedy he saw for this was abandoning any kind of state intervention in the economy, including poor relief.

Despite the classical economists' advocacy of laissez-faire, the British government extended its power in the 19th century. It is true that many restrictions and regulations were swept away, but they were replaced by new ones which were more efficient and which the state actually could enforce. In particular, in regard to the condition of the working class and the poor, the government did not follow the classical economists' policy recommendations. The passing of a liberal Poor Law in 1796, and numerous legislation in the first decades of the 19th century, aimed at improving working and housing conditions, showed that the government obviously deviated from Smith's and Ricardo's policy bias.

The same pattern can be shown for the neo-classical school of economics that emerged in the last decades of the 19th century. It drew upon a method that was discovered during the marginal revolution by Jevons, Menger, and Walras in the 1870 s. Marginal utility analysis mathematically analyzed the economy. Using this analytical tool changed not only the methodology but also the scope of economic theory. The 
major concern of neo-classical economics, established as new orthodox theory from the 1890s onward, was how to get an optimal result by allocating scarce resources among competing uses. Neo-classical economists studied market processes and withdrew themselves from political questions of welfare and income distribution, claiming to practice ethically neutral science. However, their statements were still ideologically biased. Neo-classical economics implicitly supported the political status quo by claiming that perfect competition will lead to an equimarginal allocation of expenditures and resources. In other words, the closer the economy conforms to a free market, the closer it comes to a optimal distribution of wealth. In the light of the social problems, revealed in social surveys of the urban working classes at the end of the 19th century, this scientific justification of laissez-faire contributed to the new paradigm's success as it supported the status quo on non-political grounds. Despite steady growth, increases in real incomes from 1873-1900, and social policies which somewhat relieved the conditions of the working class and the poor, poverty among the producers of the country's wealth was still incredible.

The outstanding neo-classicist, Alfred Marshall, deviated somewhat from his contemporary colleagues because he used marginal utility analysis in his economic works only to a certain degree, and did not withdraw himself from political issues. He explicitly saw widespread poverty as a major problem, which he believed could be solved with the help of sound economics. In this effort he reaffirmed and extended the classical tradition of Adam Smith by showing a relationship between a free enterprise 
economy and the economic well-being of society. Even though he identified the current poverty within the unjust economic structure, he concluded that reforms of the economic system and state interventions would not alleviate poverty but make the problem worse. Only a free enterprise system, supported by economic chivalry and public education, would gradually bring wealth to more people. He derived his optimistic view from marginal utility analysis as well historical studies that supported his view of the slow but gradual betterment of the condition of the working class and the poor. Marshall clearly stood in Smith's tradition as he shared the classical theorist's view of the positive effects of an unregulated economy. However, whereas Smith explicitly stated the idea of general abundance, Marshall was more cautious in making such a broad judgment. He did not promise general abundance but wanted to help with his economic theory "to discover how far it is possible to open up to all the material means of a refined and noble life." Thus, the scope of the idea of general abundance became limited with the neo-classical school, even though it was revitalized after Ricardo's pessimism.

As shown for the classical period, neo-classical economics failed to transform into policy its idea of how abundance for the majority of the people could be achieved--by not intervening in the free market. Caused by the breakdown of social ties which, in particular, put strain on cities, and the gain of political power of the working class through trade unions and the Labour Party, the British governments passed legislation that introduced a collective welfare system and improved the work- 
ing and housing conditions of the working class and the poor at the end of the 19th and the beginning of the 20th century. This legislation, despite its first small effects, marked the final break with laissez-faire policies in regard to social welfare. The state recognized its responsibility for the well-being of its people, and, subsequently, abandoned the neo-classicists' belief in the benevolent powers of free enterprise. This trend was enforced and accelerated in the inter-war period.

During the 1920s and the 1930s the British economy encountered unprecedented mass unemployment as result of trade depressions after the First World War and during the Great Depression. The neo-classical assumption of general equilibrium and full employment in a free enterprise system "seemed blatantly to disregard the crucial problem of economic policy" (Deane 1978:177). So the unemployment problem gave way to a new paradigm in orthodox economics-Keynesianism.

After Ricardo, Keynes is the second theorist for whom it was possible to show a direct influence of the economic structure on the economist's theorizing. In all the other cases such an influence certainly exists, too. However, it is less obvious and specific. Smith shared the widely held optimism of his time and saw an optimistic future for the nation and its people. This optimism and structural changes that endangered the social order led him to reinterpret acquisitive behavior as harmonious interest. Marshall, in light of the poverty problem at his time declared that his major aim was to solve this problem. He backed his mathematical analysis with historical inquiries 
and concluded that a free-enterprise system would gradually work toward the betterment of people's living conditions.

Keynes brought the focus of economics back to macroeconomic questions by developing a model which showed that effective demand determines the national income and the amount of unemployment. He demonstrated that the neo-classical general equilibrium assumptions are only applicable for boom years during the business cycles, and, hence, that the state had to intervene in the economy in order to promote economic growth and prosperity by enhancing the propensity to consume and the inducement to invest. His concrete policy prescriptions were countercyclical budgets including deficit spending, a progressive income tax, low interest rates, the issuance of public loans, and public work programs. As Keynes's theories became the dominant paradigm in orthodox economics in the 1940s, the belief in laissez-faire was abandoned for the first time. General abundance would not come automatically but was only possible with governmental help, so went the new conviction.

Keynes's policy prescriptions gradually became the policies of British governments. While the economic and social policies during the 1920 s and 1930 s were inconsistent in regard to economic theories, Keynes's ideas were fully embraced after the Second World War. "... the myth of laissez-faire died hard in Britain ..." (Holmes 1976:201). Keynes was the first economist whose policy recommendations in regard to general abundance were actually followed by governments. 
In the mid-1970s the Keynesian embrace came to an end. After almost three decades of unprecedented growth the economic boom broke down in the mid-1970s and again in the late 1970s after decisions of the OPEC to drastically increase oil prices. This was followed by tremendous inflation rates for which Keynes and his followers did not have answers. Keynesianism, already in decline in economics since the mid-1960s, subsequently lost its status as dominant orthodoxy, and became discredited in political practice as well. Two new schools of economic thought took over: monetarism, which became dominant from the mid-1970s until the early 1980s, and new classical macroeconomics, which gained dominant status in the early 1980s. Both schools were warm-ups of neo-classical economic thought rather than radical innovations. As had their neo-classical predecessors, they praised laissez-faire and the selfcorrecting mechanisms of the market.

In light of stagflation, the British government embraced these new, preKeynesian ideas and dropped Keynes's policy recommendations. Of course, a radical U-turn from a strongly regulated economy to complete laissez-faire was not possible, but governments, especially from 1979 onward, reduced state interventions and state spending drastically, and explicitly put their policies on monetarist grounds.

In the mid-1980s the Keynesian school re-emerged as "New Keynesianism" and integrated some further assumptions and models in its economic thought. By and large the school followed old Keynesian ideas. With the emergence of new Keynesianism, orthodox economics became split in the mid-1980s. Politicians had the choice between 
two competing schools and clearly followed the non-Keynesian policy prescriptions until now. Despite the recent victory of the traditionally pro-Keynesian Labour Party, Keynesianism does not seem likely to become the fashion again in the next few years.

The above analysis of the idea of general abundance in its socio-historical setting supports Lyotard's thesis that the capitalist metanarrative is in decline; in economic thought, in social and economic policies, and in economic reality. As I have shown, Adam Smith explicitly promised that a free enterprise system would enrich the nation and its people. He was the only one of the examined theorists that was so bold. All his successors were much more cautious. Besides Ricardo, who more or less denied the possibility of general abundance and the first for whom a decline of the idea of general abundance can be seen, the economic schools after Smith only implicitly stated the idea by examining the ways in which the economy works best and how full employment can be achieved. For the neo-classicists and Marshall as for the monetarists and the new classicists, a general equilibrium, i.e. economic growth and full employment, will be the result of a market left to itself. Whereas Marshall surely intended to enrich all people with the help of economic theory, he was not sure to what extent this would be possible. His new classical school successors followed the apolitical stance of the neoclassical school. Beyond the statement that free competition will automatically lead to full employment, they did not seem to be concerned about questions of general welfare but with developing sound economic theory. The monetarists took a more political stance and at least seemed to be concerned to provide a theory that would be applicable 
in politics. However, statements of general abundance cannot be found. Keynes had rejected the laissez-faire approach and saw state interventions as necessary in order to achieve full employment and a more equitable distribution of incomes and wealth. $\mathrm{He}$ seemed to have a firm belief in the possibility of general abundance if government would just follow his recommendations. Therefore, he probably came close to Smith in his conviction that general abundance was possible. The new Keynesians followed Keynes in demanding state interventions as means of economic growth and justice; however, so far they have not come up with a generally accepted theory. In contrast to Keynes and in light of the failure of Keynesian thought in the 1970s they seem rather confused about what kind of policies to recommend. They appear to have lost any conviction of the possibility of sustained economic growth and full employment. Applying the same models as the new classical school, these two groups are hard to distinguish, and only the new Keynesians' pledge for social justice shows the roots underlying their theory. It can be concluded that after Smith, and with the exception of Keynes, who constituted the last stronghold believing that wealth for everybody would be possible, the idea of general abundance in economics is in decline. Currently neither laissez-faire nor state intervention seems to be remedies to enrich the people.

The strong downward trend of the idea since the 1970s is striking. If one were to rank the different schools and theorists in regard to their belief in the possibility of general abundance, I would suggest an order as follows: Smith is clearly at the top as he believed and stated that wealth for everybody will certainly come. Keynes, who was 
convinced of his own theory, follows him closely. The next theorist would be Marshall, who wanted to eliminate poverty but was not convinced to what degree this would be possible. These are the only theorists that believed in the possibility of general abundance, all the others just created theories intended to create the best situation for growth and full employment. I think that Ricardo, despite his pessimistic outlook, was still more convinced of the possibility of general abundance than the three schools that emerged since the 1970s. I would argue that the new classicals are at the bottom of the ranking list, as they were not really concerned about political and social issues. Between Ricardo and this school are the monetarists and the new Keynesians, located at about the same level. Both schools are concerned with growth and the Keynesians also about social issues, and both seem to be disillusioned about the possibility of steady growth, full employment, and social justice.

One can only speculate about the reasons for the not outspoken, however, clear abandonment of the promise of wealth for everybody in economic theory. The inquiry above indicates some arguments. The best hunch is that the economists dropped the promise in light of economic realities. Ricardo witnessed population growth that did not allow economic progress. Marshall had to realize that the social distress in his country was so widespread that it was not certain to what extent a free market system would enrich people despite steady growth. The three schools that emerged in the 1970s and 1980s had witnessed three decades of enormous economic growth plus farreaching governmental interventions that were intended to eliminate poverty and to 
redistribute wealth. The data showed these ideals could not be reached, despite promising political and economic conditions

From this background, I think, it is justified to conclude that economic development and the development of social and economic policies supported the decline of the capitalist metanarrative in economic theory. This finding shows the fruitfulness of examining Lyotard's thesis within the sociology of knowledge. This approach enabled me to look beyond the mere development of the idea of general abundance in economic theory, and to locate its decline within the economic and political environment.

As I have shown, from 1796 onward, the British government abandoned laissez-faire and gradually introduced policies that regulated the economy in relation to the welfare of its people. Especially in the last decades of the 19th and the beginning of the 20th century, much social legislation was introduced. After the Second World War, laissez-faire was officially given up by introducing a social welfare system and fully embracing Keynesian policy recommendations. Thus, since the late 18 th century, there had been a constant growth of economic and social policies intended to alleviate poverty and improve the living and working situation, and to come closer to the promise of wealth for everybody. However, poverty kept its level despite the increasing efforts to eliminate it. Overall, rising living standards, and an enrichment of the upper two thirds of the population cannot be denied, but the lower third of the population constantly was left out of material progress. Especially disappointing in this regard was the failure of Keynesianism after laissez-faire was officially dropped after 1945. This 
situation, the failure of both laissez-faire and Keynesian economics to create general abundance, Lyotard seemed to have had in mind when he said: "the "crises of 1911 and $1929^{\prime}$ refute the doctrine of economic liberalism, and the 'crisis of 1974-79' refutes the post-Keynesian modification of that doctrine." In contrast to Lyotard, this thesis suggests that it was not the economic crises that refuted the doctrines, but the history of long-term economic development coupled with social and economic policies. The recurrent crises in capitalism only reinforced and accelerated the overall patterns and tendencies and so led to a break with, until then, prevalent policies.

British governments always deviated from the laissez-faire recommendations of the classical and neo-classical economists. Widespread economic and social distress of the people challenged the notion of a self-regulating market and promoted state intervention in the economy. The recessions of the 1920s and 1930s were the final events that put the lid on laissez-faire. This doctrine was abandoned in economic theory as well as in politics since the Second World War. Keynesian state intervention took its place and promised to fulfill the capitalist metanarrative. However, Keynes's recommendations did not succeed in enriching everybody. In light of the already recognizable failure of Keynes in the 1960s, the economic recessions of the 1970s led to a comeback of laissez-faire. State interventions in the economy that were steadily increasing since the late 18 th century until the mid-1970s were reduced for the first time. As the general economic development and the economic situation of the people apparently did not seem to differ significantly with or without state interventions, this was the logical step. 
As shown, Keynes was optimistic. He believed in the positive effects of his policy recommendations. It is important that he not only demanded policies that would lead to full employment, but beyond this he argued that income and wealth needed to be redistributed from rich to poor. This did not happen to the necessary extent. The question is why?

In the 1970s distributional conflicts were a major factor that caused the recession of 1973-74, and hence, the conservative reversion to pre-Keynesian economic and social policies. Apparently, richer people were not willing to pay for the abundance of everyone. Peden (1985:232-233) supports this view:

The fundamental stumbling block is an unwillingness on the part of the taxpayers to vote for the kind of transfer of incomes which would confer significant increases in social security benefits. Survey evidence ... has suggested that 74 per cent of the electorate would be prepared to pay an extra penny in the pound in income tax to help the poorest members of society. However, only 34 per cent would definitely be prepared to pay an extra $5 p$ in the pound (...). There is, therefore, some support for increase measures to help the poorest members of society, but not to a degree which would interfere significantly with the personal consumption of the majority.

Redistribution is the crucial issue in regard to general abundance. In light of the analysis above, it seems that what happened in the 1970s and after was that the Labour Party and Keynesian economists became disillusioned about the possibilities of general welfare, which did not seem possible without serious redistributional efforts. Recognizing that this could not be realized, the conservatives stepped into the ideo- 
logical vacuum of the Left. Despite the apparent social distress that was followed by laissez-faire policies, these actions were justified as the conservatives argued that they had applied Keynes for over two decades, but that these ideas apparently failed. Therefore, the only possibility would be to go back to the old policies. Until now the Left has not found satisfying answers to this predicament. That the recent Labour victory that does not seem to presage a return to Keynesian policies emphasizes this.

As mentioned at the beginning of this thesis, the function of metanarratives is to legitimize social and political institutions and practices. As Lyotard (1993a[1979]) pointed out, science especially relied upon metanarratives. Given Lyotard is right, with the decline of, especially, the metanarrative of emancipation and the speculative, Hegelian metanarrative, science lost its legitimation. Lyotard argued that this delegitimation of science had two effects: performativity and paralogy. Both are seen as new sources of legitimation. Performativity is "the optimization ... between input and output" (Lyotard 1993a[1979]:11). That means that science is not searching for truth any more but for the optimal performance of systems. Paralogy refers to a science that is not unified under one paradigm any more, but is characterized by dissent and a multitude of paradigms. Consensus is not possible as it "does violence to the heterogeneity of language games" which are the prevalent mode of postmodern scientific discourses (Lyotard 1993a[1979]:XXV):

Postmodern science-by concerning itself with such things as undecidables, the limits of precise control, conflicts characterized by incomplete information, 'fracta', catastrophes, and pragmatic paradoxes-is 
theorizing its own evolution as discontinuous, catastrophic, nonrectifiable, and paradoxical. ... It is producing not the known, but the unknown. (Lyotard 1993a[1979]:60)

The examination of the state of economics since the 1970s fits into this analysis As I have shown, the idea of general abundance is in decline in economic theory. That means that economists withdrew themselves from the metanarrative that legitimated their profession. Performativity and paralogy stepped in as new legitimating mechanisms. By abandoning the promise of wealth for everybody, economists gave up their search for truth of how to fulfill this promise. Nowadays they merely try to determine how one can maximize economic output and minimize input at the same time, in other words, they are trying to determine optimal performance of the economic system. Furthermore, there is no consensus any more on how to reach this optimal performance. The contemporaneous existence of the new classical school and the new Keynesian school stand for what Lyotard calls paralogy. In this respect the developments in economics since the 1970s are logical consequences of the decline of metanarratives. 
References

Addison, Paul. 1977. The Road to 1945. London: Quartet.

Asimakopulos, Athanasios. 1991. Keynes's General Theory and Accumulation.

Cambridge: Cambridge University Press.

Barnes, Dudley. 1994. "Population, migration, and regional development, 1870-1939," Pp. 29-61 in Roderick Floud and Donald McCloskey (eds.), The Economic History of Britain since 1700. Vol. 2. Cambridge: Cambridge University Press.

Black, R. D. Collison, A. W. Coats, and Craufurd D. W. Goodwin (eds.). 1973. The Marginal Revolution in Economics. Interpretation and Evaluation. Durham, NC: Duke University Press.

Blaug, Mark. 1958. Ricardian Economics. A Historical Study. New Haven, CT: Yale University Press.

Blaug, Mark. 1963. "The Myth of the Old Poor Law and the Making of the New." Journal of Economic History 23:151-184.

Blaug, Mark. 1964. "The Poor Law Report Reexamined." Journal of Economic History 24:229-245.

Blaug, Mark. 1968. Economic Theory in Retrospect. Homewood, IL: Richard D. Irwin.

Blaug, Mark. 1973. "Was there a Marginal Revolution?" Pp. 3-14 in R. D. Collison Black, A. W. Coats, and Craufurd D. W. Goodwin (eds.), The Marginal Revolution in Economics. Interpretation and Evaluation. Durham, NC: Duke University Press.

Bleaney, Michael. 1985. The Rise and Fall of Keynesian Economics. An Investigation of its Contribution to Capitalist Development. New York, NY: St. Martin's Press.

Breit, William, and Roger L. Ransom. 1971. The Academic Scribblers. American Economists in Collision. New York, NY: Holt, Rinehart, and Winston.

Broadberry, Steven. 1994. "Employment and Unemployment," Pp. 195-220 in Roderick Floud and Donald McCloskey (eds.), The Economic History of Britain since 1700. Vol. 3. Cambridge: Cambridge University Press. 
Burtt, Everett J. 1972. Social Perspectives in the History of Economic Theory. New York, NY: St. Martin's Press.

Cairncross, Sir Alexander. 1994a. "Economic policy and performance, 1945-1964," Pp. 32-66 in Roderick Floud and Donald McCloskey (eds.), The Economic History of Britain since 1700. Vol. 3. Cambridge: Cambridge University Press.

Cairncross, Sir Alexander. 1994b. "Economic policy and performance, 1964-1990," Pp. 67-94 in Roderick Floud and Donald McCloskey (eds.), The Economic History of Britain since 1700. Vol. 3. Cambridge: Cambridge University Press.

Caravale, Giovanni, and Domenico A. Tosato. 1980. Ricardo and the Theory of Value Distribution and Growth. London: Routledge.

Chambers, J. D. 1961. The Workshop of the World. British Economic History from 1820 to 1880. London: Oxford University Press.

Colander, David. 1988. "The evolution of Keynesian economics: from Keynesian to New Classical to New Keynesian," Pp. 92-100 in Omar F. Hamouda and John N. Smithin (eds.), Keynes and Public Policy After Fifty Years. Volume I: Economics and Policy. New York, NY: New York University Press.

Collins, Robert M. 1981. The Business Response to Keynes, 1929-1964. New York, NY: Columbia University Press.

Connor, Steven. 1989. Postmodernist Culture. An Introduction to Theories of the Contemporary. Cambridge, MA: Blackwell Publishers.

Court, W. H. B. 1965. British Economic History, 1870-1914. Commentary and Documents. Cambridge: Cambridge University Press.

Crafts, Nick. 1994. "The industrial revolution," Pp. 44-59 in Roderick Floud and Donald McCloskey (eds.), The Economic History of Britain since 1700. Vol. 1. Cambridge: Cambridge University Press.

Crouzet, François. 1982. The Victorian Economy. New York, NY: Columbia Universiyy Press.

Deane, Phyllis. 1965. The First Industrial Revolution. Cambridge: Cambridge University Press.

Deane, Phyllis. 1978. The Evolution of Economic Ideas. Cambridge: Cambridge University Press. 
Deane, Phyllis, and W. A. Cole. 1967. British Economic Growth. 1688-1959. Trends and Structure. Cambridge: Cambridge University Press.

Denzin, Norman K. 1986. "Postmodern Social Theory." Sociological Theory 4:194204.

Dietz, Frederick C. 1949. An Economic History of England. New York, NY: Henry Holt.

Dobb, Maurice. 1973. Theories of Value and Distribution since Adam Smith. Ideology and Economic Theory. Cambridge: Cambridge University Press.

Dow, Sheila C. 1988. "What happened to Keynes's economics?" Pp. 101-110 in Omar F. Hamouda and John N. Smithin (eds.), Keynes and Public Policy After Fifty Years. Volume I: Economics and Policy. New York, NY: New York University Press.

Dumont, Louis. 1986. Essays on Individualism. Modern Ideology in Anthropological Perspective. Chicago, IL: University of Chicago Press.

Eatwell, John. 1985. "Keynes, Keynesians, and British Economic Policy," Pp. 61-76 in Harold L. Wattel (ed.), The Policy Consequences of John Maynard Keynes. Armonk, NY: M. E. Sharpe.

Feinstein, Charles. 1991. "A new look at the cost of living, 1870-1914," Pp. 151-170 in J. Foreman-Peck (ed.), New Perspectives on the late Victorian Economy. Essays in Quantitative Economic History, 1860-1914. Cambridge: Cambridge University Press.

Fitzgibbons, Athol. 1995. Adam Smith's System of Liberty, Wealth, and Virtue. The Moral and Political Foundations of the 'Wealth of Nations'. Oxford: Clarendon Press.

Gumbrecht, Hans Ulrich. 1978. "Modern. Modernität, Moderne," Pp. 93-131 in Otto Brunner, Werner Conze, and Reinhart Koselleck (eds.), Geschichtliche Grundbegriffe. Historisches Lexikon zur politisch-sozialen Sprache in Deutschland, Vol. 4. Stuttgart: Ernst Klett Verlag.

Habermas, Jürgen. 1983. "Modernity—An Incomplete Project," Pp. 3-15 in Hal Foster (ed.), The Anti-Aesthetic. Essays on Postmodern Culture. Seattle, WA: Bay Press.

Hall, Peter A. 1989. "Conclusion: The Politics of Keynesian Ideas," Pp. 361-391 in Peter A. Hall (ed.), The Political Power of Economic Ideas. Keynesianism across Nations. Princeton, NJ: Princeton University Press. 
Harris, Seymour E. 1948. The New Economics. Keynes' Influence on Theory and Public Policy. New York, NY: Alfred A. Knopf.

Heilbroner, Robert L. [1953]/1972. The Worldly Philosophers. The Lives, Times, and Ideas of the Great Economic Thinkers. New York, NY: Simson and Schuster.

Heilbroner, Robert L. 1985. The Nature and Logic of Capitalism. New York, NY: W. W. Norton.

Hirschman, Albert. 1977. The Passions and the Interests. Political Arguments for Capitalism before Its Triumph. Princeton, NJ: Princeton University Press.

Hofstadter, Richard. [1944]/1965. Social Darwinism in American Thought. New York, NY: George Braziller.

Hoge, Warren. 1997a, April 22. "The Hard Times of a Coal Town, Ignored in Booming Britain's Vote." The New York Times, pp. Al, A6.

Hoge, Warren. 1997b, April 28. "Britain's 'New' Labor: No Specifics, Few Promises." The New York Times, pp. A1, A6.

Hoge, Warren. 1997c, May 1. "Major or Blair? British Will Choose in an Election Today." The New York Times, p. A6.

Hoge, Warren. 1997d, May 2. "Britons Back Labor Party; Conservatives Are Routed After 18 Years Of Control." The New York Times, pp. Al, A8.

Hollander, Samuel. 1979. The Economics of David Ricardo. Toronto: Toronto University Press.

Holmes, Graeme M. 1976. Britain and America. A Comparative Economic History, 1850-1939. Newton Abbot: David \& Charles.

Hoover, Kevin D. 1988. The New Classical Macroeconomics. A Sceptical Inquiry. Oxford: Basil Blackwell.

Howey, Richard S. 1973. "The Origins of Marginalism," Pp. 15-36 in R. D. Collison Black, A. W. Coats, and Craufurd D. W. Goodwin (eds.), The Marginal Revolution in Economics. Interpretation and Evaluation. Durham, NC: Duke University Press.

Howlett, Peter. 1994. "The wartime economy, 1939-1945," Pp. 1-31 in Roderick Floud and Donald McCloskey (eds.), The Economic History of Britain since 1700. Vol. 3. Cambridge: Cambridge University Press. 
Hutchison, Terence W. 1973. "The 'Marginal Revolution' and the Decline and Fall of English Classical Political Economy," Pp. 176-202 in R. D. Collison Black, A. W. Coats, and Craufurd D. W. Goodwin (eds.), The Marginal Revolution in Economics. Interpretation and Evaluation. Durham, NC: Duke University Press.

Hutchison, Terence W. 1978. On Revolutions and Progress in Economic Knowledge. Cambridge: Cambridge University Press.

Huyssen, Andreas. 1986. "Mapping the Postmodern." New German Critique 33:5-52.

Ibrahim, Youssef M. 1997, April 29. "Britain '97: Rich, Poor and a Little in Between." The New York Times, pp. Al, C4.

Issawi, Charles. 1978. "The 1973 oil crisis and after." Journal of Post Keynesian Economics 2:3-26.

Jay, Martin. 1991. "Habermas and Modernism," Pp. 98-1 10 in Ingeborg Hoesterey (ed.), Zeitgeist in Babel. The Postmodernist Controversy. Bloomington, IN: Indiana University Press.

Johnson, Christopher. 1991. The Grand Experiment. Mrs. Thatcher's Economy and How It Spread. Boulder, CO: Westview Press.

Johnson, Christopher. 1994. "The welfare state," Pp. 284-317 in Roderick Floud and Donald McCloskey (eds.), The Economic History of Britain since 1700. Vol. 3. Cambridge: Cambridge University Press.

Jordan, Bill. 1981. Automatic Poverty. London: Routledge.

Keynes, John Maynard. [1926]/1972. "The End of Laissez-Faire," Pp. 272-294 in John Maynard Keynes, Collected Writings, Vol. IX. London: Macmillan.

Keynes, John Maynard. [1930]/1971. "A Treatise on Money," in John Maynard Keynes, Collected Writings, Vol. V-VI. London: Macmillan.

Keynes, John Maynard. [1930]/1972. "Economic Possibilities for Our Children," Pp. 321-332 in John Maynard Keynes, Collected Writings, Vol. IX. London: Macmillan.

Keynes, John Maynard. [1933]/1959. "The Means to Prosperity". Pp. 9-41 in Economica Books on Economics, Politics and Business. The Means to Prosperity. Buffalo, NY: Smith, Keynes \& Marshall. 
Keynes, John Maynard. [1936]/1965. The General Theory of Employment, Interest, and Money. New York, NY: Harcourt, Brace \& World.

Kuhn, Thomas S. [1962]/1996. The Structure of Scientific Revolutions. Chicago, IL: University of Chicago Press.

Laider, David. 1981. "Monetarism. An Interpretation and an Assessment." Economic Journal 91:1-28.

Lekachman, Robert. 1966. The Age of Keynes. New York, NY: Random House.

Lindert, Peter H. 1994. "Unequal living standards," Pp. 357-386 in Roderick Floud and Donald McCloskey (eds.), The Economic History of Britain since 1700. Vol. 1 . Cambridge: Cambridge University Press.

Luhmann, Niklas. 1992. Beobachtungen der Moderne. Opladen: Westdeutscher Verlag.

Lyotard, Jean-François. [1979]/1993a. The Postmodern Condition: A Report on Knowledge. Minneapolis, MN: University of Minnesota Press.

Lyotard, Jean-François. [1982]/1993b. "Answering the Question: What is Postmodernism?" Pp. 71-82 in Jean-François Lyotard, The Postmodern Condition: A Report on Knowledge. Minneapolis, MN: University of Minnesota Press.

Lyotard, Jean-François. [1988]/1993c. The Postmodern Explained. Correspondence 1982-1985. Minneapolis, MN: University of Minnesota Press.

MacKinnan, Mary. 1994. "Living standards, 1970-1914," Pp. 265-290 in Roderick Floud and Donald McCloskey (eds.), The Economic History of Britain since 1700. Vol. 2. Cambridge: Cambridge University Press.

Maloney John. 1985. Marshall, Orthodoxy and The Professionalisation of Economics. Cambridge: Cambridge University Press.

Malthus, Thomas Robert. [1789]/1960. An Essay on the Principles of Population, as It Affects the Future Improvements of Society. New York, NY: The Modern Library.

Marshall, Alfred. [1890]/1961. The Principles of Economics. London: Macmillan.

Marshall, Alfred. 1925. "A Collection of Articles, Reviews, Addresses, and Letters," in Arthur Cecil Pigou (ed.), Memorials of Alfred Marshall. London: Macmillan 
Marx, Karl, and Friedrich Engels. [1846]/1961. "From German Ideology," Pp. 197-216 in Erich Fromm, Marx's Concept of Man. New York, NY: Frederick Ungar.

Milgate, Murray, and Shannon C. Stimson. 1991. Ricardian Politics. Princeton, NJ: Princeton University Press.

O'Brien, Denis Patrick. 1975. The Classical Economists. Oxford: Clarendon Press.

Peach, Terry. 1993. Interpreting Ricardo. Cambridge: Cambridge University Press.

Peden, G. C. 1985. British Economic and Social Policy. Lloyd George to Margaret Thatcher. Oxford: Philip Allan.

Preglau, Max. 1995. "Postmoderne Soziologie." Pp. 237-280 in Julius Morel (ed.), Soziologische Theorie. Abriss der Ansätze ihrer Hauptvertreter. München: R. Oldenbourg Verlag.

Preston, Nathaniel Stone. 1967. Politics, Economics, and Power. Ideology and Practice Under Capitalism, Socialism, Communism, and Fascism. London: Macmillan Company.

Pribram, Karl. 1983. A History of Economic Reasoning. Baltimore, MD: John Hopkins University Press.

Ricardo, David. [1815]/1951. An Essay on the Influence of a Low Price of Corn and the Profits of Stock. Cambridge: Cambridge University Press.

Ricardo, David. [1817]/1951. On the Principles of Political Economy and Taxation. Cambridge: Cambridge University Press.

Richardson, Harry W. 1967. Economic Recovery in Britain, 1932-39. London: Macmillan.

Robbins, Lionel Charles. [1952]/1978. The Theory of Economic Policy in English Classical Political Economy. Philadelphia, PA: Porcupine Press.

Robbins, Lionel Charles. 1963. Politics and Economics. London: Macmillan.

Roderick, Floud. 1994. "Britain, 1860-1914: a survey," Pp. 1-28 in Roderick Floud and Donald McCloskey (eds.), The Economic History of Britain since 1700. Vol. 2. Cambridge: Cambridge University Press. 
Rorty, Richard. 1991. "Habermas and Lyotard on Postmodernity," Pp. 84-97 in Ingeborg Hoesterey (ed.), Zeitgeist in Babel. The Postmodernist Controversy. Bloomington, IN: Indiana University Press.

Smith, Adam. [1759]/1976. The Theory of Moral Sentiments. Oxford: Clarendon Press.

Smith, Adam. [1766]/1976. Lectures on Jurisprudence. Oxford: Clarendon Press.

Smith, Adam. [1776]/1976. An Inquiry into the Nature and Causes of the Wealth of Nations. Oxford: Clarendon Press.

Southall, Humphrey. 1991. "Poor Law statistics and the geography of economic distress," Pp. 180-217 in J. Foreman-Peck (ed.), New Perspectives on the late Victorian Economy. Essays in Quantitative Economic History, 1860-1914. Cambridge: Cambridge University Press.

Stigler, George J. 1965. Essays on the History of Economics. Chicago, IL: University of Chicago Press.

Stigler, George J. 1973. "The Adoption of the Marginal Utility Theory," Pp. 305-320 in R. D. Collison Black, A. W. Coats, and Craufurd D. W. Goodwin (eds.), The Marginal Revolution in Economics. Interpretation and Evaluation. Durham, NC: Duke University Press.

Tobin, James. 1987. Policies for Prosperity. Essays in a Keynesian Mode. Cambridge, MA: MIT Press.

Tomlinson, Jim. 1994. "British economic policy since 1945," Pp. 255-283 in Roderick Floud and Donald McCloskey (eds.), The Economic History of Britain since 1700. Vol. 3. Cambridge: Cambridge University Press.

Treble, John G. 1991. "Perfect equilibrium down the pit," Pp. 218-248 in J. ForemanPeck (ed.), New Perspectives on the late Victorian Economy. Essays in Quantitative Economic History, 1860-1914. Cambridge: Cambridge University Press.

Vattimo, Gianni. 1991. "The End of (Hi)story," Pp. 132-141 in Ingeborg Hoesterey (ed.), Zeitgeist in Babel. The Postmodernist Controversy. Bloomington, IN: Indiana University Press.

Viner, Jacob. 1958. The Long View and the Short. Studies in Economic Theory and Policy. Glencoe, IL: The Free Press. 
Wagner, Peter. 1995. Soziologie der Moderne. Freiheit und Disziplin. Frankfurt: Campus Verlag.

Weir, Margaret. 1989. "Ideas and Politics: The Acceptance of Keynesianism in Britain and the United States," Pp. 53-86 in Peter A. Hall (ed.), The Political Power of Economic Ideas. Keynesianism across Nations. Princeton, NJ: Princeton University Press.

Welsch, Wolfgang. 1987. Unsere postmoderne Moderne. Weinheim: VCH.

Welsch, Wolfgang. 1988. "Einleitung," Pp. 1-43 in Wolfgang Welsch (ed.), Wege aus der Moderne. Schlüsseltexte der Postmoderne-Diskussion. Weinheim: VCH.

Welsch, Wolfgang. 1990. "Gesellschaft ohne Meta-Erzählung?" Pp. 174-183 in Wolfgang Zapf (ed.), Die Modernisierung moderner Gesellschaften. Verhandlungen des 25. Deutschen Soziologentages in Frankfurt am Main 1990. Frankfurt: Campus Verlag.

Winch, Donald. 1973. "Marginalism and the Boundaries of Economic Science," Pp. 5977 in R. D. Collison Black, A. W. Coats, and Craufurd D. W. Goodwin (eds.), The Marginal Revolution in Economics. Interpretation and Evaluation. Durham, NC: Duke University Press. 